\title{
INHERITED STRIKE-SLIP FAULTS AS AN ORIGIN FOR BASEMENT-CORED UPLIFTS: EXAMPLE OF THE KUNGEY AND ZAILISKEY RANGES, NORTHERN TIAN SHAN
}

\author{
Jacob Selander
}

A thesis submitted to the faculty of the University of North Carolina at Chapel Hill in partial fulfillment of the requirements for the degree of Master of Science in the Department of Geological Sciences.

Chapel Hill

2008

Approved by:

Michael Oskin

Kevin Stewart

Drew Coleman 


\begin{abstract}
JACOB SELANDER: Inherited strike-slip faults as an origin for basement-cored uplifts: Growth of the northern Tian Shan, Kyrgyzstan and Kazakhstan (Under the direction of Michael Oskin)
\end{abstract}

Reactivation of strike-slip faults and formation of new faults in the surrounding crust may be a common origin for high-angle reverse faults characteristic of basement-cored uplifts. This relationship is explored here by examining the growth of the Kungey and Zailiskey Ranges, the northernmost of the Kyrgyz and Kazakh Tian Shan. These ranges are cored by the inherited, ENE-striking Kemin-Chilik fault. Range growth in response to the northward propagation of the Tian Shan has taken place along a network of steeply-dipping faults surrounding the Kemin-Chilik fault. Structual relief is recorded by the deformation of a previously planar unconformity separating Paleozoic basement from Neogene strata. Late Quaternary deformation inferred from deformed river terraces is consistent with the longterm pattern of range growth. Interpretations of cross-sectional fault geometries are consistent with predictions from a mechanical model of slip partitioning developed by an obliquely-slipping, steeply-dipping, reactivated fault at depth. 


\section{ACKNOWLEDGEMENTS}

I would like to thank Ray Weldon and Reed Burgette for introducing me to the Tian Shan, and all the members of the 2004 NSF-supported Tian Shan Field Camp for mapping in the western Kungey Range and Kok-Moynok basin. I am especially grateful to my colleagues from the Kyrgyz Institute of Seismology, Cholponbek Ormukov and Kanatbek Abdrakhmatov, for invaluable help both organizing logistics and out in the field. Also thanks to Michael Oskin and Joseph Goode for mapping assistance. 


\section{TABLE OF CONTENTS}

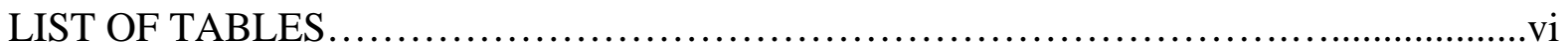

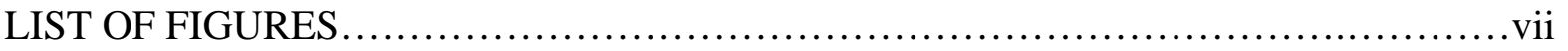

Chapter

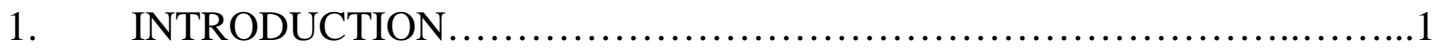

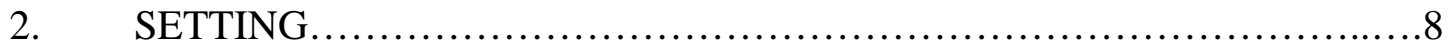

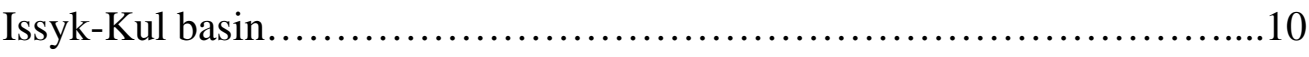

Neogene-Quaternary stratigraphy.....................................11

3. STRUCTURES OF THE KUNGEY AND ZAILISKEY RANGES..............16

Western Kungey Range..............................................16

Central Kungey Range................................................22

Chon-Kemin and Chon-Aksu valleys..................................25

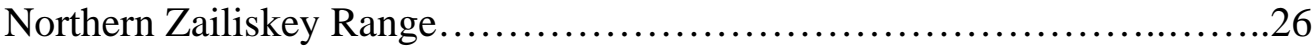

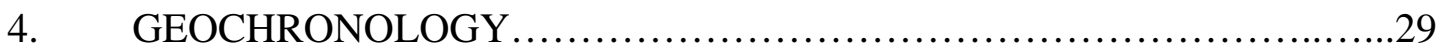

5. LATE QUATERNARY DEFORMATION RATES..........................33

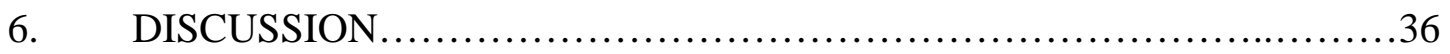

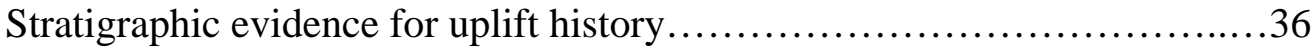

Structural evolution.....................................................

Comparison of long-term and late Quaternary deformation...................46 
The role of strike-slip faulting in shortening of the

northern Tian Shan....................................................47

Implications for the development of high-angle

basement-involved reverse faults.....................................49

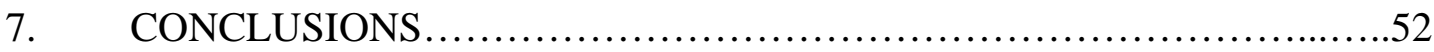

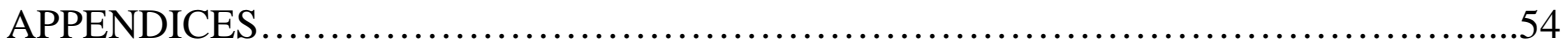

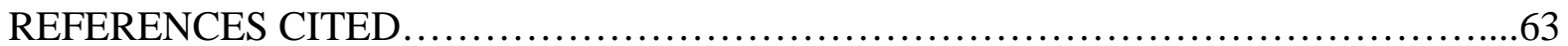




\section{LIST OF TABLES}

Table

1. Morphology and characteristics of major terrace

divisions in the northern Tian Shan.......................................15

2. ${ }^{10}$ Be data for samples taken from terraces

along the Toru-Aygir River............................................32

3. Slip rates and fault data from the Kungey and Zailiskey Ranges..................34 


\section{LIST OF FIGURES}

Figure

1. Reference map of central Asia...........................................4

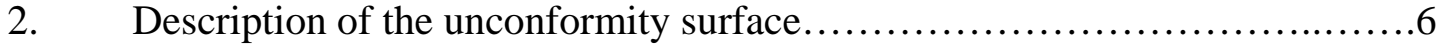

3. Cenozoic stratigraphy of the Kungey Range............................12

4. Detailed Neogene and Quaternary geology of the western Kungey Range..............................................17

5. Aerial photograph of sinistral offset north of Balikche....................19

6. Annotated aerial photograph of sinistral offset northeast of Balikche.........20

7. Fault scarp profiles in the western Kungey Range........................21

8. Detailed Neogene and Quaternary geology of the central Kungey Range..............................................23

9. Fault scarp profiles in the central Kungey Range...........................24

10. Neogene and Quaternary geology of the northern Zailiskey Range............27

11. Fault scarp profiles near Chilik, Kazakhstan............................28

12. $\quad{ }^{10}$ Be depth profiles.........................................................

13. Summary of late Quaternary fault slip rates in the northern Tian Shan...................................................34

14. Schematic block diagram of a positive flower structure.....................39

15. Cross-section interpretation through the western Kungey Range..............40

16. Detail of the Ak-Teke anticline.........................................42

17. Cross-section interpretation through the central Kungey Range...............43 
18. Schematics of fault geometries surrounding

a sinistral strike-slip fault......................................................48

19. Slip partitioning model for the Kungey Range..................................51

PLATE 1: $\quad$ Neogene and Quaternary geology of the western Kungey Range and Toru-Aygir River valley

PLATE 2: Neogene and Quaternary geology of the central Kungey Range 


\section{Introduction}

Basement involved thrust belts (BITB), here defined as belts of shortening characterized by high-angle, reverse fault-bounded uplifts, are common on the margins of many orogenic belts (Tapponnier and Molnar, 1979; Jordan and Allmendinger, 1986; Rogers, 1987; Bump, 2003; Hilley et al., 2005) or plateau “pop-up” style structures (Bilham and England, 2001). Individual "thick-skinned" structures within these deformation belts typically absorb only minor amounts of shortening (Erslev, 1991; Narr and Suppe, 1994), thus significant shortening accommodated in BITB must involve slip on multiple structures. This is in contrast with "thin-skinned" thrust belts, where thrust sheets or wedges are detached from basement that is subducted beneath a gently dipping, long-lived, large-offset thrust fault (e.g. Hubbert and Rubey, 1959; Chapple, 1978; Davis et al., 1983; Burchfiel et al., 1999; Scharer et al., 2004). Though the amount of shortening across BITB is typically low $(<200 \mathrm{~km})$ the rates of deformation in presently active BITB can be a significant portion of the total shortening rate across an orogen (Jordan and Allmendinger, 1986; Abdrakhmatov et al., 1996; Molnar and Ghose, 2000; Meade and Hager, 2001).

Development of BITB requires repeated through-going failure of the basement to initiate new or reactivate pre-existing reverse faults. However, initiation of slip on highangle reverse faults in BITB poses two problems: development of new high-angle reverse faults violates the prediction from Mohr-Coulomb mechanics that thrust faults will form with $\sim 30^{\circ}$ dip (Anderson, 1951) and motion on high-angle structures is kinematically 
unfavorable to absorb shortening (e.g. Sibson, 1985). One explanation for the development of BITB is the re-activation of an older structural grain. Many studies have shown that inherited faults exert a strong influence on the loci of deformation in intracontinental orogens (e.g. Holm and Cloud, 1990; Allen and Vincent, 1997; D’Lemos et al., 1997; Holdsworth et al., 1997; Darby and Ritts, 2002; Bump, 2003; Mouthereau and Lacombe, 2006; Butler et al., 2006; Webb and Johnson, 2006). Inheritance of older structures may be favored where reactivation of pre-existing faults requires significantly less work than initiation of new, optimally oriented faults (Cowie and Scholz, 1992; Scholz, 2002). Pre-existing high-angle faults may also become mechanically favorable when pore fluid pressure within the crust surrounding such faults approaches lithostatic loading and sufficiently decreases friction along the fault surface (Hubbert and Rubey, 1959; Sibson et al., 1988; Hilley et al., 2005). However, both of these conditions cannot explain the generation of new high-angle faults in BITB. Thus, either all faults in these settings are reactivated, mechanically favorable high-angle faults or there exists a poorly understood process that initiates new high-angle reverse faults, despite their mechanical shortcomings.

In this study, we explore the possible role of oblique deformation in the origin of high-angle reverse faults in BITB. Commonly, reverse faults present in BITB are oriented oblique, rather than orthogonal, to overall compression (Tapponnier and Molnar, 1979; Jordan and Allmendinger, 1986; Ding et al., 2004). In regions of complex structural history, a pre-existing structural grain is unlikely to be oriented optimally to absorb compression; nonetheless these weaker areas of crust may be preferentially reactivated (Webb and Johnson, 2006). Re-activation of these high-angle structures at 
depth in a compressional regime can cause deformation to propagate upwards as a partitioned system of reverse and obliquely slipping faults (Molnar, 1992; Bowman et al., 2003). This partitioning can possibly represent a lowest energy condition for motion (Michael, 1990), potentially required for the re-activation of pre-existing faults. Stress conditions at the margins of an orogen may also be critical to this reactivation process. The irregular distribution of topographic loads introduces variations in horizontal stress that could locally change the direction of principal stresses such that strike-slip faulting is locally favored over reverse faulting (Cowgill et al., 2003).

Once initiated or re-activated, strike-slip faults can accommodate shortening in an orogen via transform motion and outward horizontal extrusion of material (Molnar and Tapponier, 1975). Alternatively, major strike-slip faults may be entirely embedded within an orogen, requiring that all slip along the fault must eventually be absorbed by local thickening or shortening structures (e.g. Kirby et al., 2007). Because high-angle strike-slip faults may evolve into oblique-reverse faults with continued deformation (Sibson et al., 1985), the development and overprinting of such faults provides a possible origin of the ubiquitous high-angle reverse faults in BITB. Thus, there may exist a fundamental, but poorly characterized, relationship between strike-slip faults and the propagation of BITB.

To explore the role of inherited strike-slip faults in the formation of high-angle reverse faults, we study the Tian Shan of central Asia (Fig. 1a). The Tian Shan are a BITB formed as a result of Indo-Eurasian convergence (Burtman, 1975; Molnar and Tapponnier, 1975; Tapponnier and Molnar, 1979; Avouac et al., 1993; Abdrakhmatov et al., 2001; Thompson et al., 2002), and are dominated by north-south convergence along 


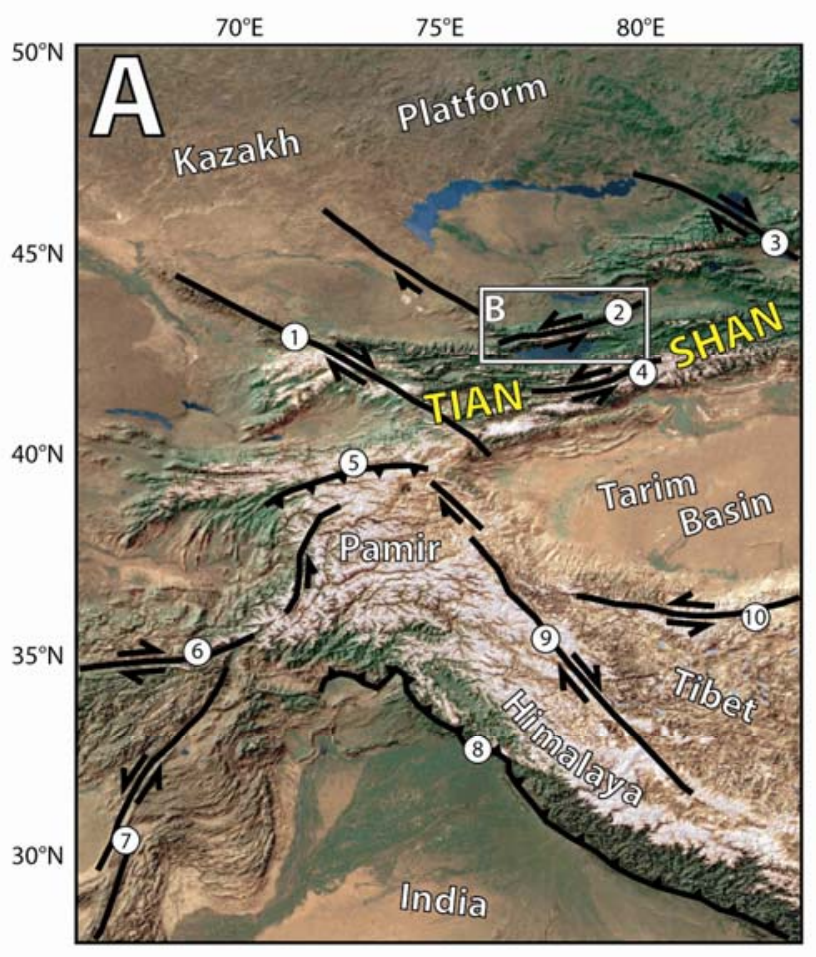

Fault names for A:
(1) Talas-Fergana fault
(6) Herat fault
(2) Kemin-Chilik fault
(7) Quetta-Chaman fault
(3) Dzhungarian fault
(8) Himalayan frontal thrust
(4) Inylchek fault
(9) Karakorum fault
(5) Pamir thrust
(10) Altyn-Tagh fault

Explanation for $A$ and $B$

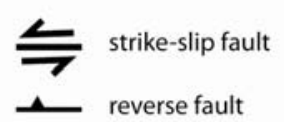

solid where certain dashed where inferred

Cenozoic deposits

Preserved unconformity

surface

Basement

(Paleozoic and older)

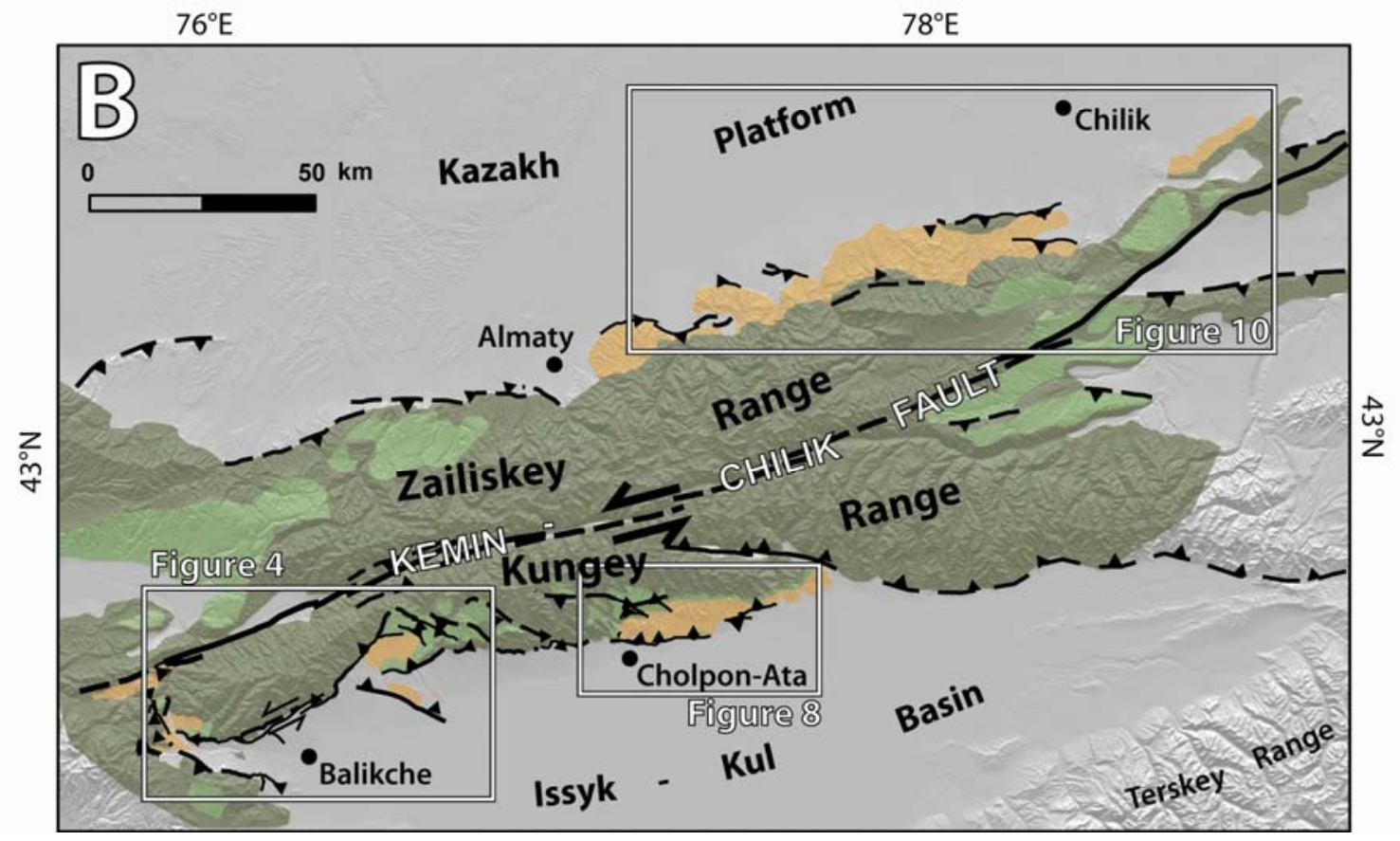


Figure 1. (A) Map of central Asia showing the location of the Tian Shan, highlighting major tectonic provinces and strike-slip faults of the India-Eurasia convergence. Fault locations and names from Molnar and Tapponnier (1975), image courtesy of WSI Earth. (B) Generalized geology of the Kungey and Zailiskey Ranges, northern Tian Shan, noting major structures, Paleozoic basement, and location of preserved Cenozoic deposits. Locations of detailed maps in Figures 3, 7, and 9 are shown. Mapping overlain on shaded relief generated from Shuttle Radar Topography Mission data (Farr et al., 1997).

east-west striking high-angle reverse faults (Abdrakhmatov et al., 1996; Burbank et al., 1999; Korjenkov, 2000; Mikolaichuk et al., 2000; Molnar and Ghose, 2000; Abdrakhmatov et al, 2001; Bullen et al., 2001; Meade and Hager, 2001; Thompson et al., 2002; Bullen et al.,2003; Mikolaichuk et al., 2003; Bowman et al., 2004; Sobel et al., 2006; De Grave et al., 2007; Korjenkov et al., 2007). Strike-slip faulting is also prevalent in the Tian Shan (Figure 1), ranging in scale from the $\sim 600-\mathrm{km}$ long Talas Fergana fault that bisects the entire orogen (Burtman et al., 1996) to somewhat shorter strike-slip faults that are embedded within the orogen (Delvaux et al., 1999; Mikolaichuk, 2000, Buslov et al., 2003). The objective of this study is to determine the role of these embedded strikeslip faults in accommodating north-south shortening and northward propagation of the Tian Shan.

We focus in detail on the example of the Kungey and Zailiskey Ranges in the northern Tian Shan. These ranges are separated by the Kemin-Chilik fault, a 240 km-long inherited, active sinistral fault (Delvaux et al., 1999) (Fig. 1b). Analysis of synorogenic Neogene stratigraphy shows that the Kungey and Zailiskey Ranges formed in response to northward propagation of the Tian Shan. Preservation of a pre-orogenic unconformity as a low-relief upland surface (Fig. 2) provides an unusually extensive structural marker from which we can measure integrated deformation. The temporal evolution of uplift and 


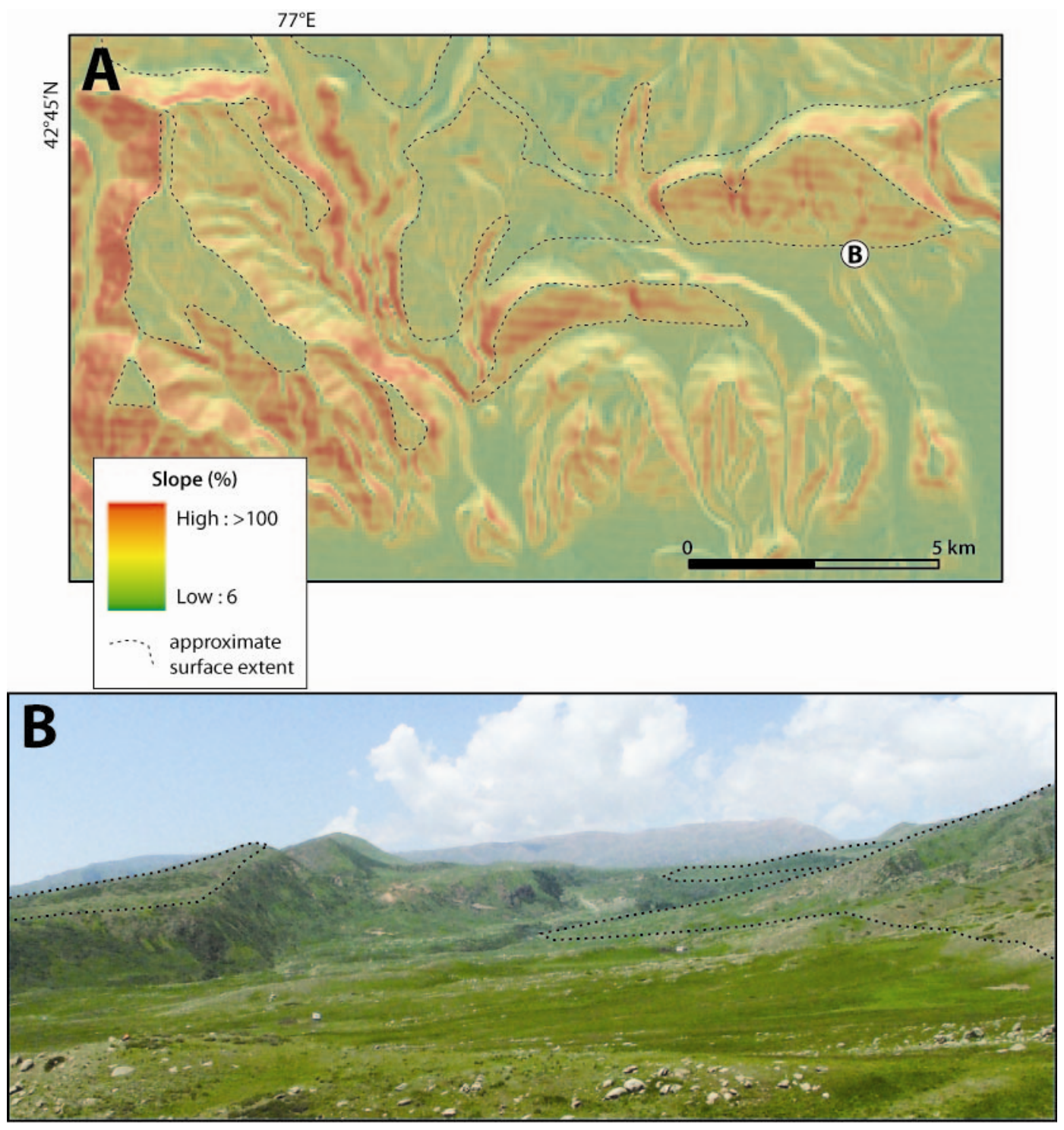

Figure 2. (A) Slope map overlain on a hillshade model showing examples of the preserved unconformity surface present in the central Kungey Range. Approximate extent of the preserved surface is noted. Note that horizontal striping in slope data highlights an artifact common in Shuttle Radar Topography Mission data from this area. (B) Photo taken looking west at point B (location shown in (A)) of the preserved unconformity surface. The extent of the surface is outlined in the foreground; ridgetops in background are also portions of the preserved surface. 
reactivation of structures in building these ranges is inferred from comparison of this deformed marker surface to rates and styles of late Quaternary fault activity. The geometry of faulting at depth is constrained from folding and faulting of the unconformity surface, and from folding of Neogene strata and Quaternary fluvial terraces. Though the Kemin-Chilik fault is inherited, we argue that range growth took place along newly generated, steeply dipping reverse faults emanating from the strike-slip fault at the core of the ranges. The distribution of active shortening shows that range growth occurs via integrated shortening and strike-slip faulting, with gradients in deformation rates that result from trade off between strike-slip and reverse-slip fault systems. These observations are consistent with the development of new high-angle reverse faults in a BITB through interaction of regional compression with a re-activated, obliquely oriented strike-slip fault. 


\section{2. $\quad$ Setting}

The Tian Shan is composed of a series of east-west striking basement uplifts commonly reaching elevations of $5 \mathrm{~km}$ with a maximum of $7 \mathrm{~km}$ in the central portion of the orogen, and is bounded on the north and south by the Kazakh Platform and Tarim Basin, respectively (Fig. 1a). Although 1000-1500 km north of the collisional plate boundary between India and Eurasia, the Tian Shan have been built as a direct result of this collision (Burtman, 1975; Molnar and Tapponnier, 1975; Tapponnier and Molnar, 1979; Avouac et al., 1993) and have absorbed $\sim 200 \pm 50 \mathrm{~km}$ of crustal shortening (Avouac et al., 1993). Current shortening rates for the western Tian Shan are approximately $20 \mathrm{~mm} / \mathrm{yr}$, roughly equal to shortening across the Himalaya and almost half of the total Indo-Eurasian convergence (Abdrakhmatov et al., 1996; England and Molnar, 1997a,b; Larson et al., 1999; Meade and Hager, 2001; Reigber et al., 2001). Fault-plane solutions (Molnar and Ghose, 2000) and sliprate studies (Abdrakhmatov et al., 2001; Thompson et al., 2002) show this shortening is being accommodated via thrust or oblique-slip transpressional motion distributed throughout the western Tian Shan, not confined to its margins.

The basement rocks of the Tian Shan are a part of the Central Asian Orogenic Belt, a series of accreted microcontinents, accretionary wedges, continental margin and volcanic arcs which were sutured onto the edge of the Siberian craton to form the Kazakh Platform from 540 - 250 Ma (Sengor et al., 1993; Mossakovsky et al., 1994; Carroll et al., 2001; Windley et al., 2007). Evidence of minimal Mesozoic tectonism in the western Tian Shan is

preserved as deposition of Jurassic shales in a few minor basins. The Cretaceous and early 
Cenozoic were dominated by erosion, beveling down the Paleozoic rocks to form a quasiplanar erosional surface (Makarov, 1977; Sadybakasov, 1990). This low-relief unconformity surface separates basement from overlying late Cenozoic pre- and synorogenic deposits (Chediya, 1986) and is widely preserved as a relict landform throughout uplifted basement ranges in the Tian Shan (Fig. 2), thus providing an excellent structural and geomorphic marker (e.g. Burbank et al., 1999; Abdrakhmatov et al., 2001; Thompson et al., 2002; Mikolaichuk et al., 2003; Oskin and Burbank, 2005; Sobel et al., 2006; Oskin and Burbank, 2007).

Orogenic growth initiated in the eastern and southern Tian Shan circa 25-20 Ma, based on thermochronologic and magnetostratigraphic studies (Hendrix et al., 1994; Sobel and Dumitru, 1997; Yin et al., 1998; Dumitru et al., 2001; Heermance et al., 2007). Deformation appears to have propagated northwards as a series of east-west striking basement uplifts. Examination of pre-and syn-orogenic stratigraphy and thermochronology from the Kyrgyz Range in the northwestern Tian Shan demonstrate a history of Miocene burial prior to exhumation starting at 11 Ma (Bullen et al., 2001; Bullen et al., 2003; Sobel et al., 2006), consistent with northward propagation into a former foreland basin.

Basement ranges are separated by basins filled with Cenozoic syn-orogenic deposits (Butman, 1975, Burbank et al., 1999; Abdrakhmatov et al., 2001; Thompson et al., 2002). Quaternary deformation is concentrated within these basins where faults and folds deform Cenozoic sedimentary and alluvial deposits. Active shortening structures are often located kilometers from the basement-bounding structures (Thompson et al., 2002). Surface expressions of faults and folded strata define a shallow ramp-style geometry at depth which 
transfers deformation on to steep crustal-scale faults at the range fronts (Molnar et al., 1994; Burbank et al., 1999; Burchfiel et al., 1999; Thompson et al., 2002).

The majority of range fronts and river networks in the Tian Shan contain a regionally correlative suite of alluvial fans and fluvial terraces. Previous studies correlate and group these terraces on the basis of morphology and geomorphic position into four main divisions, Q1, Q2, Q3 and Q4 (Grigorienko, 1970; Makarov, 1977 as cited by Thompson et al., 2002). These terraces and fans provide planar, ideal markers with which to measure modern deformation amount and style across active structures (e.g. Weldon and Sieh, 1985; Avouac et al., 1993; Molnar et al., 1994; Lave and Avouac, 2000; Abdrakhmatov et al., 2001; Thompson et al., 2002).

\subsection{The Issyk-Kul basin}

The Issyk-Kul basin in northeastern Kyrgyzstan is the largest intermontane basin in the Tian Shan ( 230 km east-west and $\sim 80 \mathrm{~km}$ north-south) (Fig. 1b). The basin is deepest along its southern margin, where the south-dipping pre-Cenozoic unconformity surface is overlain by $\sim 4 \mathrm{~km}$ of sedimentary fill (Mikolaichuk, 2000; Buslov et al., 2003). The south side of the basin is bounded by the Terskey Range, where over $7 \mathrm{~km}$ of structural relief has been developed, evidenced by preservation of the unconformity surface at high elevations ( 4 km) within the Terskey Range. The 700 m-deep Issyk-Kul (Kul = lake) with a surface elevation of 1600 m currently occupies the majority of the basin (Buslov et al., 2003).

The Kungey and Zailiskey Ranges are the northernmost ranges of the Tian Shan and bound the northern margin of the Issyk-Kul basin. These ranges are juxtaposed by the historically active north-northeast striking sinistral Kemin-Chilik fault (Delvaux et al., 1999, 2001; Crosby et al., 2007). Fission track studies of the Kungey Range indicate an absence of 
reset ages (DeGrave et al., 2007). This observation, along with the widespread preservation of the pre-Cenozoic unconformity surface at high elevations, supports relatively recent uplift with little incision when compared to the adjacent Kyrgyz Range (Sobel et al., 2006). The margins of the Kungey and Zailiskey ranges are bounded by active fold and thrust belts where deformation is accommodated by slip along north- and south-vergent thrust and reverse faults as well as by slip on obliquely oriented strike-slip faults.

\subsection{Neogene-Quaternary Stratigraphy}

Pre- and syn-orogenic Neogene and Quaternary strata of the northern Tian Shan can be regionally correlated despite facies changes along strike of the range fronts (Fig. 3). Synorogenic strata consist of a wedge of fluvial sediments derived from more southerly portions of the Tian Shan. This wedge is overlain by a coarsening-upward series of sandstones and conglomerates that records erosion of the growing Kungey and Zailiskey Ranges.

The basal Neogene unit is the Kokturpak (Suluterek) formation (Korjenkov, 2000; Mikolaichuk, 2000; Abdrakhmatov et al., 2001; Povolotskaya et al., 2006) which unconformably overlies the Paleozoic basement and varies from 10 to $80 \mathrm{~m}$ in thickness. The base of the Kokturpak Fm. consists of thin paleosols with carbonate nodules, minor gypsiferous sandstones, and thin local lacustrine carbonate deposits. Locally in the western Issyk-Kul basin basal layers of the Kokturpak Fm. are overlain by interbedded red siltstones and sandstones with abundant gypsum beds. Basalts flows present in the Kokturpak Fm. near Toru-Aygir have been dated at $53 \pm 1 \mathrm{Ma}$ (Sobel and Arnaud, 2000). However, the age of its uppermost strata is likely to just predate the onset of foreland basin sedimentation at any given site. 


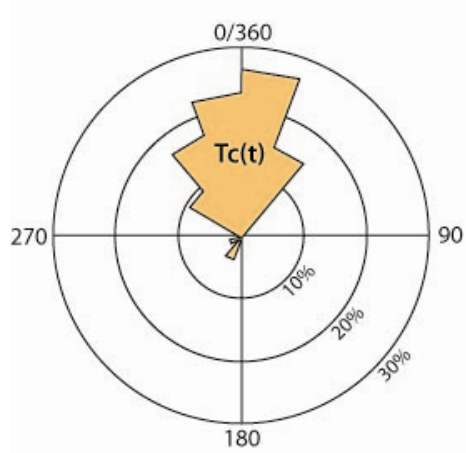

Paleocurrents for the Chu (Terskey) Fm. near ToruAygir

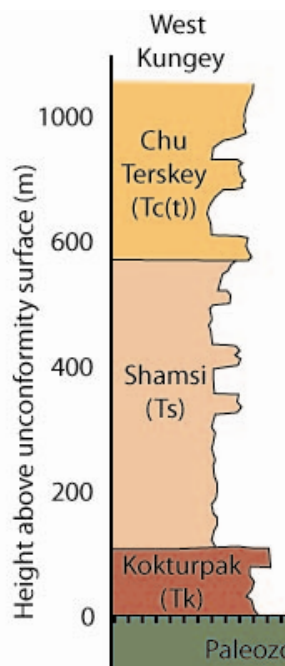

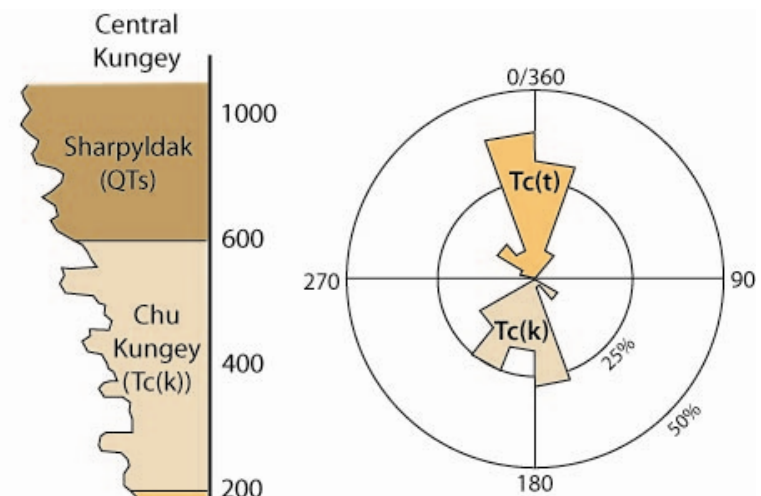

Paleocurrents for the Terskey and Kungey members of the Chu Fm. near Cholpon-Ata

Figure 3. Cenozoic stratigraphy of the western and central Kungey Range front. Thicknesses determined from conformable dip sections and cross-section interpretations. Rose diagrams show paleocurrents from the Chu Fm. near Toru-Aygir $(n=52)$ and near Cholpon-Ata $(\mathrm{n}=68)$. Azimuths measured from cross-bedding exposures and imbricated clasts. See Appendix A for paleocurrent measurements and locations.

A conformable, gradational contact separates the Kokturpak Fm. from the overlying Shamsi Fm. Oldest of the syn-orogenic stratigraphy, the Shamsi Fm. consists of massive red sandy clay units interbedded with paleosols and minor gravel conglomerates. Basal layers contain gypsiferous horizons which become absent higher in the column. Along the southern margin of the Kungey Range, the Shamsi Fm. is absent in the east, thickening to $\sim 500 \mathrm{~m}$ in the west. In adjacent intermontane basins thickness of correlative Shamsi Fm. has been measured at several hundred meters (Abdrakhmatov et al., 2001). Paleomagnetic data from the exposures fringing the nearby Kyrgyz Range places a depositional time of $\sim 12-8 \mathrm{Ma}$ (Abdrakhmatov et al., 2001; Bullen et al., 2001).

The widespread basin-filling unit is referred to as the Chu Fm. (Korjenkov, 2000; Mikolaichuk, 2000; Abdrakhmatov et al., 2001) and locally noted as the Issyk-Kul Fm. (Bowman et al., 2004; Korjenkov et al., 2007). We divide the Chu Fm. into two members 
based on clast lithology indicative of source area. The Terskey member consists of sandstones, gravels and gravel conglomerates interbedded with massive silt and sand layers. Individual clasts include metavolcanic rocks, metasedimentary rocks, gneiss, low-grade schists, and felsic plutonic rocks. Bedded layers display abundant low-angle cross bedding with paleocurrent indicators that support south-to-north transport (Figure 3). On the basis of paleocurrent directions and diversity of clast lithology, the Terskey member is inferred to be syn-tectonic with the growth of the Terskey Range south of the Issyk-Kul basin. The Kungey member of the Chu Fm. is composed of locally derived granitic material forming massive grus layers with interbedded sandstones and gravel conglomerates. Cross-bedding in sandstone and conglomerate layers indicates a north-to-south transport direction (Fig. 3). Flanking the western Kungey Range, the $>600$ m-thick Terskey member of the Chu Fm. conformably overlies the Shamsi Fm. The Kungey member is preserved only locally at the top of the section. In outcrops along the central Kungey Range, as little as $10 \mathrm{~m}$ to as much as $200 \mathrm{~m}$ of the Terskey member conformably overlies the Kokturpak Fm. and is in turn conformably overlain by the Kungey member.

The conglomerates of the Sharpyldak Fm. overlie the Kungey member of the Chu Fm. with a gradational coarsening-upward contact. These conglomerates are composed of locally-derived, dominantly granitic clasts, are $>700 \mathrm{~m}$ thick, and record erosion of the Kungey Range and consequent progradation of coarse material into the Issyk-Kul basin. Where present proximal to the Kungey Range, the Sharpyldak Fm. is purely granitic in composition containing clasts up to $2 \mathrm{~m}$ in diameter supported by a grus matrix. Correlation with Sharpyldak Fm. in other basins places the onset of deposition at mid-Pliocene or $\sim 4$ Ma (Abdrakhmatov et al., 2001). However, because the coarse-grained 
facies of the Sharpyldak Fm. are linked to the uplift and erosion of local source areas, its age may be significantly younger or older locally.

Reconnaissance investigations indicate that the Neogene stratigraphy of the Zailiskey Range consists of similar Kokturpak and Shamsi Fm. equivalents that are overlain by coarser Chu and Sharpyldak Fm. equivalents that record range uplift and erosion. An exposure of a tilted, north-dipping section lying atop the unconformity surface east of Chilik shows that the Kokturpak equivalent is $\sim 80 \mathrm{~m}$ thick, Shamsi equivalent $\sim 400 \mathrm{~m}$ thick, and Chu equivalent $>500$ m thick.

Late Quaternary deposition in the northern Tian Shan is recorded by a regionally correlative, well-preserved suite of fluvial terraces and alluvial fans. Composition of clasts composing these deposits in the northern Issyk-Kul basin is predominantly granitic, reflecting the composition of the Kungey Range source area. These surfaces can be classified using morphology and geomorphic position (Grigorienko, 1970; Makarov, 1977; as cited by Thompson et al., 2002) and additional criteria we define in this study (Table 1). Subdivisions of major terrace groups are defined by surface morphology, pavement development, soil development, and clast characteristics to $50 \mathrm{~cm}$ depth. We divide Q2 into Q2 1 and Q2 2, Q3 into Q3 1 , Q3 2 and Q3 3 , and define recent (likely Holocene) surfaces as Q4. Because $\mathrm{Q}_{2}$ is the most widely preserved terrace and fan deposit, the majority of measurements were made where faults displace its surface. 


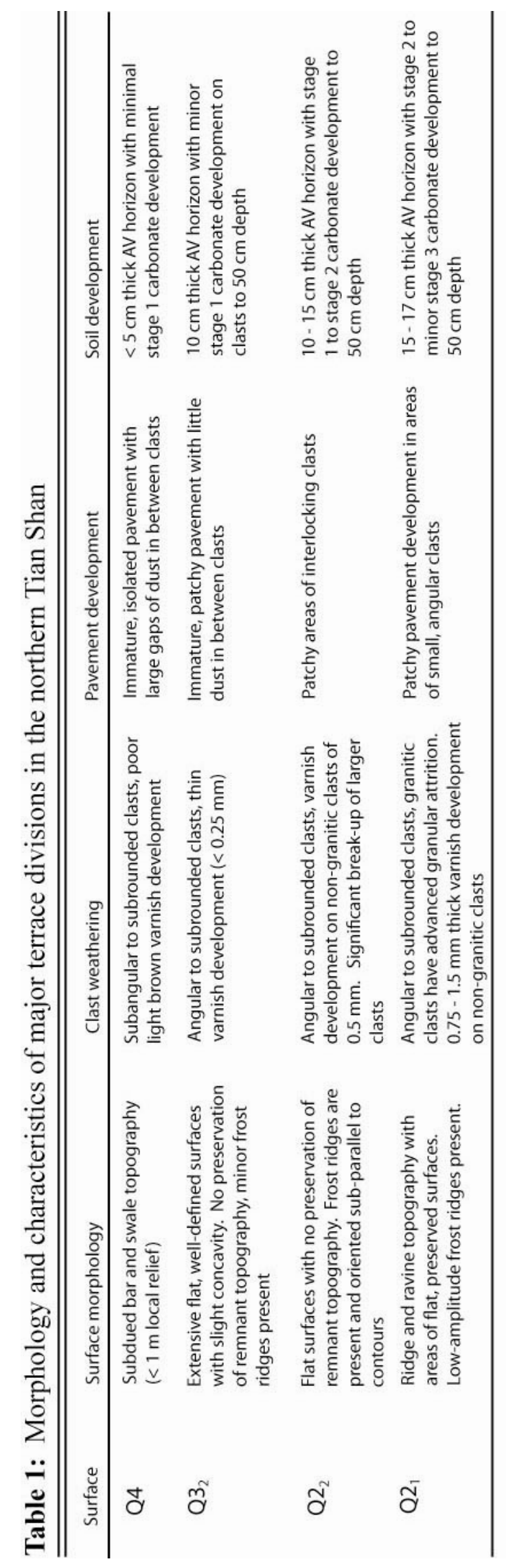




\section{Structures of the Kungey and Zailiskey Ranges}

Neogene and Quaternary geology of the Kungey and Zailiskey Ranges was mapped on aerial photography, LANDSAT imagery, and 1:25,000 topographic maps. Structural measurements were taken in deformed Neogene strata to determine fold and fault geometries. Deformed terrace surfaces were identified; vertical and lateral offsets were measured with a Trimble GeoXT differential GPS to determine displacement.

\subsection{Western Kungey Range}

The western Kungey Range consists of a wedge shaped basement uplift bounded by sinistraloblique faults with reverse faults at its western end (Mikolaichuk, 2000; Delvaux et al., 1999; 2001; Povolotskaya et al., 2006) (Fig. 4 and Plate 1). The unconformity surface has been folded and faulted over the range crest with $>3 \mathrm{~km}$ of structural relief. The northwest side of the range is bounded by the sinistral Kemin-Chilik fault, and the southeast side of the range by the sinistral Toguz-Bulak fault. These faults are linked at the western end of the Kungey Range by a set of reverse faults that bound the intensively deformed Kok-Moynok basin. This basin lies between the Kungey Range and the Kyrgyz Range to the west. A series of east-west striking, south-vergent reverse faults step southward from the eastern end of the Toguz-Bulak fault. The range front also steps south from here to form the central Kungey Range. In this area, at high elevations within the range, additional east- to southeast-striking reverse faults are inferred from offset of the low-relief relict unconformity surface. 


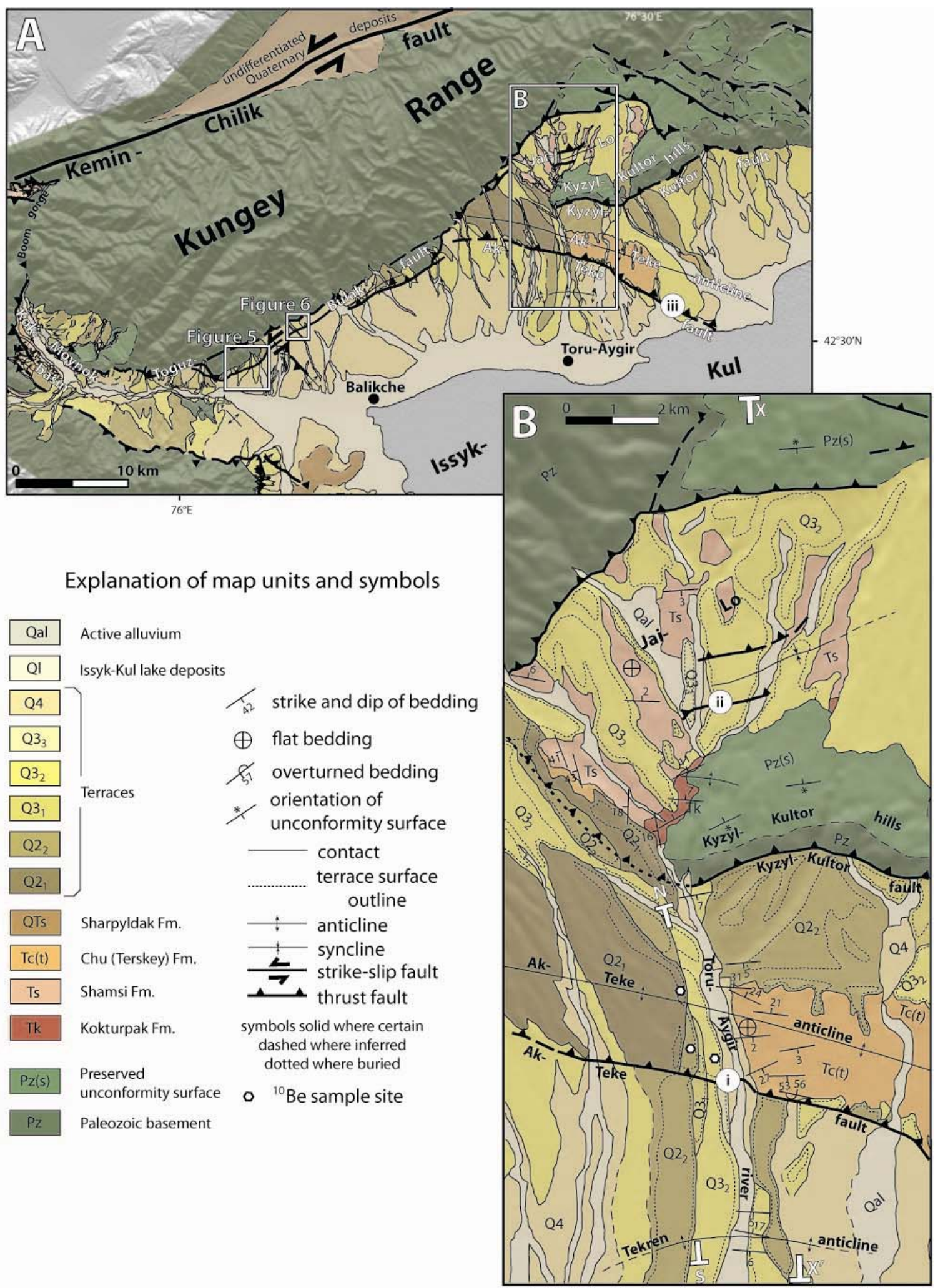


Figure 4. (A) Geologic map emphasizing Neogene and Quaternary strata of the western Kungey Range. See Fig. 1 for map location. Locations of Figs. 5 and 6 shown. Mapping overlain on shaded relief map as in Fig. 1. (B) Detailed Neogene and Quaternary geology of the Toru-Aygir River valley. Locations (i), (ii), and (iii) (in A) are locations of detailed fault scarp surveys, shown in Fig. 6. N-S line notes the location of a long survey profile of the Ak-Teke and Tekren anticlines shown in Fig. 7. X-X' notes the cross-section line in Fig. 15. Due to the density of structural measurements, not all are shown in this figure. See Appendix B for all structural data and locations.

Structures exposed along the Toru-Aygir River reveal a pattern of deformation stepping southward from the Kungey Range (Bowman et al., 2004). In the Ak-Teke hills, along the lower Toru-Aygir River the Chu (Terskey) is deformed into an anticline in the hanging wall of the north-dipping Ak-Teke fault (Korjenkov, 2000; Mikolaichuk, 2000; Bowman et al., 2004; Korjenkov et al., 2007). The Ak-Teke anticline is $\sim 3 \mathrm{~km}$ in width and extends at least $30 \mathrm{~km}$ east-west. The anticline is asymmetric with a backlimb dip of $30^{\circ}$ north, a broad flat crest, and overturned beds in the southern limb where the Ak-Teke thrust fault outcrops at the surface. Morphology and geometry of the fold lead to the interpretation that the Ak-Teke anticline is a fault-propagation fold formed synchronously with slip on the Ak-Teke fault (Suppe, 1983; Suppe and Medwedeff, 1990). North of the Ak-Teke anticline lies the Kyzyl-Kultor basement uplift and the Jai-Lo syncline. The Kyzyl-Kultor hills consist of Paleozoic rocks folded and uplifted along the south-vergent Kyzyl-Kultor fault. The JaiLo syncline deforms both the Paleozoic bedrock and overlying Neogene sediments. Faults rooting into bedrock within the Jai-Lo syncline are responsible for local shortening near the syncline axis.

Figure 5. (A) Aerial photograph of sinistrally offset $\mathrm{Q} 3_{2}$ fan along the Toguz-Bulak fault north of Balikche. Location shown in Fig. 3. Numbers (1) and (8) indicate offset fan edges, (2) - (7) note heads and outlets of channels used for restoration. (B) Restoration of $125 \pm 8$ $\mathrm{m}$ of sinistral offset. Gap in the center is accommodated by minor oblique motion along the Toguz-Bulak fault. 

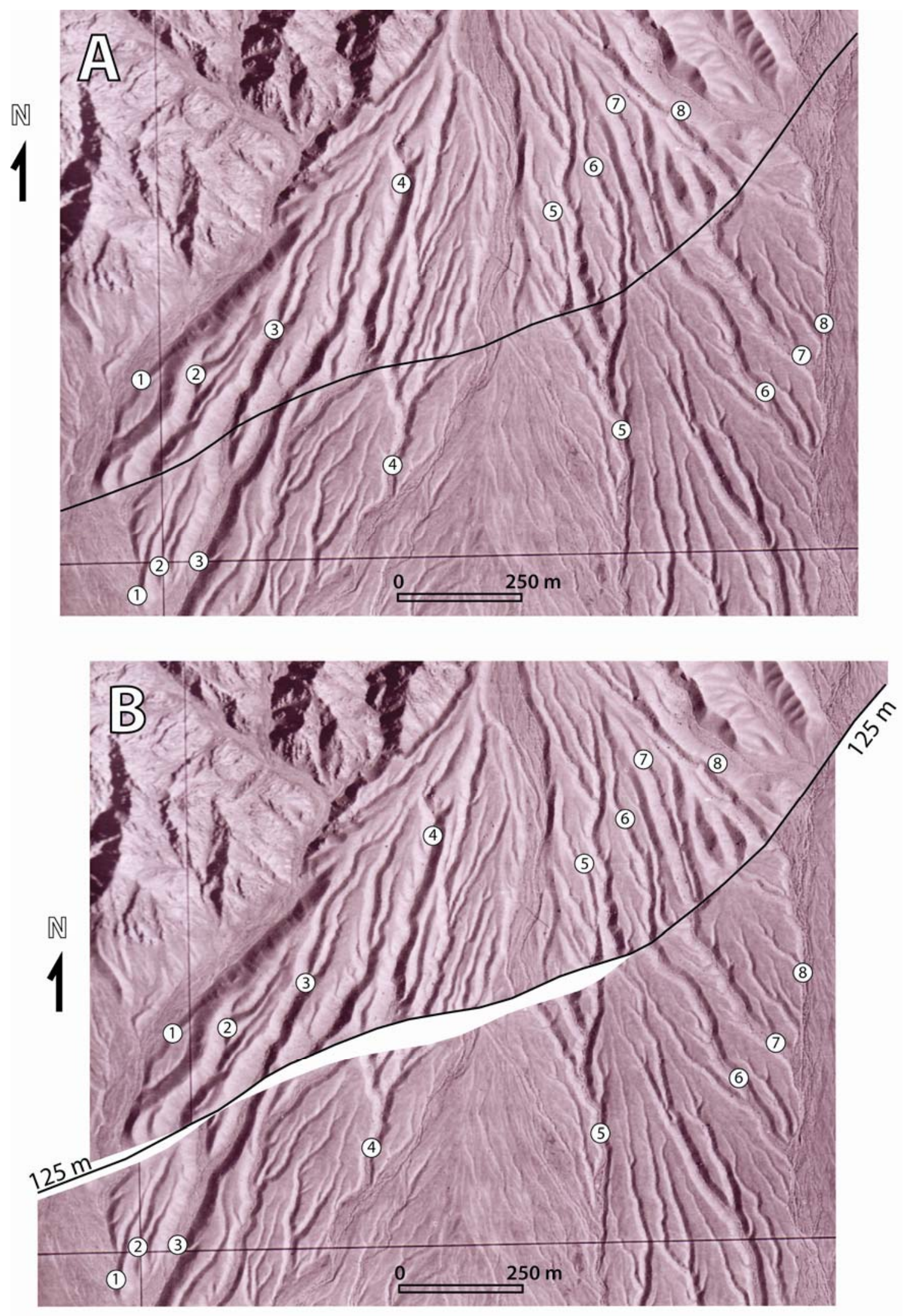
Figure 6. Sinistral offset along the Toguz-Bulak fault east of the Balikche fault. Location shown in Fig. 4. Offset was measured from: (1) channel offset, measured from abandoned paleochannel to the present-day thalweg; (2) offset of eastern channel edge; (3) offset of Q3 deposit edge. $95 \pm 8 \mathrm{~m}$ of offset is present in the channel and Q3 2 edge.

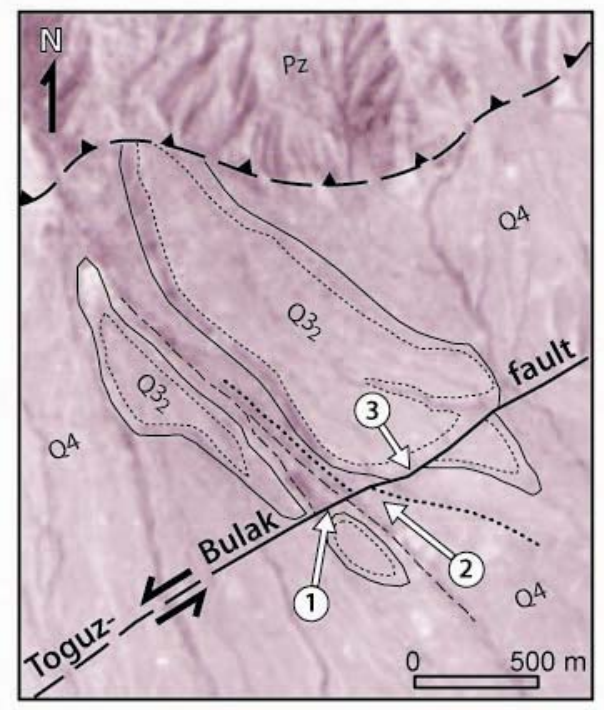

Most of the range-bounding structures of the western Kungey Range show abundant evidence of late Quaternary activity. Two sites along the Toguz-Bulak fault sinistrally offset Q32 alluvial fans. These sites are separated by the Balikche fault, a northwest-striking reverse fault that branches southward from the Toguz-Bulak fault into the Issyk-Kul basin. West of the Balikche fault, the Toguz-Bulak fault sinistrally displaces a Q3 $3_{2}$ alluvial fan and several inset channels by $125 \pm 8 \mathrm{~m}$ (Fig. 5). East of the Balikche fault, the fault displaces the margins of a channel inset into Q3 $3_{2}$ by $95 \pm 8 \mathrm{~m}$ (Fig. 6). The Balikche fault itself shows evidence of Holocene activity, with a northeast-facing scarp and displacement of a Q4 fan by $7 \pm 2 \mathrm{~m}$. Strike-slip on the Toguz-Bulak fault feeds into active, east-west striking thrust faults and folds along the Toru-Aygir River valley (Korjenkov, 2000; Bowman et al., 2004; Korjenkov et al., 2007). The Ak-Teke fault is the most active and largest spatially of these and displaces and warps preserved Q2 $1, \mathrm{Q}_{2}, \mathrm{Q}_{1}, \mathrm{Q}_{2}, \mathrm{Q}_{3}$ and Q4 surfaces (Fig. 7). Displacement along the Ak-Teke fault was measured at $48 \pm 4 \mathrm{~m}$ in Q2 2 and $32 \pm 3 \mathrm{~m}$ in Q3 ${ }_{2}$. A scarp in Q4 shows a vertical offset of 2 m (Korjenkov, 2000). East of Toru-Aygir slip on the Ak-Teke fault decreases to $21 \pm 2 \mathrm{~m}$ in Q3 2 (Fig. 7). 

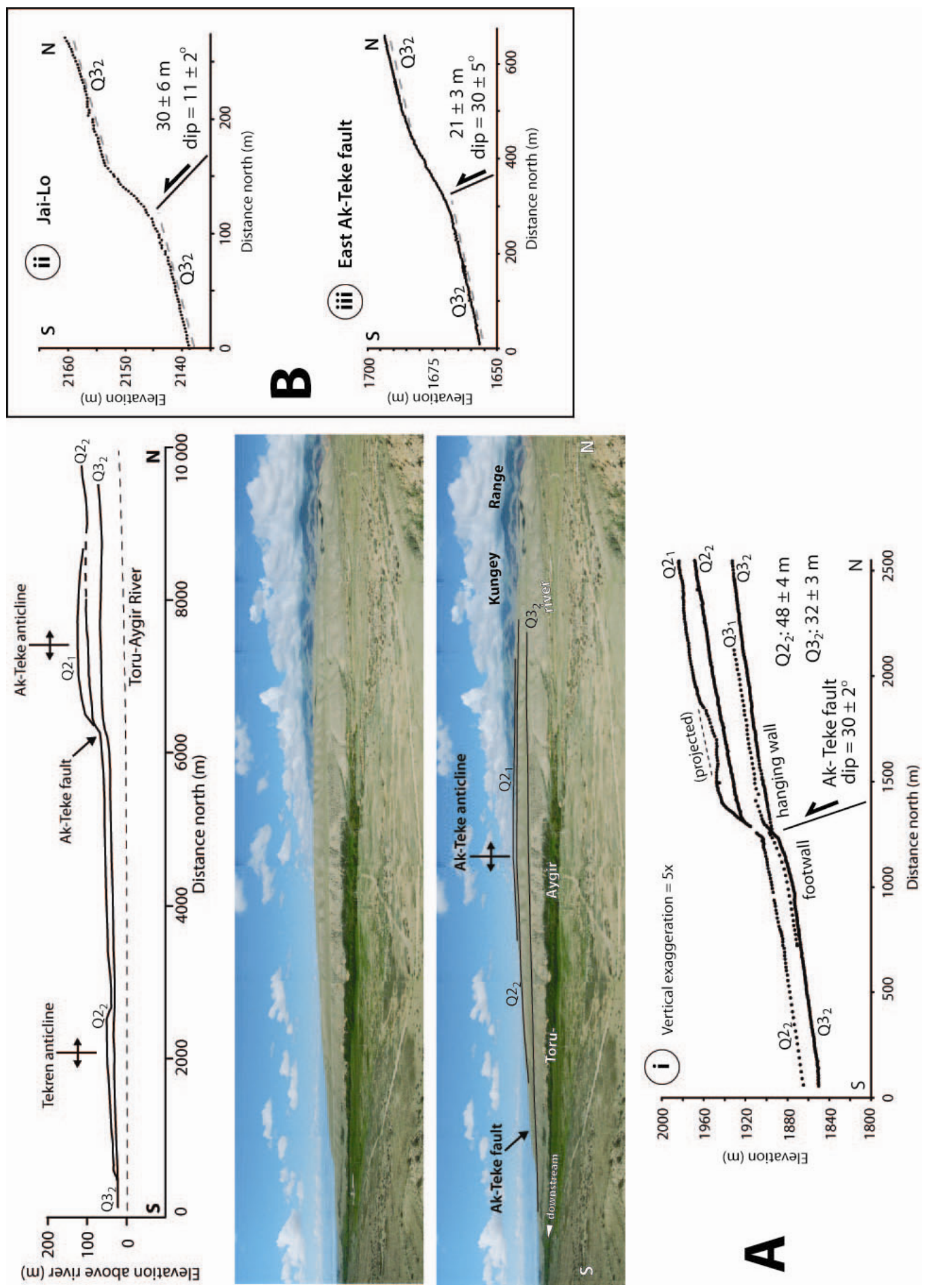
Figure 7. (A) Top: Surveyed profile of the Ak-Teke and Tekren anticlines. Profile rotated $5^{\circ}$ to remove river gradient. Vertical exaggeration $\sim 9 \mathrm{x}$. Center: Photo mosaic of the AkTeke anticline, looking west. Bottom: Detailed surveys across the Ak-Teke fault on the west side of the Toru-Aygir River. Surveys made in location (i) in Fig. 4. Vertical exaggeration = 5x. (B) Scarp profiles from locations (ii) and (iii) in Fig. 4. Vertical exaggeration $=5 x$.

South of the Ak-Teke fault, the Tekren anticline deforms Q2, $\mathrm{Q}_{2}$ and Q4 surfaces with only a minor amount of shortening, $10 \pm 4 \mathrm{~m}$, measured from the deflection of Q2 . Thrusting in the core of the Jai-Lo syncline also deforms Q3 ${ }_{2}, \mathrm{Q}_{3}$ and Q4 surfaces with an offset of $30 \pm$ $6 \mathrm{~m}$ in $\mathrm{Q}_{2}$ (Fig. 7).

\subsection{Central Kungey Range}

Basement uplift across the central Kungey Range is accomplished by a series of north- and south-vergent reverse faults (Fig. 8 and Plate 2). North of the town of CholponAta, these faults displace the unconformity surface. Where preserved at the range front, this surface dips uniformly south $\sim 25^{\circ}$. South of the range front, the south-vergent CholponBosteri fault bounds an open, east-west trending syncline developed in Neogene strata. Paleozoic rocks are locally exposed on the south limb of the syncline, thus the basement is presumably folded similar to the Neogene strata. Conformable Neogene strata on the north limb of the syncline are locally overturned on the south limb in the Svalka anticline. East of Cholpon-Ata the unconformity surface and overlying Neogene strata uniformly dip 25-30 south near the range front. South-vergent faulting with minor displacements disrupts the overlying Neogene and Quaternary deposits, but likely roots into basement at shallow depths. Evidence of faulting disappears east of the Chon-Aksu River and exposure of the Neogene strata defines a south-dipping homocline overlying the unconformity surface. 


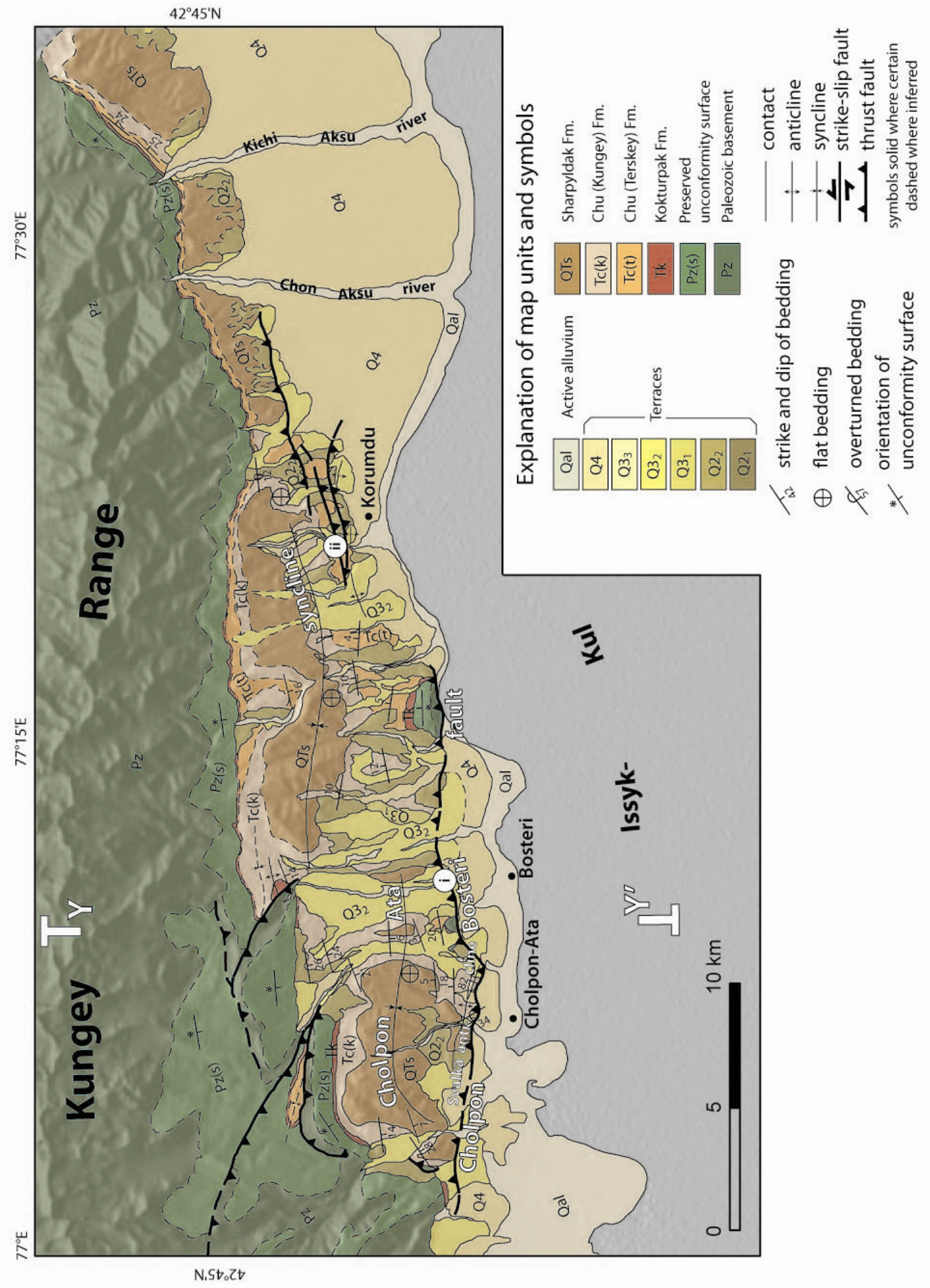

Figure 8. Detailed Neogene and Quaternary geology of the central Kungey Range, location noted in Fig. 1. Line $\mathrm{Y}-\mathrm{Y}^{\prime}$ ' indicates cross-section line in Fig. 16. Locations (i) and (ii) show where detail fault scarp surveys were made, shown in Fig. 9. 
Figure 9. (A) Photo of $\mathrm{Q}_{2}$ offset along the Cholpon-Bosteri fault at location (i) from Fig. 8. Photo is looking east. (B) Surveyed profiles across fault scarps at locations (i) and (ii) from Fig. 8. Vertical exaggeration $=5 \mathrm{x}$.
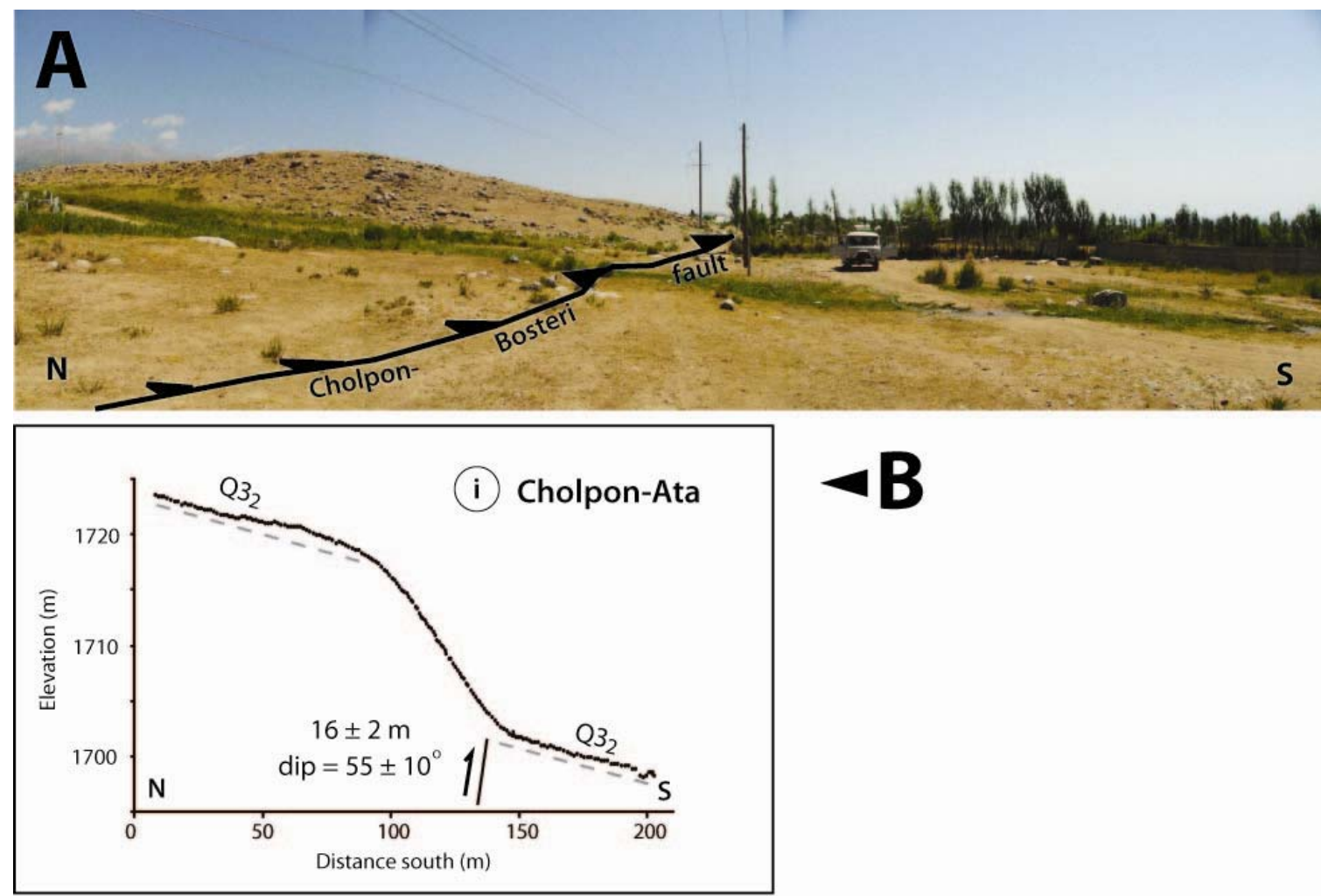

$-B$

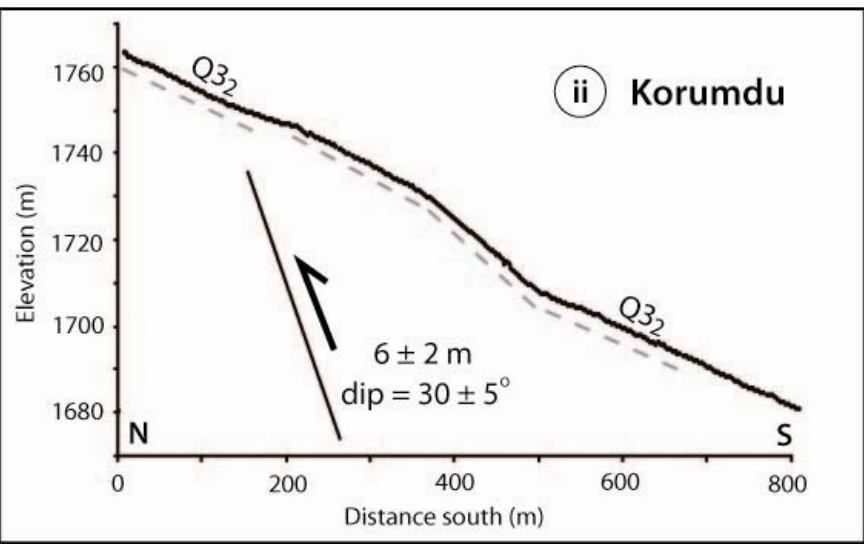

Active deformation in the central Kungey Range is expressed by slip along the Cholpon-Bosteri fault system. Unlike the western Kungey Range, all late Quaternary deformation along the central Kungey Range front occurs via thrust or reverse faulting. Where bounding the southern limb of the Neogene syncline, the Cholpon-Bosteri fault dips 
$\sim 55^{\circ}$ north as calculated by local topographic expression of the fault trace. In the town of Cholpon-Ata, this fault displaces Q2 $2, \mathrm{Q}_{2}$ and Q4 surfaces. Slip in Q3 2 measured at $16 \pm 2$ m (Fig. 9). East of Cholpon-Ata, north-facing scarps in deformed terraces indicate a change of fault geometry and decrease of deformation rate. Deformation appears to transfer from the Cholpon-Bosteri fault to north-vergent back-thrusts near the town of Korumdu. Older, inactive back-thrusts deform $\mathrm{Q}_{2}$ surfaces, younger back-thrusts are expressed via small scarps and hanging-wall anticlines in Q32. Slip measured across the scarp and back limb of an anticline on one of these back-thrusts is $6 \pm 2 \mathrm{~m}$ in Q3 2 (Fig. 9). Further east, fault scarps in $\mathrm{Q}_{2}$ and $\mathrm{Q} 3{ }_{2}$ surfaces indicate a return to south-vergent, shallow structures. These scarps diminish eastward and disappear entirely near the Chon-Aksu River.

\subsection{Chon-Kemin and Chon-Aksu Valleys}

The east-northeast striking Kemin-Chilik fault zone runs longitudinally through the Chon-Kemin river valley, separating the Kungey Range from the Zailiskey Range. The Kemin-Chilik fault is a re-activated Paleozoic-Mesozoic sinistral fault zone with offset basement terranes (Delvaux et al, 1999, 2001). Late Quaternary sinistral motion is evidenced by sinistral offset in undifferentiated fluvial terraces along strands of the fault, while historical ruptures along the fault zone show both sinistral and reverse motion (Tapponnier and Molnar, 1979; Molnar and Ghose, 2000; Delvaux et al., 2001; Crosby et al., 2005, 2007).

The Chon-Aksu valley cuts east-west through the Kungey Range northeast of Cholpon-Ata. Running through this valley is the $45^{\circ}-60^{\circ}$ northeast-dipping Chon-Aksu fault (Delvaux et al., 2003; Crosby et al., 2005). Trenching along the Chon-Aksu fault shows $\sim 4$ major events within the past $12 \mathrm{kyr}$, the most recent being the 1911 Kemin earthquake (Delvaux et al., 1999; Delvaux et al., 2001; Arrowsmith et al., 2004; Crosby et al., 2005). 
The 1911 event also ruptured segments of the Kemin-Chilik fault with sinistral-oblique motion expressed at the surface (Delvaux et al., 1999). Ruptures along the Chon-Aksu fault associated with this event display both reverse and normal motion with vertical displacements of 2-8 m (Arrowsmith et al., 2004).

\subsection{Northern Zailiskey Range}

The basement uplifts of the Zailiskey Range are bounded on the north by a system of north-verging thrust and reverse faults (Fig. 10). Where preserved, the Cenozoic unconformity surface is north-dipping and generally overlain by a conformable Neogene sedimentary section. Along the eastern range front near Chilik, basement is upthrust above a series of south-vergent reverse faults that step progressively northward (Tibaldi et al., 1997).

Near Almaty, the Neogene section is buried by a loess deposit of unknown thickness. Based upon topographic expression and limited exposures of Neogene strata, the range front east of Almaty appears to have been warped into a series of east-west-trending anticlines (Fig. 10). Further east, the loess cover diminishes and outcrops of Neogene sedimentary units are common. South of Chilik, these sediments have been uplifted and warped into east-westtrending, east-plunging anticlines. East of Chilik the Neogene section is exposed in a $6^{\circ}$ $17^{\circ}$ north-dipping conformable section on top of the Cenozoic unconformity surface.

Quaternary deformation along the Zailiskey Range front is expressed by fault scarps and folding of a regional terrace sequence that appears correlative to the terrace sequence in the Issyk-Kul basin. Unnamed faults that displace the terraces have reverse and minor oblique-slip geometries. Analogous Q4 surfaces along the range front that cross reverse faults have scarps $\sim 3-5 \mathrm{~m}$ in height, Q3 and Q2 surfaces have progressively more deformation. South of Chilik the range front shows evidence for Quaternary activity along 
two north-vergent thrust faults. Displacement of Q2 surfaces was measured at $40 \pm 20 \mathrm{~m}$ along the southern fault proximal to the range, and $72 \pm 30 \mathrm{~m}$ on the northern fault (Fig. 11).

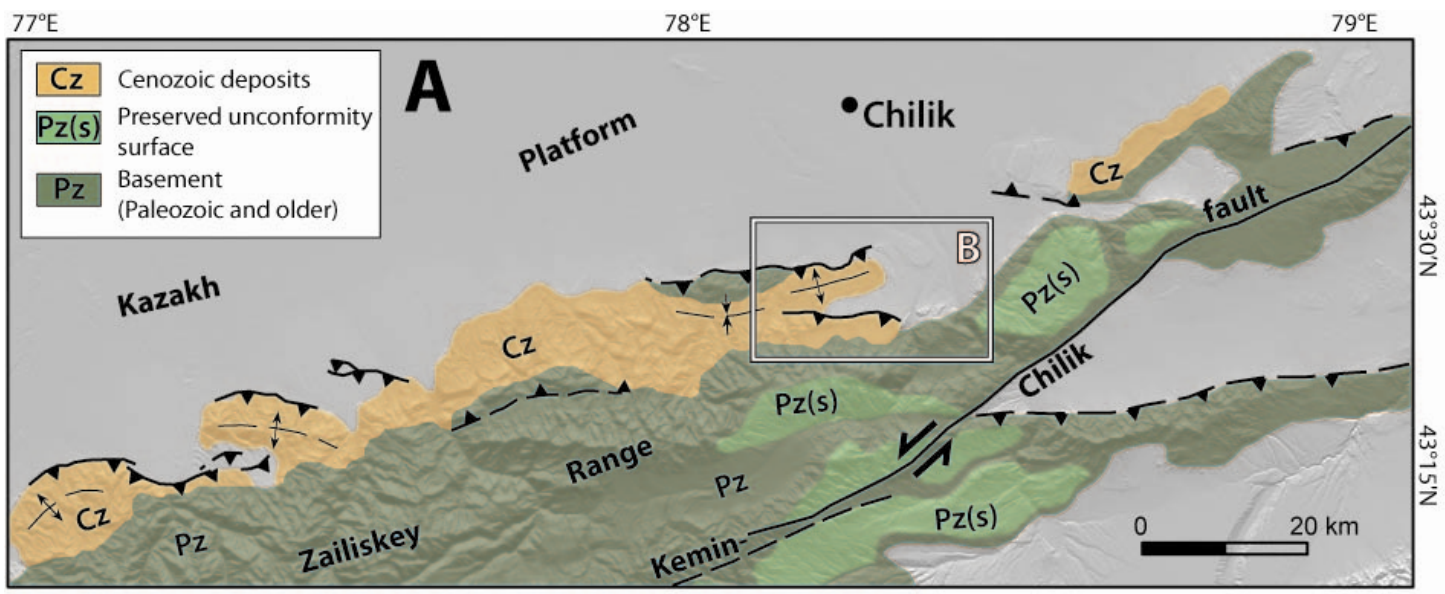

Explanation of map units and symbols

\begin{tabular}{|c|c|c|c|c|c|c|}
\hline Qal & Active alluvium & QTs & Sharpyldak Fm. equivalent & & contact & Ind dip of bedding \\
\hline Q4 & \multirow{3}{*}{ Terraces } & Tc & Chu Fm. equivalent & & anticline & \\
\hline Q3 & & $P z(s)$ & Preserved & 2 & $\begin{array}{l}\text { synciine } \\
\text { strike-slin fault }\end{array}$ & unc \\
\hline Q2 & & $\mathrm{Pz}$ & Paleozoic basement & & thrust or reverse fault & $\begin{array}{l}\text { ymbols solid where certain } \\
\text { dashed where inferred }\end{array}$ \\
\hline
\end{tabular}

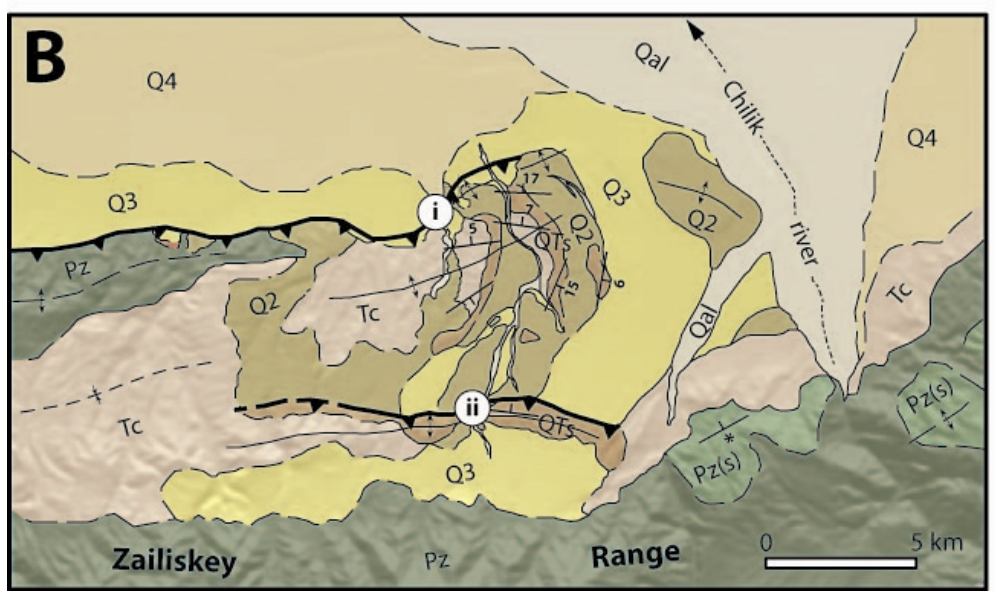

Figure 10. (A) Generalized geology of the northern Zailiskey Range, showing major structures, preserved Cenozoic deposits and locations where the Cenozoic unconformity surface is exposed. Location noted in Fig. 1. (B) Detailed Neogene and Quaternary geology near Chilik. Locations (i) and (ii) show where fault surveys were made, shown in Fig. 11. 

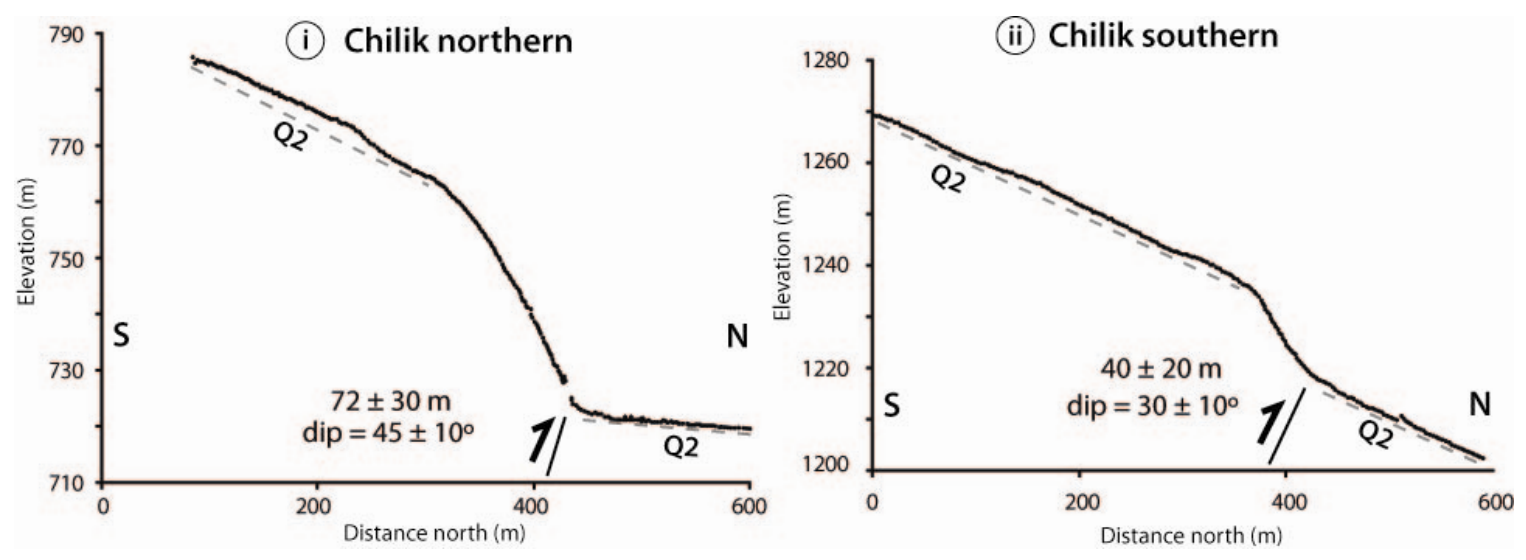

Figure 11. Detailed fault scarp surveys from the northern Zailiskey Range near Chilik. Locations of (i) and (ii) are noted in Fig. 10, vertical exaggeration $=5 \mathrm{x}$. 


\section{Geochronology}

We selected a well-preserved chronosequence of alluvial terraces along the ToruAygir River for cosmogenic ${ }^{10} \mathrm{Be}$ exposure age dating. Samples for analysis were collected from depth profiles to simultaneously determine terrace age and account for ${ }^{10} \mathrm{Be}$ inherited during erosion, transport, and deposition of sediment (Anderson et al. 1996; Repka et al., 1997; Perg et al., 2001).

Cosmogenic ${ }^{10} \mathrm{Be}\left(t_{1 / 2}=1.36\right.$ m.y. $)$ is produced in quartz from the spallation of $\mathrm{O}$ and Si when exposed to high-energy cosmic rays (Cerling and Craig, 1994). For a stable, noneroding surface, in-situ ${ }^{10} \mathrm{Be}$ accumulation can be described by the exponential equation (after Lal, 1988; Perg et al., 2001):

$$
\mathrm{C}_{d}=\mathrm{C}_{i}+\mathrm{P}_{\mathrm{o}} \mathrm{te}^{\left(-\mathrm{z} / \mathrm{z}^{*}\right)}
$$

where $\mathrm{C}_{d}$ is the concentration of ${ }^{10} \mathrm{Be}$ at depth (atoms/g), inherited ${ }^{10} \mathrm{Be} \mathrm{C}_{i}$ (atoms/g), production rate $\mathrm{P}_{\mathrm{o}}($ atoms $/ \mathrm{g} / \mathrm{yr})$, age of the surface $\mathrm{t}(\mathrm{yr})$, depth of sample $\mathrm{z}(\mathrm{cm})$, and $\mathrm{z}^{*}$ the characteristic attenuation length scale for unconsolidated alluvium calculated from a meanfree path of $165 \mathrm{~g} / \mathrm{cm}^{2}$ (Brown et al, 1992). For unconsolidated alluvium we use a bulk sediment density of $2.0 \mathrm{~g} / \mathrm{cm}^{3}$, yielding $\mathrm{z}^{*}$ value of $82.5 \mathrm{~cm}$. Decay of ${ }^{10} \mathrm{Be}$ may be ignored on time scales much shorter than its half-life (Lal, 1991)

To solve for inheritance and terrace age, we convert equation (1) into a linear expression by the substitution

$$
\mathrm{z}^{\prime}=\mathrm{e}^{\left(-\mathrm{z} / \mathrm{z}^{*}\right)}
$$

Thus equation (1) can be represented as 


$$
\mathrm{C}_{d}=\mathrm{C}_{i}+\mathrm{P}_{\mathrm{o}} \mathrm{tz}^{\prime}
$$

Using this linear relationship, measured $\mathrm{C}_{d}$ and calculated $\mathrm{P}_{\mathrm{o}}$ and $\mathrm{z}^{\prime}$, equation (3) is solved for values of inheritance, $\mathrm{C}_{i}$ and terrace age, $\mathrm{t}$.

Samples were taken from flat terrace surfaces well away from convex, actively eroding edges. Pits were dug into $\mathrm{Q} 2{ }_{1}, \mathrm{Q} 22_{2}$ and $\mathrm{Q} 33_{2}$ terraces to a depth of $170 \mathrm{~cm}$. Quartzrich clasts ranging in size from 1 to $10 \mathrm{~cm}$ were taken by hand from depths of $170,100,50$, 25 and $10 \mathrm{~cm}$ and from the surface of the terrace proximal to each pit. Samples were crushed and sieved to isolate a $250-500 \mu \mathrm{m}$ fraction. Standard quartz separation techniques were followed, and targets of ${ }^{10} \mathrm{Be}$ were prepared for analysis at the University of Minnesota Cosmogenic Lab. Analysis was performed at the Lawrence Livermore National Laboratory accelerator mass spectrometer.

Production rates $\left(\mathrm{P}_{\mathrm{o}}\right)$ for ${ }^{10} \mathrm{Be}$ in the western Kungey Range were calculated using methods described by Pigati and Lifton (2004). Time-averaged production rates vary with altitude, and to a lesser extent, with terrace age. We find $\mathrm{P}_{\mathrm{o}}$ values of 26.0, 24.8 and 24.3 atoms ${ }^{10} \mathrm{Be} / \mathrm{g} / \mathrm{yr}$ for $\mathrm{Q} 2_{1}, \mathrm{Q}_{2}$ and $\mathrm{Q} 3_{2}$, respectively and use equation (3) to solve for the age of each surface. The depth profiles are exceptionally well behaved (Fig. 12). Our model ages, cited with a $95 \%$ confidence interval, are $139.9 \pm 6.5 \mathrm{ka}$ for $\mathrm{Q} 2{ }_{1}, 126.4 \pm 10.8 \mathrm{ka}$ for Q2 2 and $85.6 \pm 7.6 \mathrm{ka}$ for $\mathrm{Q}_{2}$ (Fig. 12 and Table 2). 


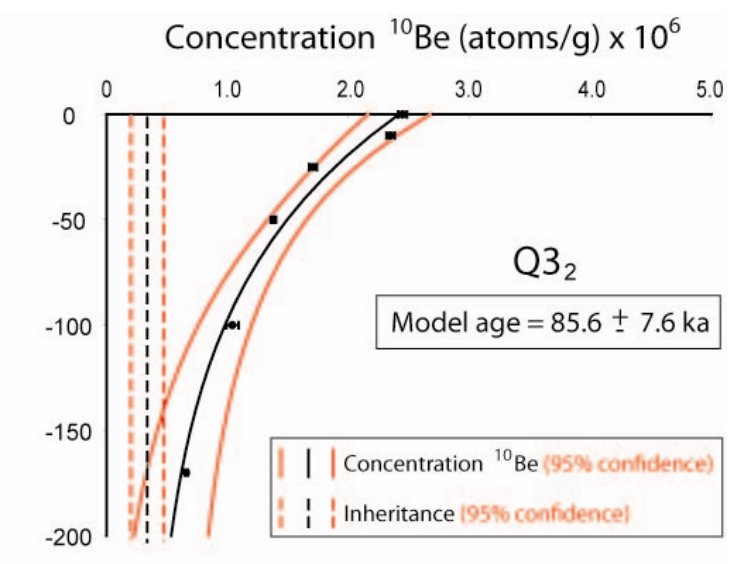

Inheritance $=13.8 \pm 5.2 \mathrm{ka}$
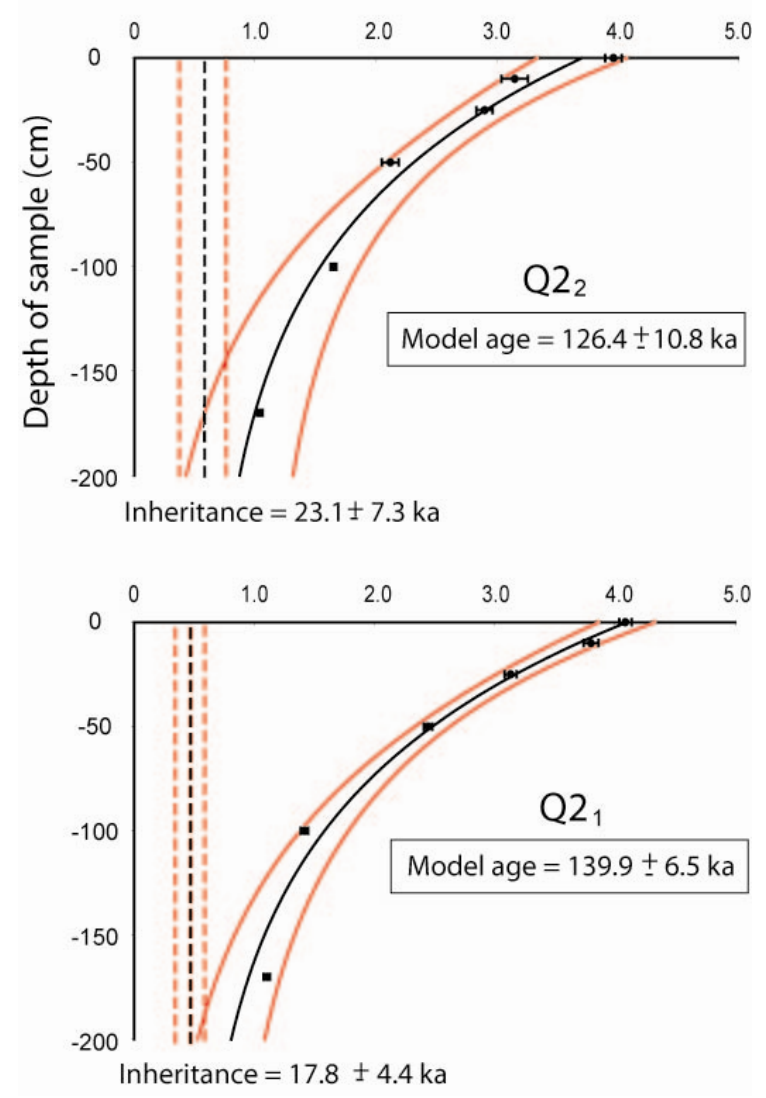

Figure 12. Concentrations of ${ }^{10} \mathrm{Be}$ at depth for $\mathrm{Q} 3{ }_{2}, \mathrm{Q} 2{ }_{2}$, and $\mathrm{Q} 21$ terrace surfaces along the Toru-Aygir River valley. Depth profiles and inheritance (equivalent age) values are presented with 95\% confidence interval. Data used in plots is presented in Table 2. 


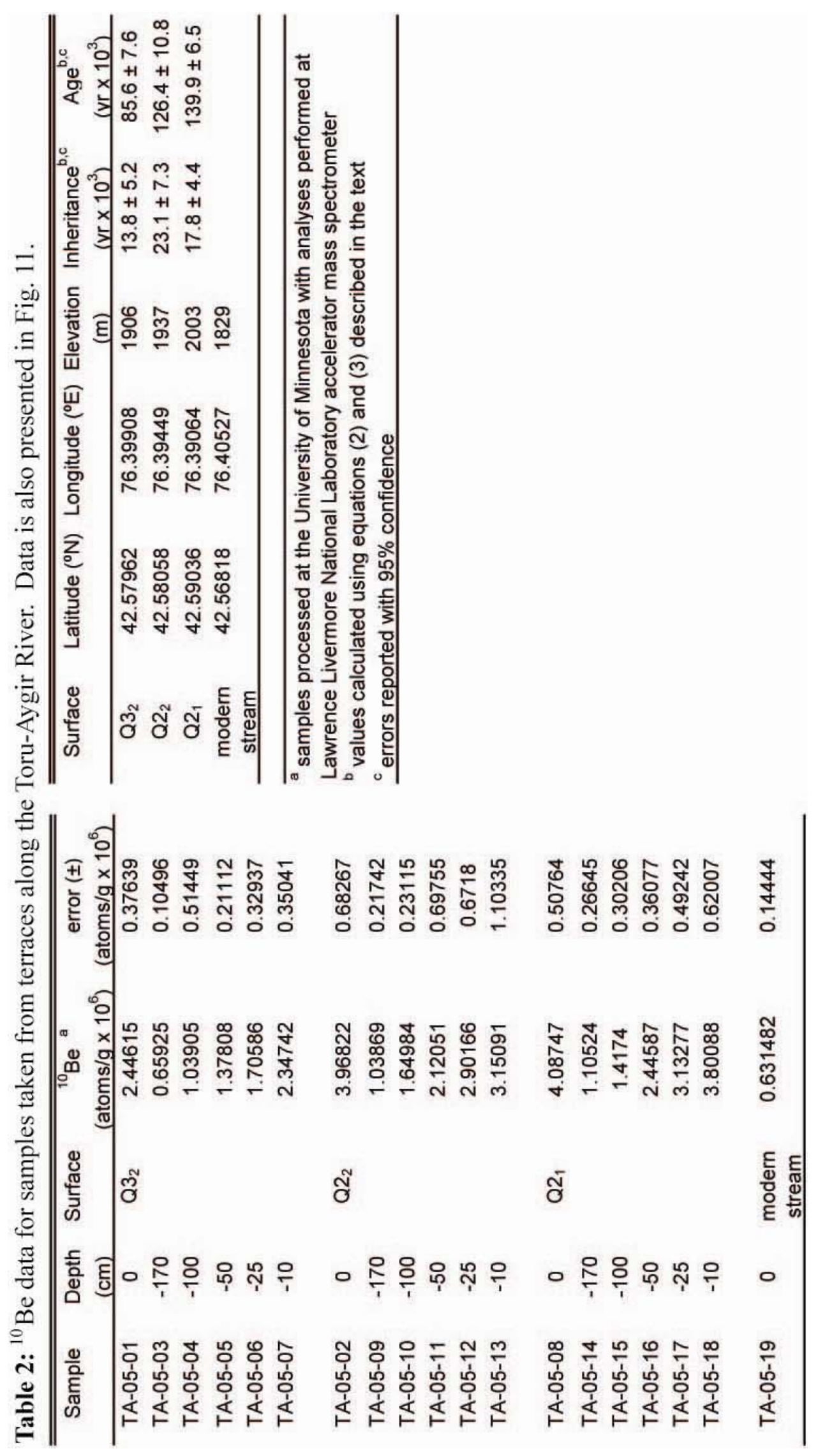




\section{Late Quaternary deformation rates}

Late Quaternary deformation expressed as folded and faulted fluvial terraces was studied to determine styles and rates of deformation (Table 3 and Fig. 13). Fault scarps in preserved terrace surfaces were field mapped on aerial photography and surveyed with a differential GPS to determine offset and fault geometry. Lateral offsets of terrace edges and ephemeral stream channels were measured to determine strike-slip displacement, where present. Amount of slip along thrust faults was calculated from scarp profiles using the methodology of Thompson et al. (2002, Appendix A) taking into account uncertainty in the dip of hanging wall and footwall terrace surfaces and backlimb shortening, where applicable. Fault dip was measured from topographic exposure of scarp faces, estimated from similarly deforming areas with known fault dip, or based on cross-section interpretations. Slip rates

were calculated using ${ }^{10} \mathrm{Be}$ ages for offset surfaces. Monte Carlo simulations with 10,000 calculations give slip rates with a 95\% confidence interval.

Fault slip rates are highest in the western Kungey Range where sinistral motion along the Toguz-Bulak fault feeds into a series of east-west trending faults and folds along the Toru-Aygir river valley (Fig. 13). An overall gradient in slip rates, decreasing from west to east, is observed along the range front. Along the Toguz-Bulak fault, sinistral slip rates decrease from $1.4 \pm 0.2 \mathrm{~mm} / \mathrm{yr}$ to $1.1 \pm 0.2 \mathrm{~mm} / \mathrm{yr}$ across the intersection with the Balikche fault. Total north-south shortening rate along parallel east-west trending faults and folds in the Toru-Aygir river valley is approximately $1 \mathrm{~mm} / \mathrm{yr}$. Slip rates along the Ak-Teke fault diminish slightly along strike from west to east from $\sim 0.4 \mathrm{~mm} / \mathrm{yr}$ to $<0.3 \mathrm{~mm} / \mathrm{yr}$. Late 


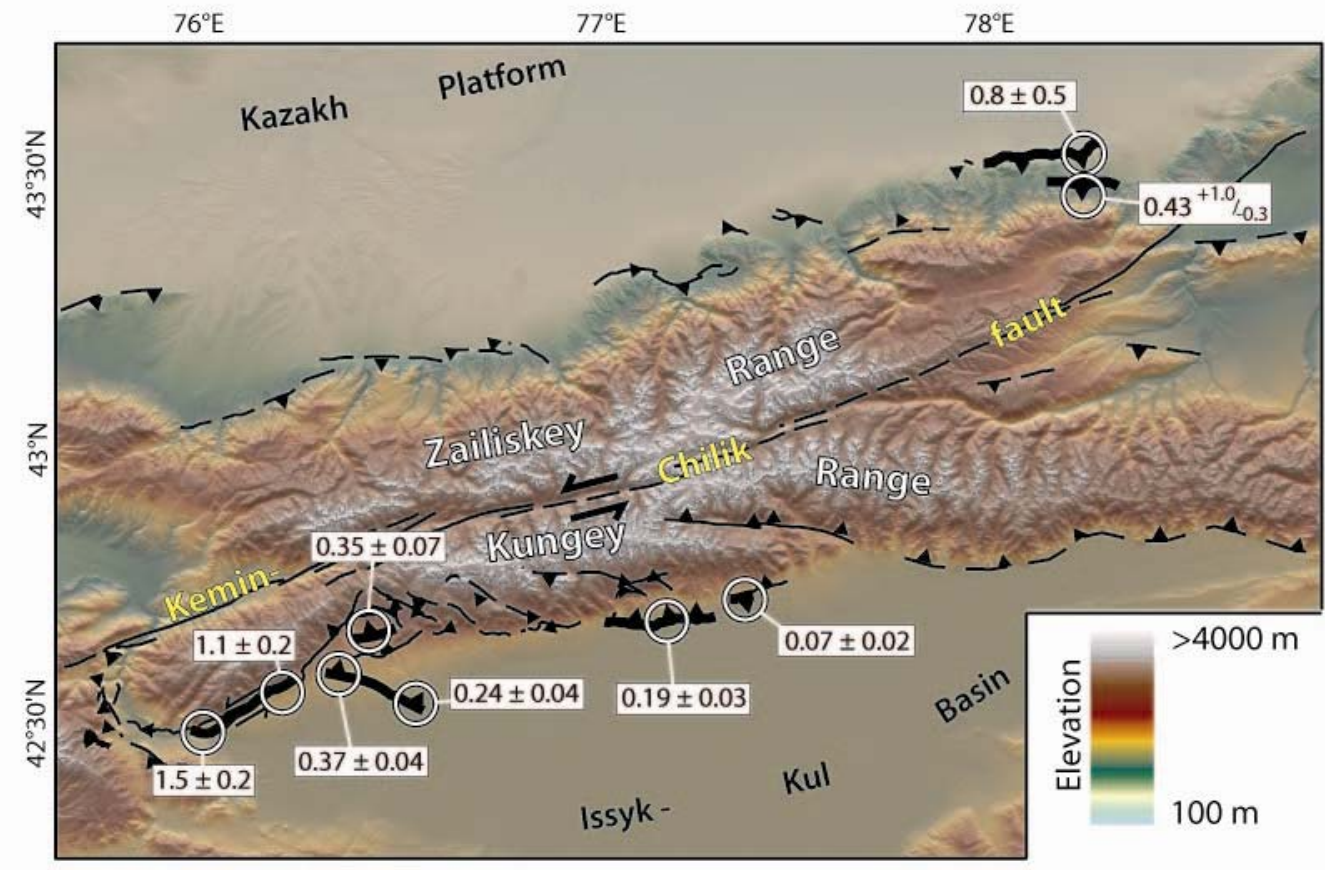

Figure 13. Summary of late Quaternary fault slip rates for the northern Tian Shan. Faults where detailed studies were made are noted in bold, slip rates are presented in $\mathrm{mm} / \mathrm{yr}$ with a 95\% confidence interval. Slip rate data is presented in Table 3.

Table 3: Slip rates and fault data from the Kungey and Zailiskey Ranges.

\begin{tabular}{|c|c|c|c|c|c|}
\hline Fault & Location & Fault dip & Surface ${ }^{1}$ & Offset (m) & Slip rate $(\mathrm{mm} / \mathrm{yr})^{2}$ \\
\hline \multirow[t]{2}{*}{ Toguz-Bulak $^{\text {a }}$} & West of Balikche & $\mathrm{n} / \mathrm{a}$ & $\mathrm{Q3}_{2}$ & $125 \pm 8^{a}$ & $1.5 \pm 0.2^{a}$ \\
\hline & North of Balikche & $\mathrm{n} / \mathrm{a}$ & $\mathrm{Q}_{2}$ & $95 \pm 8^{a}$ & $1.1 \pm 0.2^{a}$ \\
\hline \multirow[t]{3}{*}{ Ak-Teke } & Toru-Aygir river valley & $30 \pm 2^{\circ}$ & $\mathrm{Q}_{2}$ & $32 \pm 3$ & $0.37 \pm 0.04$ \\
\hline & & & $\mathrm{Q}_{2}$ & $48 \pm 4$ & $0.38 \pm 0.04$ \\
\hline & East of Toru-Aygir & $30 \pm 5^{\circ}$ & $\mathrm{Q}_{2}$ & $21 \pm 3$ & $0.24 \pm 0.04$ \\
\hline Un-named & Jai-Lo syncline & $11 \pm 2^{\circ}$ & $\mathrm{Q}_{2}$ & $30 \pm 6$ & $0.35 \pm 0.07$ \\
\hline \multirow[t]{2}{*}{ Cholpon-Bosteri } & North of Cholpon-Ata & $55 \pm 10^{\circ}$ & $\mathrm{Q}_{2}$ & $16 \pm 2$ & $0.19 \pm 0.03$ \\
\hline & North of Korumdu & $30 \pm 5^{\circ}$ & $\mathrm{Q}_{2}$ & $6 \pm 2$ & $0.07 \pm 0.02$ \\
\hline Un-named northern & Chilik & $45 \pm 10^{\circ}$ & Q2* & $72 \pm 30$ & $0.8 \pm 0.5$ \\
\hline Un-named southern & Chilik & $30 \pm 10^{\circ}$ & Q2* & $40 \pm 20$ & $0.43^{+1.0} \%-0.3$ \\
\hline
\end{tabular}


Quaternary deformation rates continue to decrease to the east, where dip-slip reverse motion along the Cholpon-Bosteri fault diminishes from $\sim 0.25 \mathrm{~mm} / \mathrm{yr}$ to $<0.1 \mathrm{~mm} / \mathrm{yr}$ (Fig. 13).

Slip rates were estimated along two thrust faults in the eastern Zailiskey Range front near Chilik (Fig. 13). Offset was measured from deformed Q2 surfaces. We assume an age of $100 \pm 30$ ka for this terrace, which encompasses ages for Q2 elsewhere in the Tian Shan from this study, Thompson et al. (2002), and Bowman et al. (2004). For the southern fault we find a rate of $0.43+1 /-0.3 \mathrm{~mm} / \mathrm{yr}$. The slip rate of the northern fault is about twice this amount, $0.8 \pm 0.5 \mathrm{~mm} / \mathrm{yr}$. 


\section{Discussion}

Within the context of the northward propagation of the Tian Shan, the growth history of the Kungey and Zailiskey Ranges is discussed in relation to the central, inherited KeminChilik fault. By interpreting the structural evolution of these ranges in map-view and in cross-section, it is inferred that these have grown as a mega-flower structure, with the Kemin-Chilik fault at its core. This pattern of active shortening is shown to be incompatible with a transform fault model for the Kemin-Chilik fault. Rather, the pattern of faulting is shown to be consistent with the mechanical model of oblique fault reactivation of Bowman et al. (2003). Because inherited strike-slip faults are common within the basement-cored uplifts of the Tian Shan, the generation of high-angle reverse faults via reactivation of nearby, obliquely oriented, inherited faults may be a general feature of the orogen (Burtman, 1975; Sengor et al., 1993; Delvaux et al., 1999; Burtman et al., 1996; Mikolaichuk et al., 2000; Abdrakhmatov et al., 2001; Buslov et al., 2003).

\subsection{Stratigraphic evidence for uplift history}

Preceding uplift, a foreland flexural basin occupied the region of the Kungey and Zailiskey Ranges. Facies of the Shamsi formation in the Chu Basin (Bullen et al., 2001), western Kungey Range, and Terskey Range (Thomas et al., 1993; Bazhenov et al., 1994) record subsidence of the foreland basin and burial of the northern Tian Shan prior to $7 \mathrm{Ma}$ (Bullen et al., 2001, 2003; Sobel et al., 2006). Absence of the Shamsi formation in presentday eastern Kungey Range stratigraphy defines the lateral extent of this flexural basin. 
Expansion of this flexural basin is recorded by the Chu (Terskey) Fm., present in outcrops along both the western and eastern Kungey Range front.

Inception of uplift of the Kungey Range and initial closure of the Issyk-Kul basin occurred during deposition of the Chu Fm., ostensibly between 7 and 4 Ma. This transition is indicated by a reversal of paleocurrents and a change in clast lithology. Paleocurrent indicators in the Chu (Terskey) Fm. record a south-to-north transport of distally derived sediments. This transitions upsection to locally-derived grus of the Chu (Kungey) Fm. Production of grus via erosion of exposed bedrock typically occurs at rates of $<0.01 \mathrm{~mm} / \mathrm{yr}$ (Small et al., 1997), thus it is interpreted that the thick section (400-600 m) of grus and thin gravel conglomerates records initial slow uplift and erosion of the Kungey Range.

Upward-coarsening of the Chu (Kungey) Fm. into the conglomerates of the Sharpyldak Fm. signifies increasing relief of the Kungey Range source area. Within the Sharpyldak Fm., the absence of observed growth strata (e.g. fanning dips) indicates deposition of these conglomerates prior to the inception of folding along the present southern margin of the growing Kungey Range. Stratigraphy present along the Zailiskey Range front displays similar attributes as the Kungey Range stratigraphy. The Zailiskey Chu Fm. equivalent also exhibits a coarsening-upward sequence into equivalent Sharpyldak conglomerates. Likewise, these locally derived conglomerates suggest a south-to-north growth of the Zailiskey Range from the Kemin-Chilik fault into the Kazakh Platform. The timing of influx of coarse detritus into these flanking basins is poorly understood, as the depositional age of the Sharpyldak Fm. is unlikely to be the same as in the better-studied Chu basin section of Bullen et al. (2001). The best estimate for the age of onset of significant 
uplift of the Kungey and Zailiskey Ranges is sometime after the Shamsi-Chu transition, circa 7 Ma (Abdrakhmatov et al., 2001; Bullen et al., 2001).

\subsection{Structural evolution}

Subsurface geometries of faults responsible for the uplift of the Kungey and Zailiskey Ranges are inferred from structural measurements of Neogene stratigraphy and exposures of the deformed unconformity surface. The Kungey Range front and portions of the Zailiskey Range front are dominated by uniformly south- and north-dipping spatially extensive panels of the exhumed unconformity surface. While there are numerous ways to produce such a dip panel (e.g. Suppe, 1983; Erslev, 1986; Johnston and Yin, 2001), the subsurface fault geometries of the Kungey and Zailiskey Ranges must account for a steeply dipping, active fault at the core of the range (Tapponnier and Molnar, 1979; Tibaldi et al., 1997; Molnar and Ghose, 2000; Delvaux et al., 1999, 2001; Crosby et al., 2005, 2007). Rough seismicity of the northern Tian Shan shows events approximating a steeply-dipping feature extending to $\sim 20$ km depth in the region of the Kemin-Chilik Fault (Zubovich et al., 2001).

Reverse faults responsible for growth of the Kungey and Zailiskey Ranges have roughly linear map traces, especially where exposed high within the rages, consistent with relatively steep fault dips near the surface. Only the Ak-Teke fault, which appears to detach the Neogene section from Paleozoic basement, shows clear evidence of a gentle $\left(\sim 30^{\circ}\right)$ dip where it breaks the surface.

Based on these observations of the deformed unconformity surface and steep fault dips near the surface, the Kungey and Zailiskey Ranges are described using a positive flower structure fault geometry (Woodcock and Fischer, 1986) (Fig. 14) with curviplanar reverse faults that steepen at depth (e.g. Erslev, 1986) to root into the Kemin-Chilik fault. To 
investigate the overall structure of the Kungey Range, balanced cross-sections through the Toru-Aygir River valley (Fig. 15) and Cholpon-Ata syncline (Fig. 17) were constructed south of the Kemin-Chilik fault. Though these structural cross-sections are not unique, through presentation of these sections and their key structural observations insights are gained into overall range structure and its relation to the inherited strike-slip fault at the range core.

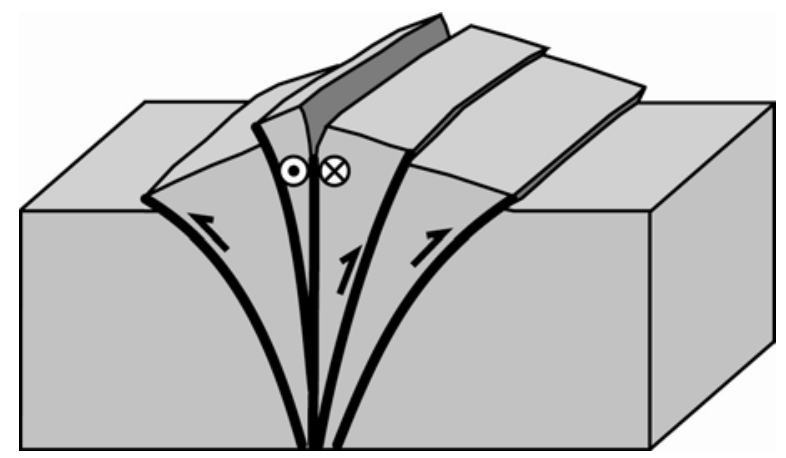

Figure 14. Schematic block diagram of a positive flower structure with reverse faults steepening at depth (After Erslev, 1986; Woodcock and Fischer, 1986) rooting into a central strike-slip fault. This geometry allows for simultaneous motion on all members of the fault network.

\subsubsection{Western Kungey Range}

A cross-section through the western Kungey Range was constructed along the ToruAygir river valley and north through the range (Fig. 15). Steeply-dipping reverse faults within the range proximal to the Kemin-Chilik fault are responsible for basement uplift but account for only minor amounts $(<1 \mathrm{~km})$ of shortening. To the south, the unconformity surface is preserved on both limbs of the Jai-lo syncline, where shortening is being accommodated via active faulting involving both Neogene sedimentary units and Paleozoic bedrock. 

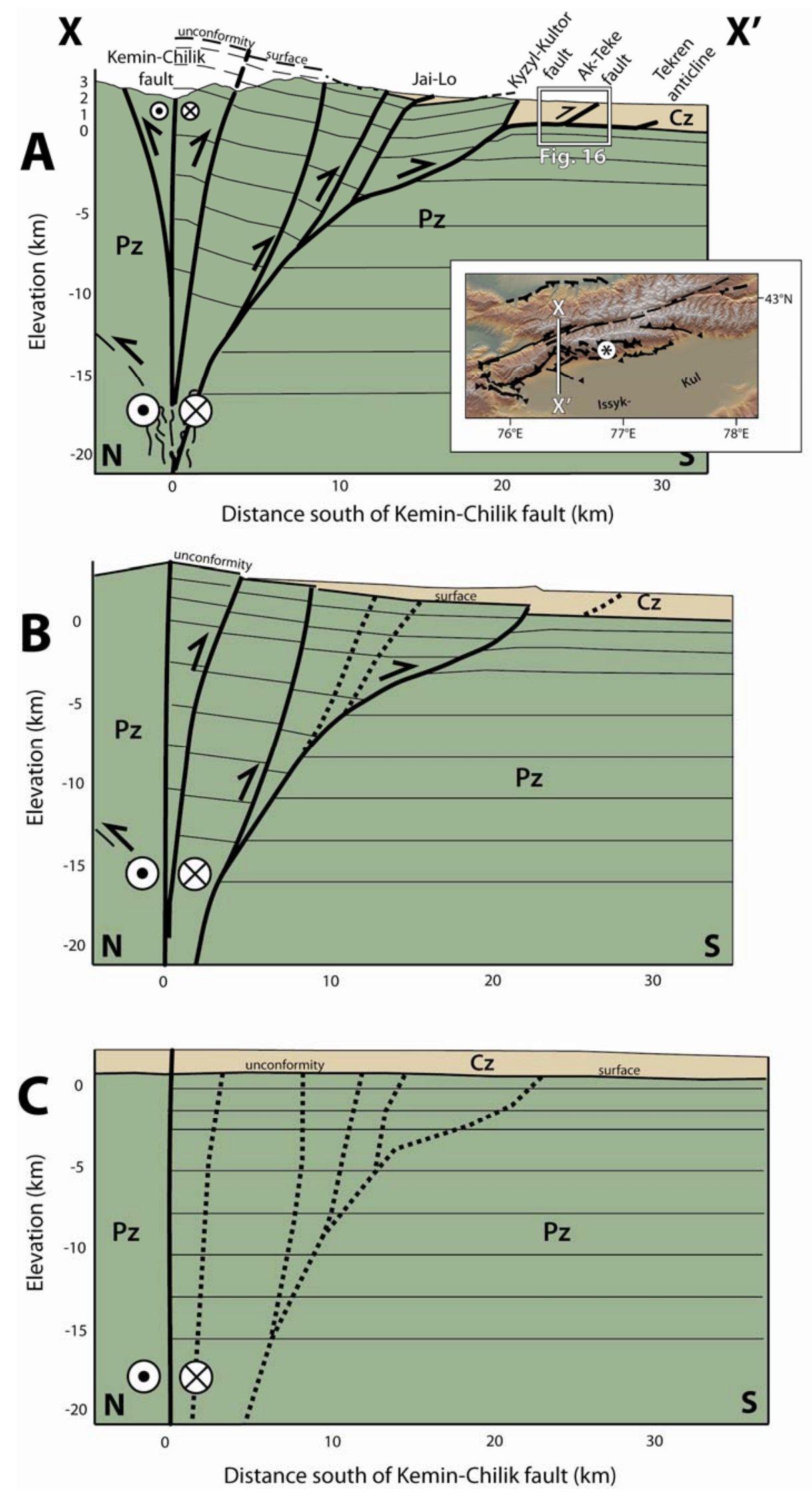
Figure 15. (A) Balanced cross-section through the Toru-Aygir River valley and Kungey Range along X-X', shown in the inset and Fig. 4. Major structures are labeled, no vertical exaggeration. Detail of the Ak-Teke fault and tri-shear model is shown in Fig. 16. Inset map shows the location of the cross-section, star indicates the approximate AFT sample location from De Grave et al. (2007) where no reset ages were found. (B) Partial restoration of the section, showing block rotation and minor shape changes. (C) Fully restored section.

Deformation involving Paleozoic basement ceases south of the Kyzyl-Kultor fault, with shortening occurring only in overlying Neogene strata. The Ak-Teke anticline is asymmetric with a broad, flat crest, well documented structural geometry, and overturned bedding on its southern limb. The dip of the north limb of this fold matches the dip of the Ak-Teke fault measured from scarp exposure where the fault displaces multiple generations of fluvial terraces. This coincidence of fault and backlimb dip indicates that the fault soles into a horizontal detachment, which is interpreted to be the gypsum-rich Kokturpak Fm. Because locally overturned beds were observed surrounding the propagating tip of the fault, a trishear model (Erslev, 1991; Allmendinger, 1998) was applied to analyze the geometry of the forelimb of the Ak-Teke fold and fault at depth (Fig. 16). This model results in $\sim 550 \mathrm{~m}$ of slip and, because the fault soles into a horizontal decóllement, an equivalent amount of shortening across the structure.

Shortening and uplift estimates across the Western Kungey Range can be calculated from restoring the cross-section using the unconformity surface as a deformation marker. Shortening and uplift estimates have been made relative to the present position of the unconformity in the footwall of the Ak-Teke fault at $\sim 500 \mathrm{~m}$ elevation (Fig. 15). Areabalancing was used to model the minor changes in shape of basement blocks required to accommodate faulting at depth. Uplift calculated for the core of the range adjacent to the Kemin-Chilik fault is a minimum because the unconformity surface is not preserved at the 


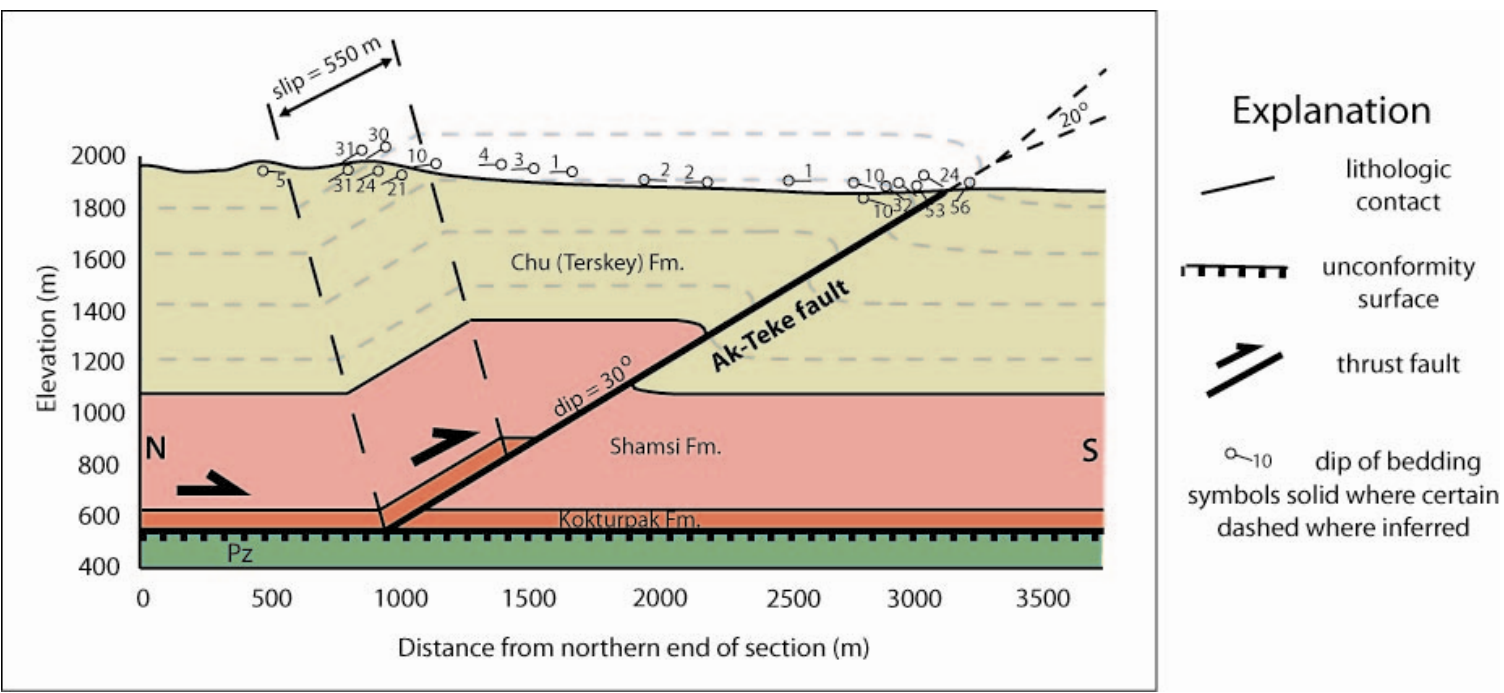

Figure 16. Detailed cross-section of the Ak-Teke anticline constructed using a tri-shear model (Erslev, 1991; Allmendinger, 1998) allowing for the gypsum-rich Kokturpak Fm. (Tk) to act as a basal decóllment. No vertical exaggeration.

range crest. Restoration of the cross-section and including folding across the Ak-Teke anticline shows that $5 \pm 1 \mathrm{~km}$ of shortening has been accommodated across the western Kungey Range. Uplift of the range is highest closest to the Kemin-Chilik Fault, where $>5 \mathrm{~km}$ of rock uplift relative to the undeformed unconformity surface beneath the Ak-Teke anticline has taken place. This amount decreases to the south, where the basement-cored KyzylKultor hills have only experienced $\sim 2 \mathrm{~km}$ of rock uplift.

\subsubsection{Central Kungey Range}

A second cross-section was constructed through the central Kungey Range east of the town of Cholpon-Ata (Fig. 17). The cross-section was balanced using the same techniques applied to the western Kungey Range. Fault geometries are estimated from well-exposed Neogene strata and exposures of tilted unconformity surface both at the range front and high within the range. With the exception of the southern limb of the Cholpon-Ata syncline, the exhumed unconformity surface dips south $25-30^{\circ}$, indicating a major concave-down fault at 

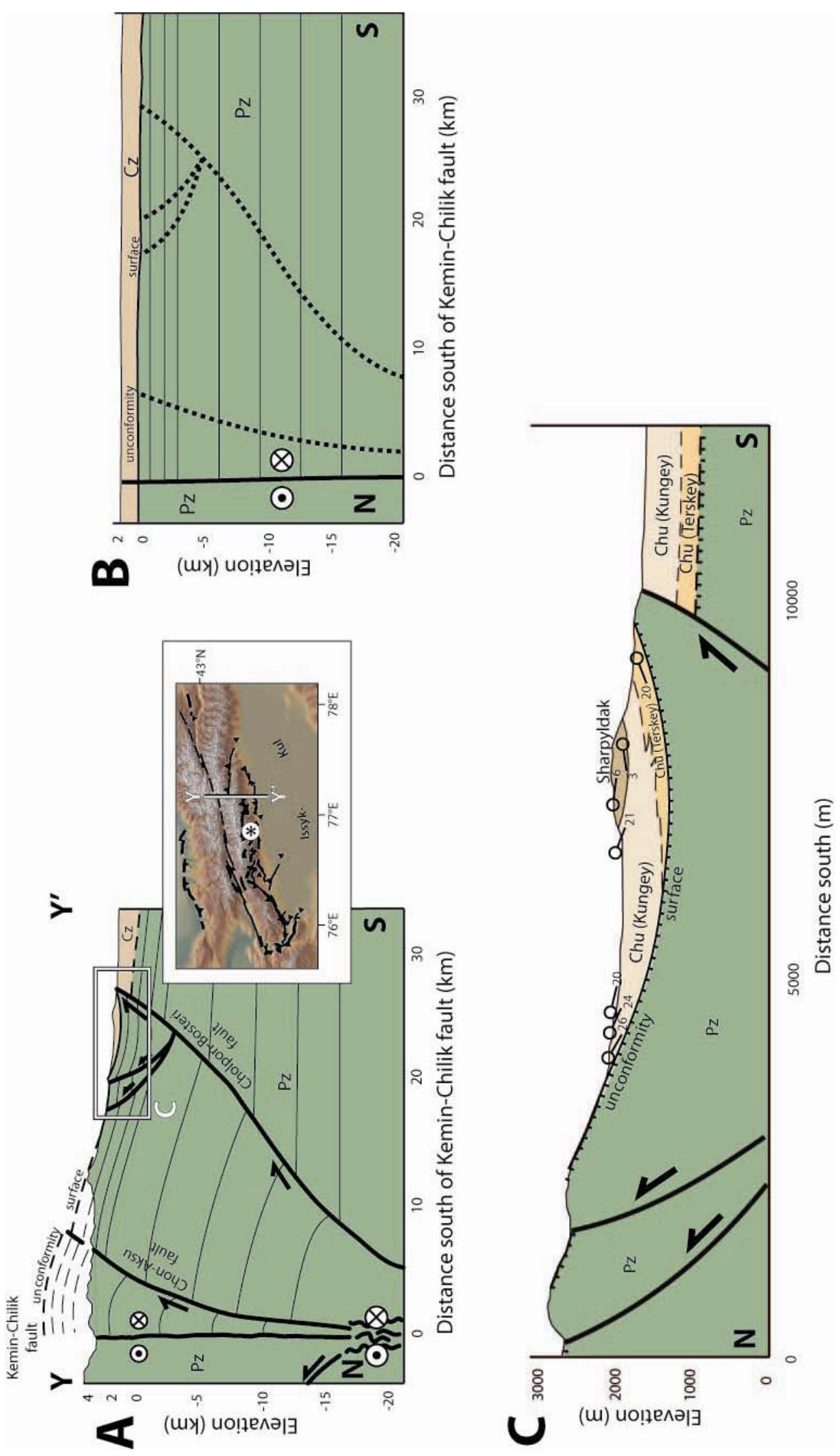
Figure 17. (A) Balanced cross-section through the central Kungey Range, line Y-Y' noted in the inset and Fig. 8. Major structures are labeled, no vertical exaggeration. Inset map shows the location of Y-Y' and AFT sample locations from De Grave et al. (2007). (B) Fully restored section, no vertical exaggeration. (C) Detailed cross-section through the Cholpon-Ata syncline. No vertical exaggeration.

depth (Erslev, 1986). Rooting into this fault is a set of north-vergent backthrusts bounding the northern limb of the Cholpon-Ata syncline.

The unconformity surface is again used as a deformation marker to restore the crosssection through the Central Kungey Range. Because it is not directly possible to measure the position of the unconformity surface in the footwall of the central Kungey Range, the same position as the footwall unconformity surface in the western Kungey Range is assumed at $\sim 500$ m elevation. Restoration of the cross-section indicates $4 \pm 1 \mathrm{~km}$ of shortening across the Central Kungey Range. Although this amount is less than the shortening in the Western Kungey Range, higher topographic elevations indicate that a greater amount of uplift is likely to have taken place. From restoration of the cross-section $\sim 6 \mathrm{~km}$ of uplift is estimated relative to the inferred position of the unconformity surface at the northern margin of the Issyk-Kul basin. Fission track studies of the Kungey Range (De Grave et al., 2007) (Figure 17) show an absence of reset ages between the western and central Kungey cross-sections. Assuming a closure temperature of $110^{\circ} \mathrm{C}$ for apatite fission tracks and a geotherm of 25$30^{\circ} \mathrm{C} / \mathrm{km}$ (Sobel et al., 2006; De Grave et al., 2007), a maximum of $\sim 4 \mathrm{~km}$ of incision into the unconformity surface is allowed. This places an upper limit on the amount of rock uplift at the range crest.

\subsubsection{Range growth}

The Kemin-Chilik fault is one of many inherited structures that play a role in the growth of the Tian Shan (e.g. De Grave et al., 2007). Inheritance of the Kemin-Chilik fault is 
demonstrated by offset of Paleozoic basement terranes (Delvaux et al, 1999). Minor late Cenozoic motion is of the same sense as these Paleozoic offsets, and thus does not by itself accomplish range uplift. Growth of the northern Tian Shan has instead taken place via a newly formed reverse fault network that surrounds the inherited strike-slip fault. Evidence that these faults are newly formed includes basement offsets that are consistent with late Quaternary deformation, and no juxtaposition of contrasting Paleozoic terranes across members of this fault network.

The cross-sections (Fig. 15 and Fig. 17) demonstrate the pattern of structural growth characteristic of the Kungey Range. Using the pre-Cenozoic unconformity surface as a deformation marker, there is a north-to-south decrease in rock uplift developed on reverse faults within the range. Steeply-dipping reverse faults in the core of the range display the greatest amount of slip, which corresponds to the regions of maximum topography and little preservation of the unconformity surface in the landscape. Faults at the southern margin of the Kungey Range display smaller amounts of slip, though the majority of horizontal shortening has taken place along these faults. This pattern of greater uplift in the range core and shortening along the margin is most consistent with a network of concave-down faults rooting into a steeply-dipping shear zone coincident with the Kemin-Chilik fault at depth.

Comparison of net structural growth to the distribution of active structures illustrates a complex, but overall southward-stepping pattern of deformation in the western Kungey Range. The most denuded portions of the range lie in its core, adjacent to the Kemin-Chilik fault. These areas are likely also the earliest-formed parts of the range, providing granitic sediments that make up the Kungey member of the Chu Fm. in exposures uplifted along the range margin. The Kyzyl-Kultor Fault that bounds the southern limb of the Jai-Lo syncline 
does not deform any member of the preserved terrace chronosequence. This indicates that the fault has not been active in the past $140 \mathrm{ka}$. In this area deformation has largely stepped southward into the Issyk-Kul basin, where the Ak-Teke fault and Tekren anticline deform Neogene strata and late Quaternary alluvial surfaces. However, some active deformation also occurs in the Jai-Lo syncline, showing that some active out-of-sequence deformation accommodates overall growth of the Kungey Range.

Deformation in the central Kungey Range displays a similar pattern of north-to-south propagation, although here active faults are also recognized within the range. Stratigraphic evidence shows that prior to deposition of the Sharpyldak Fm. deformation occurred proximal to the Kemin-Chilik fault. Later deformation has stepped southward to the range front. Active faults today include both the Kemin-Chilik fault and Chon-Aksu faults within the range (Delvaux et al., 2001; Arrowsmith et al., 2004; Crosby et al., 2005, 2007), and the range-bounding Cholpon-Bosteri fault.

\subsection{Comparison of long-term and late Quaternary deformation}

Comparison of late Quaternary deformation rates to net shortening further illustrates the pattern of uplift that formed the Kungey and Zailiskey Ranges. Using structural shortening estimates and the stratigraphic interpretation that growth initiated between 7 and 4 Ma gives long-term shortening rates between 0.5 and $1.4 \mathrm{~mm} / \mathrm{yr}$ for the western Kungey Range and 0.4 to $1.2 \mathrm{~mm} / \mathrm{yr}$ in the central Kungey Range. Summing north-south late Quaternary shortening rates along the Toru-Aygir river valley in the western Kungey Range and allowing for minor shortening on additional structures in the Jai-Lo syncline adds to modern shortening of $\sim 1.2 \pm 0.1 \mathrm{~mm} / \mathrm{yr}$, similar to the long-term rate. Since not all faults in the western Kungey Range are currently active and the shortening rate appears to have 
remained approximately constant over time, shortening in the western Kungey Range is interpreted to be partitioned on to separate sets of faults with activity that varies over $\sim 100 \mathrm{ka}$ timescales. In contrast to the western Kungey Range, long-term and late Quaternary shortening rates may not agree in the central Kungey Range. Although modern shortening at the central Kungey Range front is $\sim 0.3 \pm 0.1 \mathrm{~mm} / \mathrm{yr}$, activity along the Chon-Aksu fault (Delvaux et al., 1999) could account for the discrepancy between modern and long-term shortening rates.

Opposing gradients in deformation rate are observed along the Kungey and Zailiskey range fronts. Shortening rates in the Kungey Range are highest in the west and decrease to essentially zero in the east. Though thick loess cover obscures much of the Quaternary record along the central and eastern Zailiskey Range front, deformation rates inferred from deformed terrace markers and exposures of Neogene strata appear highest in the eastern half of the range front.

\subsection{The role of strike-slip faulting in shortening of the northern Tian Shan}

Intracontinental strike-slip faults in convergent orogens have generally been thought to act as transform faults, shunting deformation from one part of the orogen to another (e.g. Molnar and Tapponnier, 1975). Major strike-slip faults bounding the Tibetan plateau, such as the Altyn-Tagh and Karakorum faults have been held as type examples, though fierce debate surrounds this interpretation (Fig. 1) (e.g. Lacassin et al., 2004; Chevalier et al., 2005; Cowgill, 2007). The pattern of shortening in the Kungey and Zailiskey Ranges is geometrically opposite of what would be expected for the absorption of slip at the ends of a sinistral transform fault (Fig. 18a). Instead, shortening is absorbed via east-west striking reverse faults located along and stepping outward from the axial strike-slip fault. Thus, 
rather than acting as a transform, it appears that the Kemin-Chilik fault acts as a central member of a dominantly north-south contractional system. Because the Kemin-Chilik fault remains embedded within the Kungey and Zailiskey Ranges, what sinistral motion does take place along the fault must be absorbed somehow along its length. We suggest that instead of shortening at the fault tips, sinistral motion is absorbed by rotation and oroclinal folding of the fault trace, commensurate with gradients in shortening along the range margins (Fig. 18b).
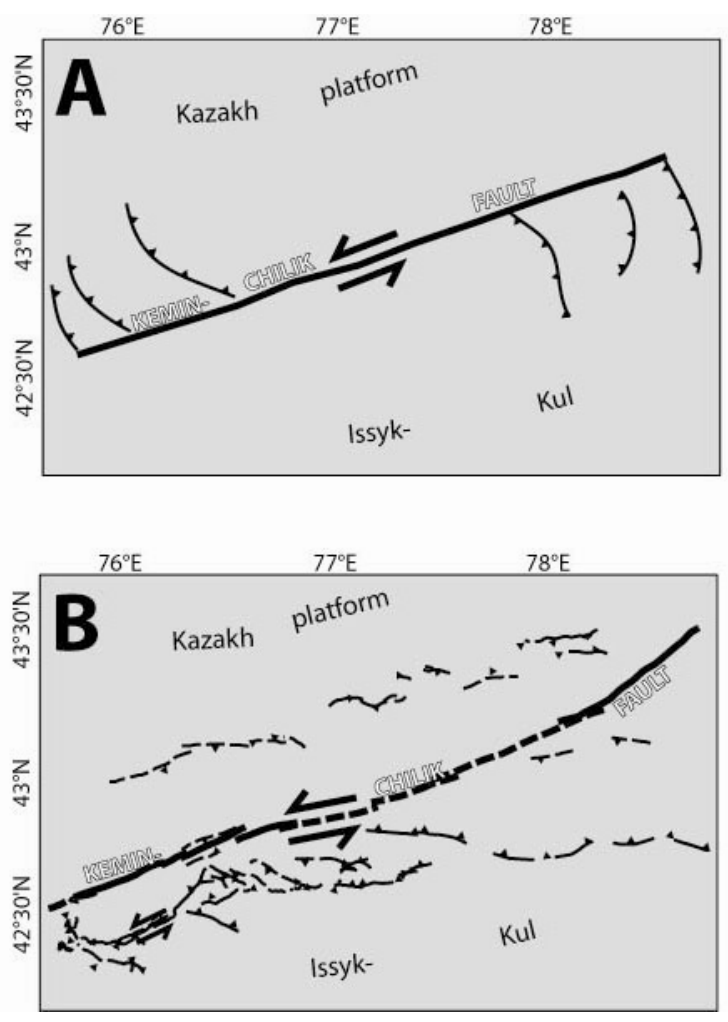

Figure 18. (A) Schematic diagram showing expected faulting at the tips of a sinistral strike-slip fault acting as a transform. Material is moved along the fault into fold and thrust belts that emanate outward from the fault tips. (B) Observed fault geometry of the northern Tian Shan. Shortening is accomplished along roughly east-west striking reverse faults that are sub-parallel to the KeminChilik fault and located on the opposite side than is expected for a transform fault. Sinistral strike-slip deformation plays a larger role in the western Kungey Range where the Kemin-Chilik fault is oriented $\sim 60^{\circ}$ to north-south convergence. At $\sim 76^{\circ} 15^{\prime}$ E the KeminChilik fault bends to become almost orthogonal to overall convergence and reverse motion rather than strike-slip motion plays a larger role in range growth.

The pattern of reverse faulting surrounding an inherited strike-slip fault we observe in the Kungey and Zailiskey Ranges appears elsewhere in BITB with embedded strike-slip faults. For example, numerous strike-slip faults embedded within the Zagros Plateau absorb 
shortening via networks of reverse faults that have developed surrounding the axial strikeslip fault (Allen et al., 2006). Another example is the Kunlun fault, where a slip rate study by Kirby et al. (2007) showed that slip is absorbed gradually along strike through formation of shortening structures.

\subsection{Implications for the development of high-angle basement-involved reverse faults}

The reactivation of pre-existing, steeply dipping faults oriented oblique to the shortening direction could be a common mechanism for the production of new high-angle reverse faults in basement-involved thrust belts (BITB). A pre-existing, high-angle fault zone in the crust may preferentially re-activate despite non-optimal orientation to overall compression (Webb and Johnson, 2006). Following initial re-activation, a network of highangle reverse faults rooting into the central steeply dipping fault may develop to accommodate continued shortening. This geometry is commonly observed in transpressional regimes where restraining bends along major strike-slip faults produce steeply dipping reverse fault networks (e.g. Cunningham et al., 1996; Ding et al., 2004; Vassallo et al., 2007). However, this geometry has not been proposed in regions where lateral motion along the strike-slip fault only plays a minor role. Within the framework of the northern Tian Shan, sinistral motion along the Kemin-Chilik fault has not played a major role in the shortening of the Kungey and Zailiskey Ranges. What little late Cenozoic slip along the Kemin-Chilik fault that has occurred is absorbed along its length. The more important role of the Kemin-Chilik fault zone appears to be that it acts as a nucleation point for the numerous high-angle reverse faults responsible for range growth and shortening. 
The pattern of steeply dipping reverse faults emanating outward from a central, inherited strike-slip fault fits very well with the predictions of a mechanical model of slip partitioning (Bowman et al., 2003). Here, the obliquely-oriented Kemin-Chilik fault accommodates transpression at depth, with deformation propagating upwards as a partitioned system in response to convergence. Models developed by Bowman et al. (2003) use a rectangular, oblique elastic dislocation (Okada, 1985) along a steeply-dipping fault at depth. Their model predicts that for oblique motion at depth, deformation will propagate upwards as a partitioned system of strike-slip and oblique-slip faults. Because fault geometries and slip are better understood in the Kungey Range than the Zailiskey Range, the model of Bowman et al. (2003) is compared only to faulting associated with uplift of the Kungey Range. A combination of models with modestly varying ratios of strike-slip to reverse motion fits well with the observed faulting of the western and central Kungey Range (Fig. 19). For the western part of the range, greater strike-slip than reverse motion is inferred where the Kemin-Chilik is oriented $\sim 60^{\circ}$ oblique to north-south compression. This model accurately predicts sinistral motion along both the Kemin-Chilik and Toguz-Bulak faults. Where the Kemin-Chilik fault is oriented $>60^{\circ}$ from the northsouth compression direction, the reverse component of the modeled slip is greater than the strike-slip component. This model predicts the observed strike and dip of reverse faults within the range and along the range front. The model also successfully predicts the overall cross-section geometry of these faults (Fig. 19). Faults high in the range are steeply dipping, while those further away from the Kemin-Chilik fault dip less and accommodate more shortening. The entire fault network roots concave-downward into a central shear zone co-located with the Kemin-Chilik fault. 

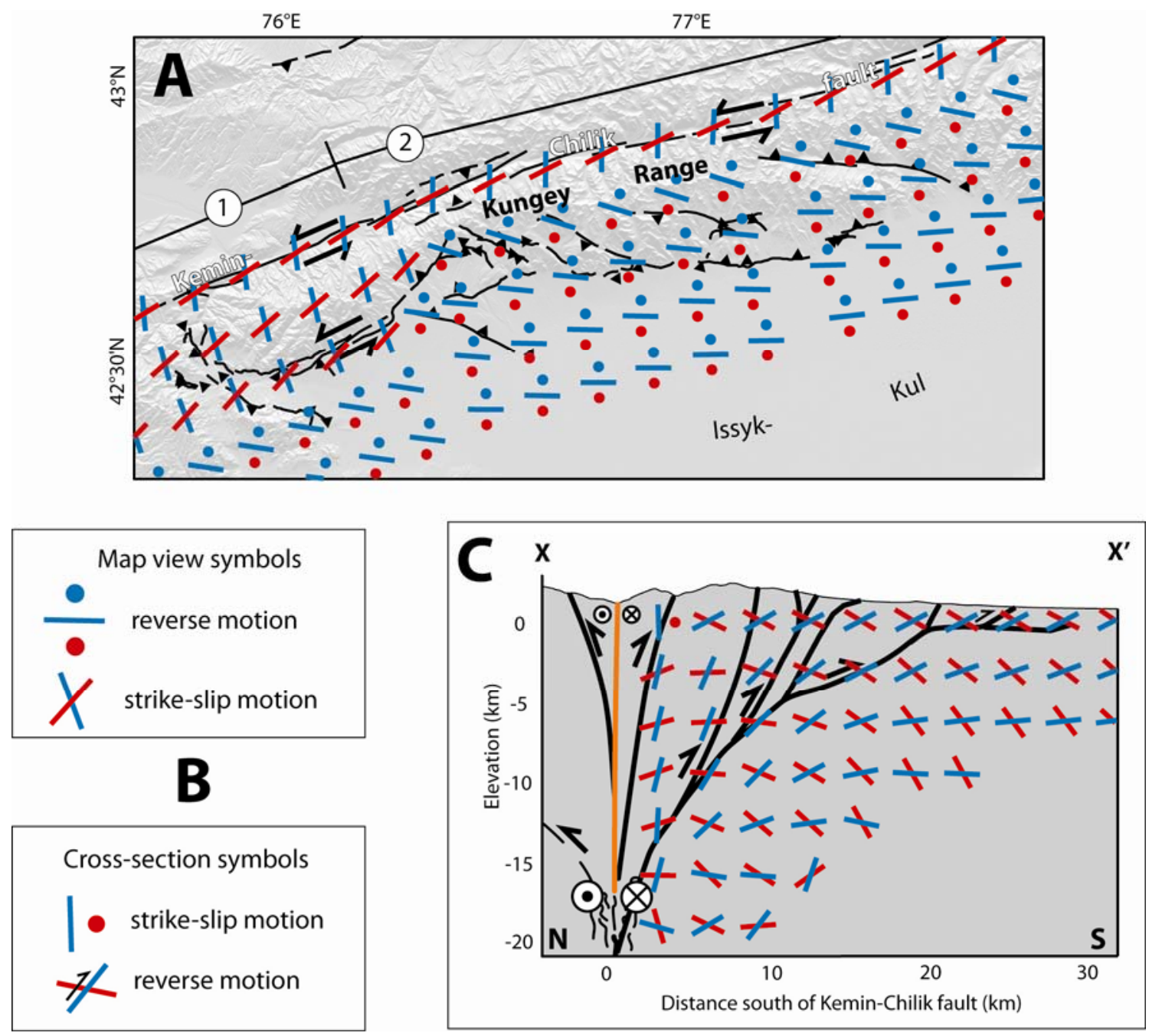

Figure 19. (A) Slip partitioning model (using models from Bowman et al. (2003)) for the western and central Kungey Range compared to observed fault geometry. For this model, the Kungey Range was divided into two segments with varying reverse to strikeslip motion ratios to find a best fit. Segment 1 has a 0.6:1.0 reverse to strike-slip ratio, and segment 2 uses a $1.0: 0.6$ reverse to strike-slip ratio. (B) Representations of failure planes using the notation of Bowman et al. (2003). In map view, solid lines indicate intersections of predicted fault planes with the surface. For reverse motion, blue lines note the predicted fault strike. Blue and red dots indicate hanging walls for south- and north-verging faulting, respectively. Red and blue lines for strike-slip motion represent predicted fault traces, with red indicating sinistral motion and blue dextral motion. In cross-section view, solid lines indicate intersections of predicted fault planes with the vertical section line. Strike-slip motion is indicated by a single line with a red dot indicating sinistral motion into the plane of section. Reverse motion is denoted by red and blue lines showing predicted fault orientations. (C) Cross-section slip partitioning model along cross-section line $\mathrm{X}-\mathrm{X}^{\prime}$, shown in Fig. 14. For this comparison, a 1.0 : 0.6 reverse to strike-slip ratio model was used with a $75^{\circ}$ dipping fault at depth, the tip of which is co-located with the Kemin-Chilik fault at $20 \mathrm{~km}$ depth. The re-activated KeminChilik fault is colored orange in the figure. 


\section{Conclusions}

The development of high-angle reverse faults commonly found in basement-cored uplifts poses problems, as these faults violate mechanical predictions for the initiation of thrust or reverse faults, and absorbing shortening on high-angle structures is kinematically unfavorable (Anderson, 1959; Sibson, 1985). Reactivation of pre-existing strike-slip faults and the initiation of new faults in the surrounding crust may provide an explanation for the existence of these high-angle reverse faults. Inherited strike-slip faults can act as nucleation points, where oblique deformation at depth can propagate upwards as a partitioned system of reverse and obliquely-slipping faults (Molnar, 1992; Bowman et al., 2003). This network of neoformed faults can be described as a positive mega-flower structure with concave-down faults emanating from a central shear zone.

The Kungey and Zailiskey Ranges of the northern Tian Shan are dominated by curviplanar reverse and oblique faults whose dips increase at depth to root into the central Kemin-Chilik fault zone. Mechanical models of slip partitioning (Bowman et al., 2003) accurately predict the observed fault geometries at depth and on the surface. Growth of the ranges, deduced from structural and stratigraphic evidence, took place as these fault networks developed, propagating outward from the Kemin-Chilik fault. At present, the geometry of the northern Tian Shan can be described using a mega-flower structure, with active deformation in the core of the range and at its margins. Because many other ranges within the Tian Shan are cored by inherited strike-slip faults, this growth model may apply 
elsewhere within the orogen, and provide an explanation for the origin of high-angle reverse faults in basement-involved uplifts. 


\section{Appendix A: Paleocurrent measurements}

\begin{tabular}{|c|c|c|c|c|c|c|c|}
\hline Easting $^{a}$ & Northing $^{a}$ & Unit $^{\mathrm{b}}$ & transport azimuth* & Easting $^{a}$ & Northing $^{a}$ & Unit $^{\mathrm{b}}$ & transport azimuth* \\
\hline \multicolumn{2}{|l|}{ Toru-Aygir } & & & \multicolumn{2}{|l|}{ Toru-Aygir } & & \\
\hline 615395 & 4716412 & $\mathrm{Tc}(\mathrm{t})$ & 353 & 615915 & 4715316 & $\mathrm{Tc}(\mathrm{t})$ & 334 \\
\hline 615411 & 4716404 & $\mathrm{Tc}(\mathrm{t})$ & 323 & 615935 & 4715325 & $\mathrm{Tc}(\mathrm{t})$ & 309 \\
\hline 615382 & 4716410 & $T c(t)$ & 332 & 616046 & 4715215 & $\mathrm{Tc}(\mathrm{t})$ & 310 \\
\hline 615335 & 4716359 & $\mathrm{Tc}(\mathrm{t})$ & 18 & 616373 & 4714948 & $\mathrm{Tc}(\mathrm{t})$ & 13 \\
\hline 615354 & 4716351 & $T c(t)$ & 22 & 616415 & 4714899 & $\mathrm{Tc}(\mathrm{t})$ & 25 \\
\hline 615340 & 4716341 & $T c(t)$ & 342 & 616327 & 4714853 & $T c(t)$ & 348 \\
\hline 615322 & 4716339 & $T c(t)$ & 350 & 616281 & 4714663 & $\mathrm{Tc}(\mathrm{t})$ & 350 \\
\hline 615315 & 4716340 & $T c(t)$ & 35 & 616294 & 4714065 & $\mathrm{Tc}(\mathrm{t})$ & 13 \\
\hline 615268 & 4716320 & $\mathrm{Tc}(\mathrm{t})$ & 14 & 616246 & 4714135 & $\mathrm{Tc}(\mathrm{t})$ & 22 \\
\hline 615263 & 4716309 & $T c(t)$ & 5 & 616207 & 4714228 & $T c(t)$ & 354 \\
\hline 615263 & 4716280 & $T c(t)$ & 25 & 616082 & 4714154 & $T c(t)$ & 25 \\
\hline 615304 & 4716259 & $T c(t)$ & 351 & 616060 & 4714166 & $T c(t)$ & 16 \\
\hline 615320 & 4716250 & $T c(t)$ & 4 & 615969 & 4714254 & $\mathrm{Tc}(\mathrm{t})$ & 355 \\
\hline 615323 & 4716235 & $\mathrm{Tc}(\mathrm{t})$ & 306 & 615995 & 4714193 & $\mathrm{Tc}(\mathrm{t})$ & 351 \\
\hline 615357 & 4716193 & $T c(t)$ & 325 & 615929 & 4714156 & $\mathrm{Tc}(\mathrm{t})$ & 248 \\
\hline 615406 & 4716156 & $T c(t)$ & 336 & 615882 & 4714128 & $\mathrm{Tc}(\mathrm{t})$ & 334 \\
\hline 615394 & 4716149 & $T c(t)$ & 5 & 615906 & 4714115 & $\mathrm{Tc}(\mathrm{t})$ & 36 \\
\hline 615404 & 4716124 & $T c(t)$ & 15 & 615847 & 4714160 & $\mathrm{Tc}(\mathrm{t})$ & 6 \\
\hline 615906 & 4716033 & $T c(t)$ & 12 & 615826 & 4714177 & $T c(t)$ & 360 \\
\hline 615876 & 4715992 & $T c(t)$ & 23 & 615879 & 4714195 & $T c(t)$ & 2 \\
\hline 615868 & 4715985 & $T c(t)$ & 210 & 615923 & 4714232 & $\mathrm{Tc}(\mathrm{t})$ & 348 \\
\hline 615750 & 4715997 & $T c(t)$ & 9 & 615845 & 4715387 & $\mathrm{Tc}(\mathrm{t})$ & 215 \\
\hline 615733 & 4715969 & $T c(t)$ & 317 & 615846 & 4715387 & $T c(t)$ & 313 \\
\hline 615728 & 4715948 & $T c(t)$ & 325 & & & & \\
\hline 615623 & 4715600 & $\mathrm{Tc}(\mathrm{t})$ & 330 & Cholpon-Ata & & & \\
\hline 615631 & 4715601 & $T c(t)$ & 15 & 676391 & 4726736 & $\mathrm{Tc}(\mathrm{t})$ & 340 \\
\hline 615632 & 4715562 & $T c(t)$ & 355 & 676382 & 4726740 & $\mathrm{Tc}(\mathrm{t})$ & 327 \\
\hline 615656 & 4715538 & $\mathrm{Tc}(\mathrm{t})$ & 320 & 676383 & 4726737 & $\mathrm{Tc}(\mathrm{t})$ & 6 \\
\hline 615634 & 4715474 & $\mathrm{Tc}(\mathrm{t})$ & 346 & 707144 & 4737788 & $\mathrm{Tc}(\mathrm{t})$ & 281 \\
\hline \multicolumn{8}{|c|}{${ }^{a}$ Coordinate system: WGS 1984 UTM zone 43 N } \\
\hline Units: $\mathrm{Tc}(\mathrm{t})$ & Fm., Tersk & - & ngey) & & & & \\
\hline
\end{tabular}




\section{Appendix A (continued)}

\begin{tabular}{|c|c|c|c|c|c|c|c|}
\hline Easting $^{a}$ & Northing $^{a}$ & Unit $^{\mathrm{b}}$ & transport azimuth* & Easting $^{a}$ & Northing $^{a}$ & Unit $^{b}$ & transport azimuth* \\
\hline \multicolumn{2}{|l|}{ Cholpon-Ata } & & & \multicolumn{2}{|c|}{ Cholpon-Ata } & & \\
\hline 691767 & 4730155 & $\mathrm{Tc}(\mathrm{t})$ & 346 & 673221 & 4725575 & $\mathrm{Tc}(\mathrm{k})$ & 192 \\
\hline 691767 & 4730156 & $\mathrm{Tc}(\mathrm{t})$ & 341 & 673207 & 4725632 & $\mathrm{Tc}(\mathrm{k})$ & 160 \\
\hline 691767 & 4730139 & $\mathrm{Tc}(\mathrm{t})$ & 5 & 673196 & 4725665 & $\mathrm{Tc}(\mathrm{k})$ & 168 \\
\hline 691765 & 4730134 & $\mathrm{Tc}(\mathrm{t})$ & 1 & 674281 & 4724910 & $\mathrm{Tc}(\mathrm{k})$ & 206 \\
\hline 691765 & 4730127 & $\mathrm{Tc}(\mathrm{t})$ & 13 & 674309 & 4724934 & $\mathrm{Tc}(\mathrm{k})$ & 163 \\
\hline 691683 & 4730266 & $\mathrm{Tc}(\mathrm{t})$ & 356 & 674408 & 4725023 & $\mathrm{Tc}(\mathrm{k})$ & 200 \\
\hline 691514 & 4730413 & $\mathrm{Tc}(\mathrm{t})$ & 355 & 674442 & 4725060 & $\mathrm{Tc}(\mathrm{k})$ & 218 \\
\hline 691512 & 4730404 & $\mathrm{Tc}(\mathrm{t})$ & 17 & 674457 & 4725075 & $\mathrm{Tc}(\mathrm{k})$ & 224 \\
\hline 691483 & 4730457 & $\mathrm{Tc}(\mathrm{t})$ & 340 & 674460 & 4725071 & $\mathrm{Tc}(\mathrm{k})$ & 224 \\
\hline 691479 & 4730462 & $\mathrm{Tc}(\mathrm{t})$ & 310 & 674422 & 4725102 & $\mathrm{Tc}(\mathrm{k})$ & 210 \\
\hline 691422 & 4730505 & $\mathrm{Tc}(\mathrm{t})$ & 20 & 674432 & 4725117 & $\mathrm{Tc}(\mathrm{k})$ & 214 \\
\hline 691483 & 4730655 & $\mathrm{Tc}(\mathrm{t})$ & 348 & 674429 & 4725117 & $\mathrm{Tc}(\mathrm{k})$ & 239 \\
\hline 691488 & 4730660 & $\mathrm{Tc}(\mathrm{t})$ & 352 & 674432 & 4725116 & $\mathrm{Tc}(\mathrm{k})$ & 210 \\
\hline 691483 & 4730668 & $\mathrm{Tc}(\mathrm{t})$ & 355 & 674464 & 4725133 & $\mathrm{Tc}(\mathrm{k})$ & 232 \\
\hline 691490 & 4730653 & $\mathrm{Tc}(\mathrm{t})$ & 320 & 674445 & 4725148 & $\mathrm{Tc}(\mathrm{k})$ & 193 \\
\hline 691597 & 4730621 & $T c(t)$ & 300 & 674447 & 4725155 & $\mathrm{Tc}(\mathrm{k})$ & 236 \\
\hline 691670 & 4730550 & $\mathrm{Tc}(\mathrm{t})$ & 345 & 674386 & 4725361 & $\mathrm{Tc}(\mathrm{k})$ & 200 \\
\hline 691697 & 4730562 & $\mathrm{Tc}(\mathrm{t})$ & 19 & 674391 & 4725432 & $\mathrm{Tc}(\mathrm{k})$ & 186 \\
\hline 691691 & 4730527 & $\mathrm{Tc}(\mathrm{t})$ & 25 & 674402 & 4725455 & $\mathrm{Tc}(\mathrm{k})$ & 168 \\
\hline 673541 & 4725529 & $\mathrm{Tc}(\mathrm{k})$ & 199 & 674396 & 4725454 & $\mathrm{Tc}(\mathrm{k})$ & 186 \\
\hline 673517 & 4725567 & $\mathrm{Tc}(\mathrm{k})$ & 161 & 674406 & 4725478 & $\mathrm{Tc}(\mathrm{k})$ & 168 \\
\hline 673512 & 4725591 & $\mathrm{Tc}(\mathrm{k})$ & 191 & 674420 & 4725523 & $\mathrm{Tc}(\mathrm{k})$ & 222 \\
\hline 673499 & 4725626 & $\mathrm{Tc}(\mathrm{k})$ & 164 & 674415 & 4725529 & $\mathrm{Tc}(\mathrm{k})$ & 191 \\
\hline 673457 & 4725671 & $\mathrm{Tc}(\mathrm{k})$ & 127 & 674234 & 4725949 & $\mathrm{Tc}(\mathrm{k})$ & 239 \\
\hline 673460 & 4725673 & $\mathrm{Tc}(\mathrm{k})$ & 174 & 672958 & 4725249 & $\mathrm{Tc}(\mathrm{k})$ & 200 \\
\hline 673467 & 4725685 & $\mathrm{Tc}(\mathrm{k})$ & 167 & 673234 & 4725568 & $\mathrm{Tc}(\mathrm{k})$ & 201 \\
\hline 673333 & 4725766 & $\mathrm{Tc}(\mathrm{k})$ & 194 & 691770 & 4730166 & $\mathrm{Tc}(\mathrm{t})$ & 350 \\
\hline 673323 & 4725766 & $\mathrm{Tc}(\mathrm{k})$ & 175 & 691771 & 4730159 & $\mathrm{Tc}(\mathrm{t})$ & 6 \\
\hline 673282 & 4725721 & $\mathrm{Tc}(\mathrm{k})$ & 207 & 691778 & 4730170 & $\mathrm{Tc}(\mathrm{t})$ & 12 \\
\hline 673235 & 4725562 & $\mathrm{Tc}(\mathrm{k})$ & 170 & 691775 & 4730167 & $\mathrm{Tc}(\mathrm{t})$ & 315 \\
\hline
\end{tabular}




\section{Appendix B: Structural measurements from the Kungey Range front}

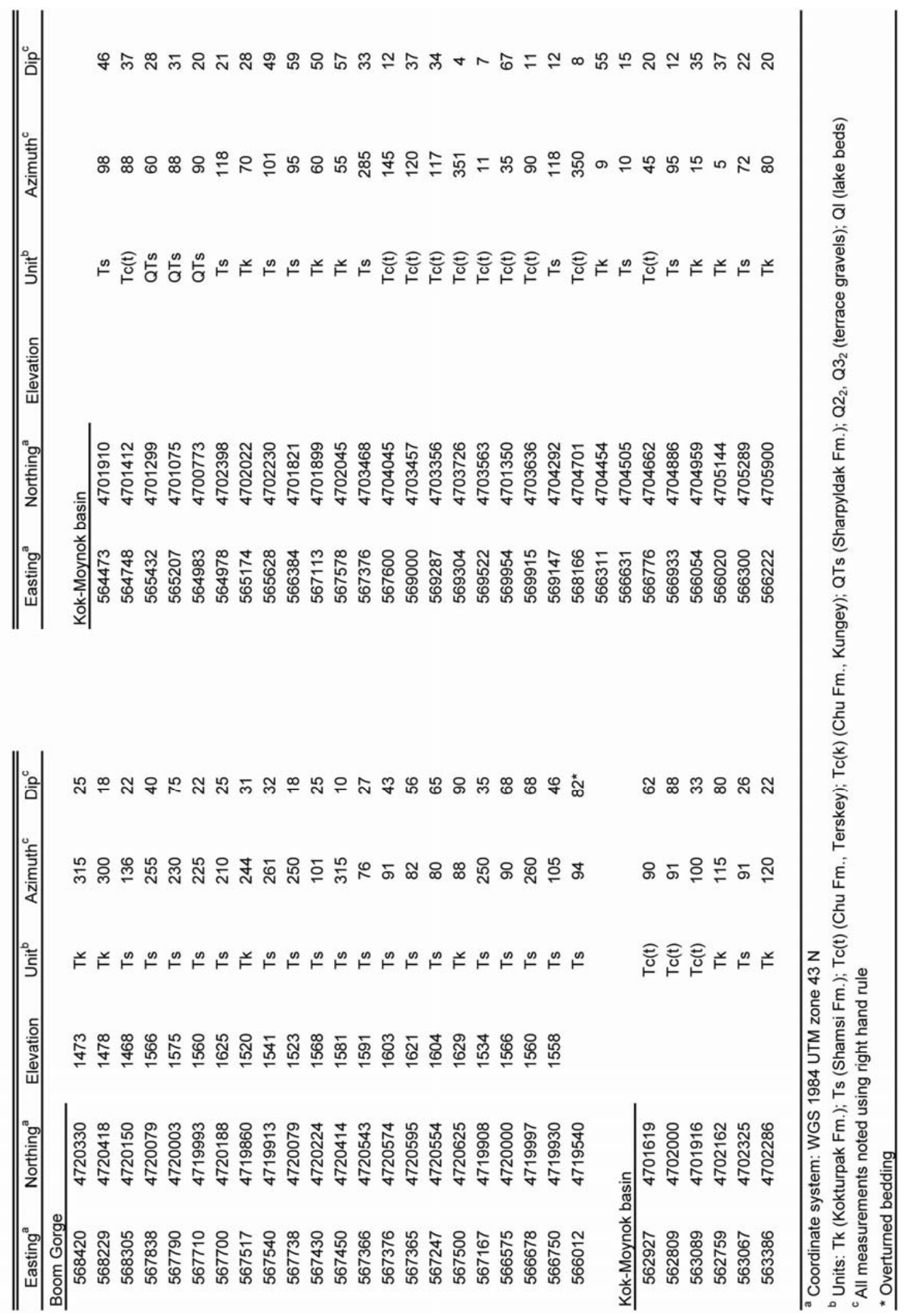




\section{Appendix B (continued)}

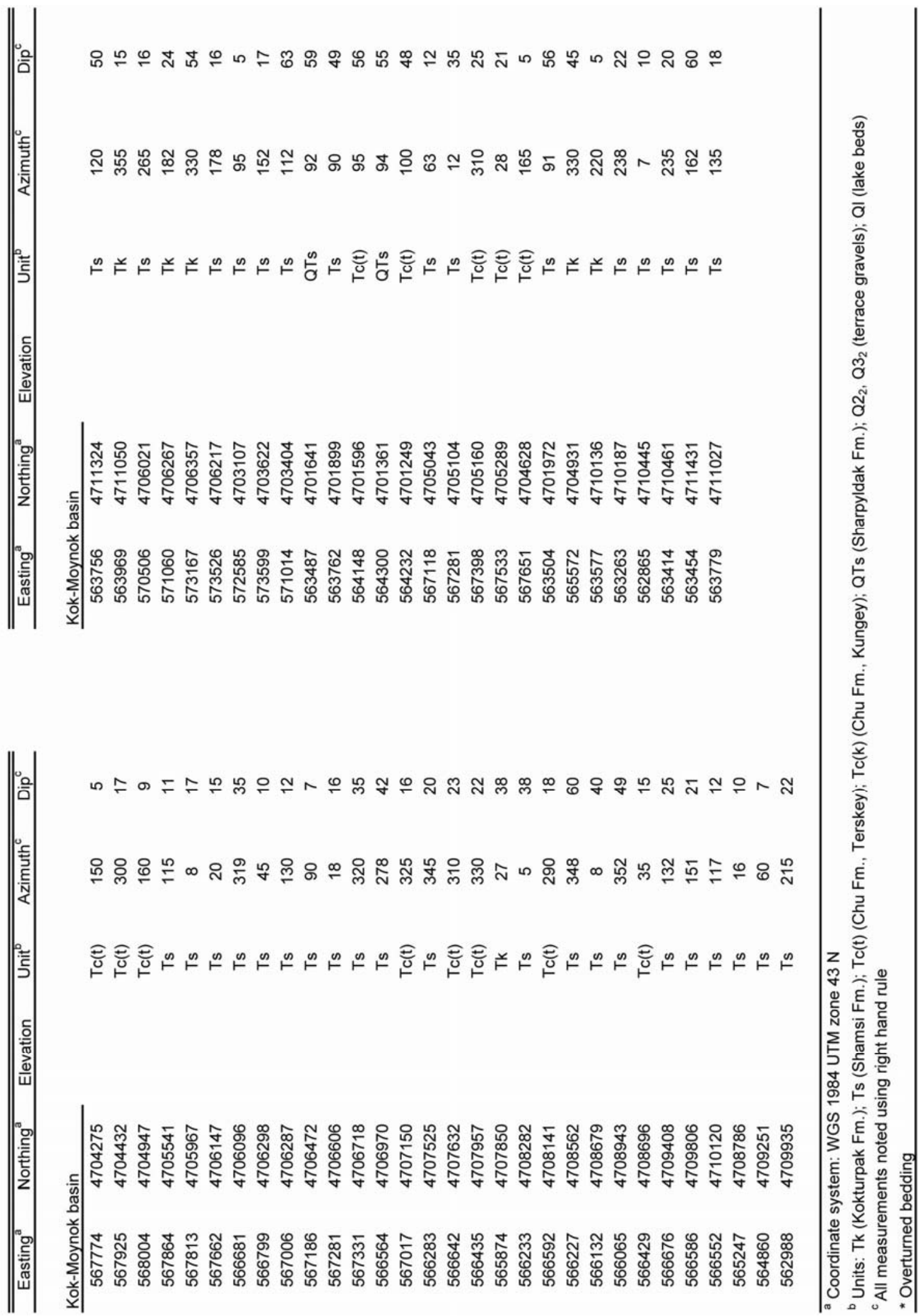




\section{Appendix B (continued)}

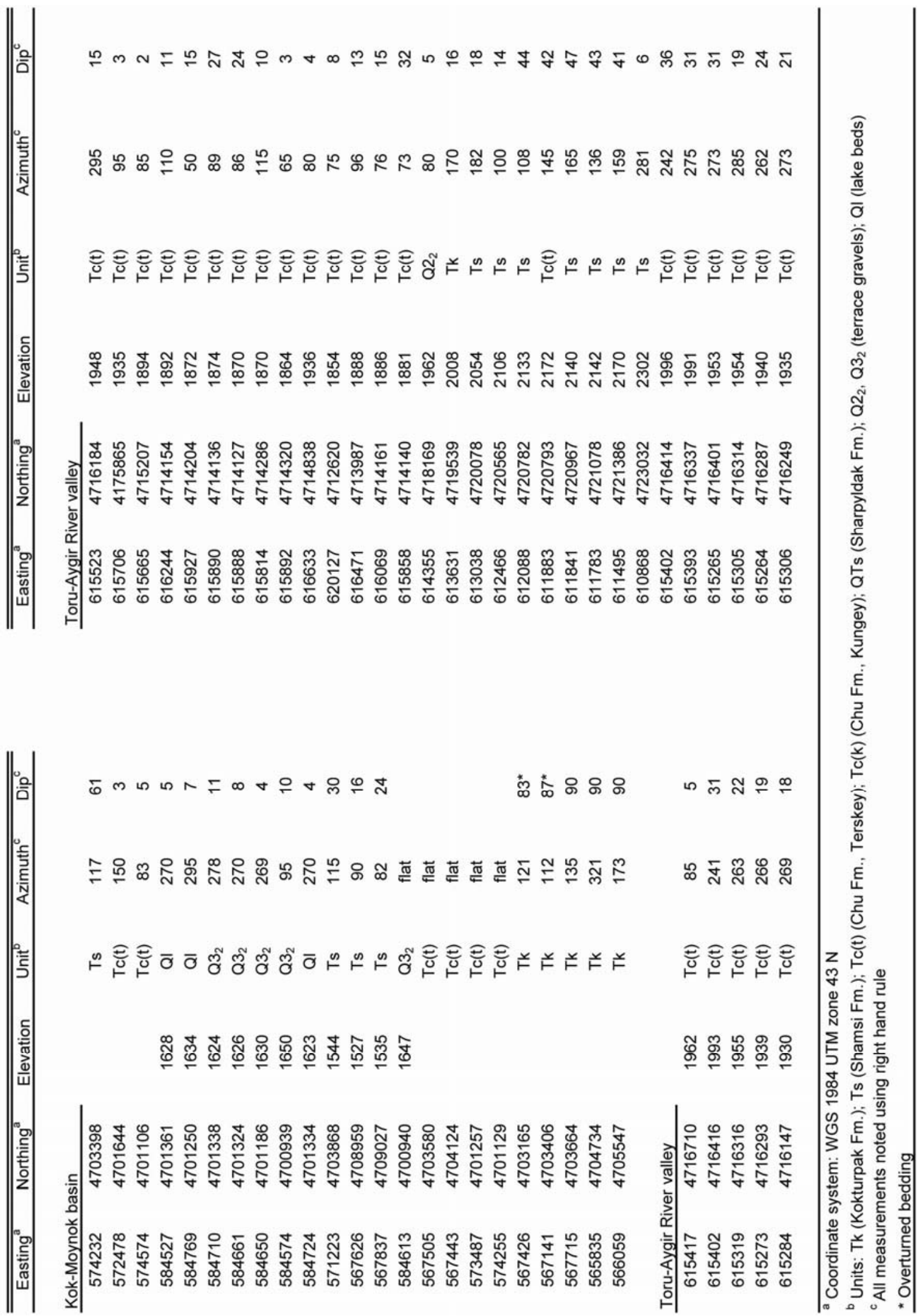




\section{Appendix B (continued)}

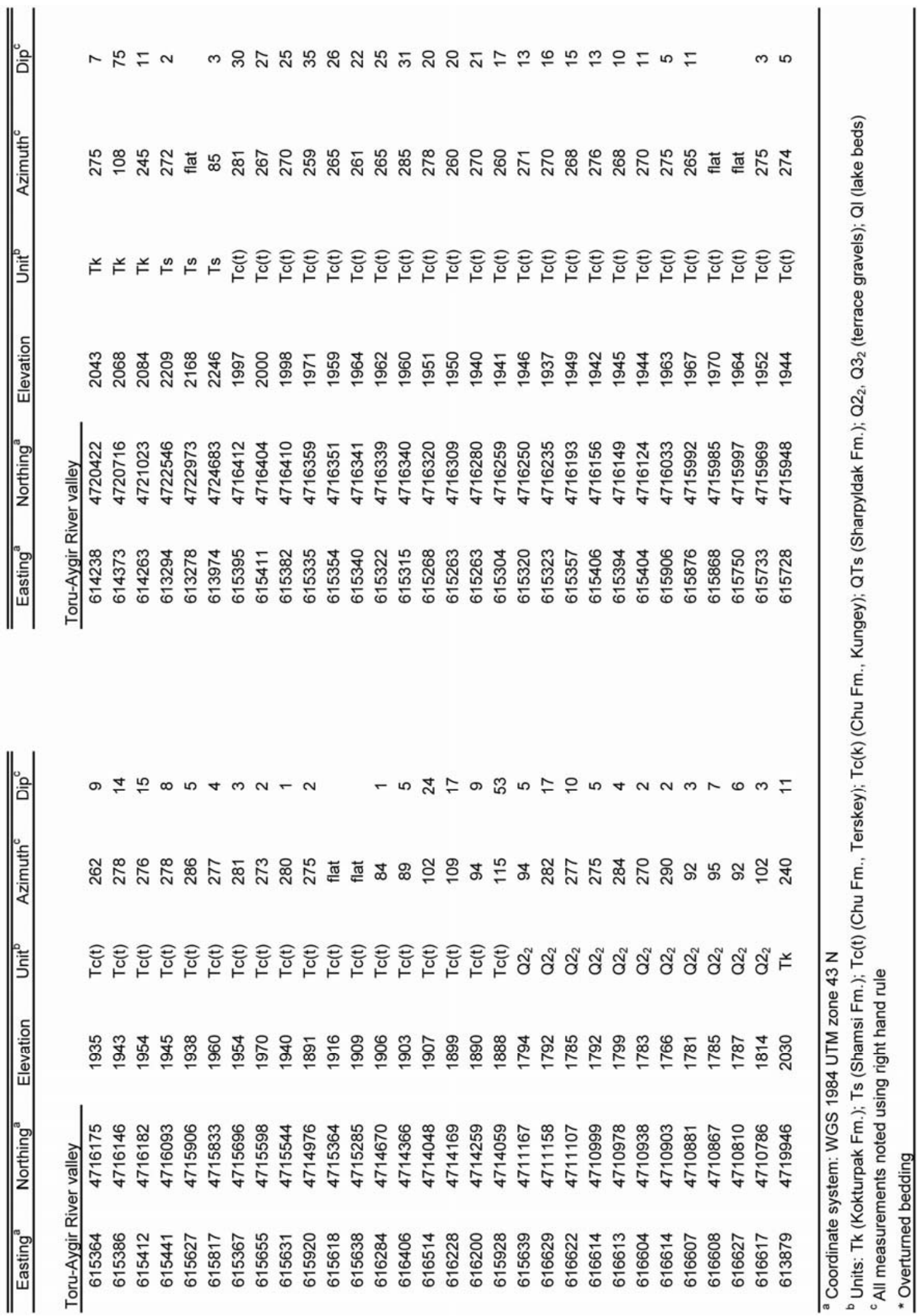




\section{Appendix B (continued)}

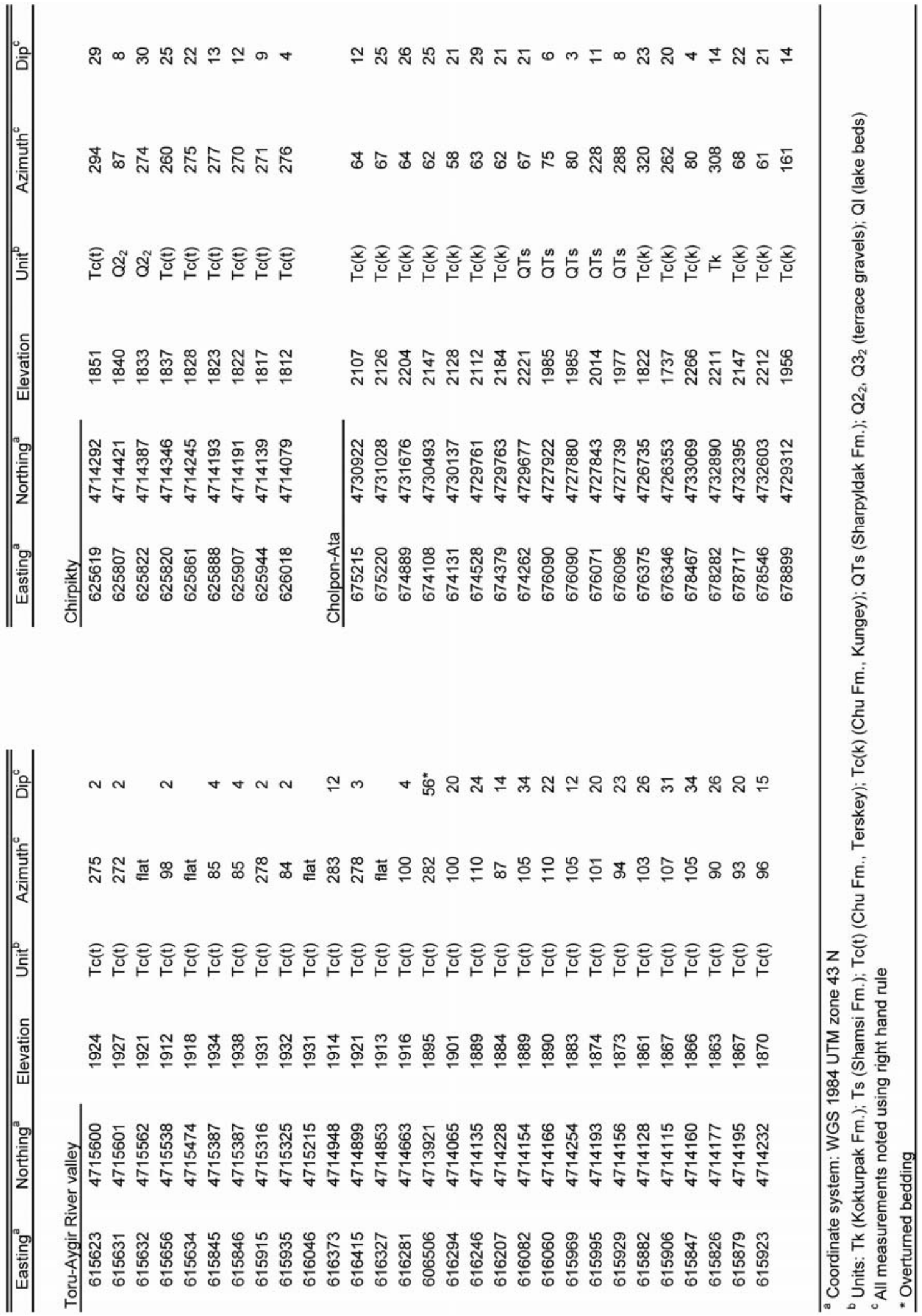




\section{Appendix B (continued)}

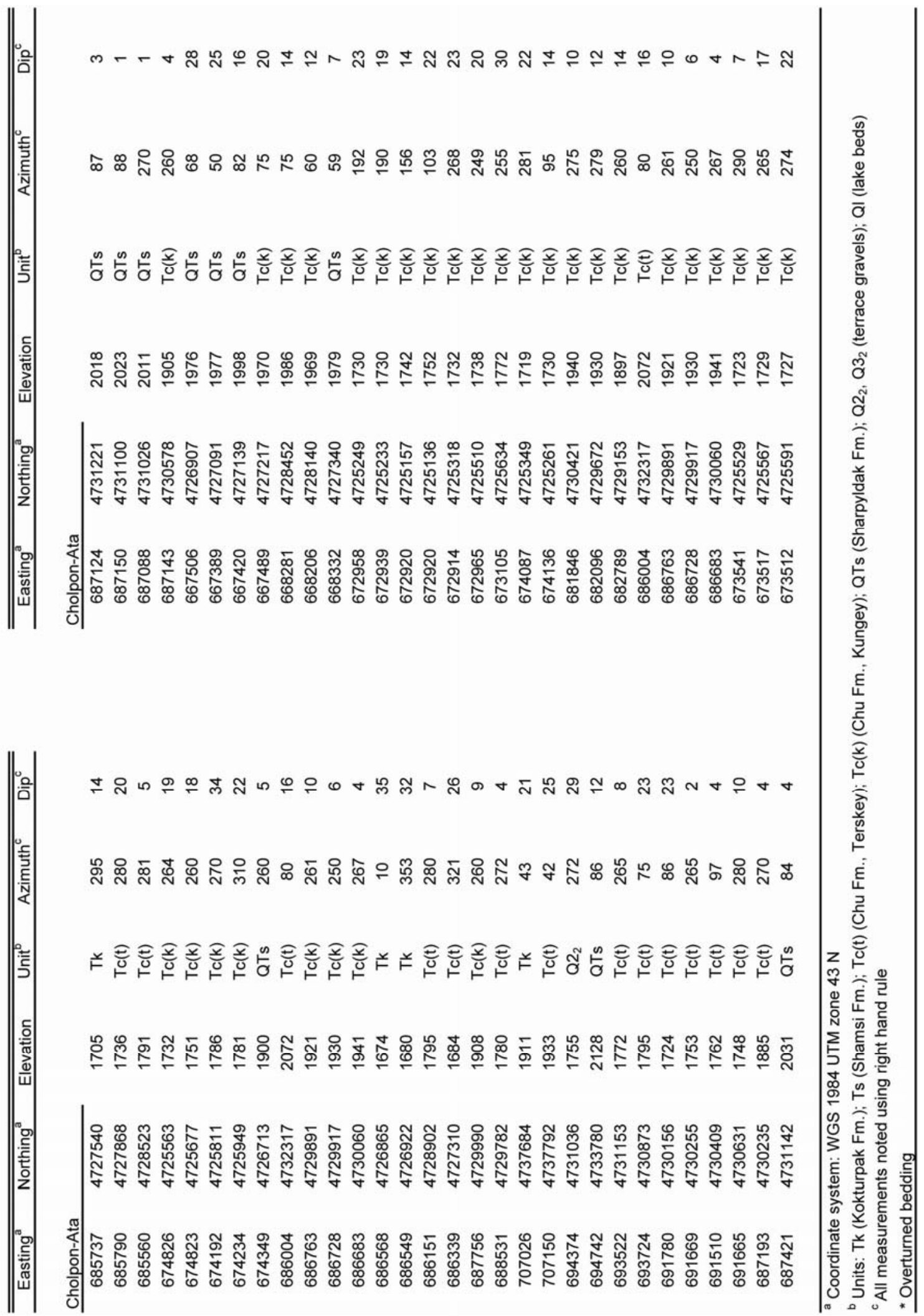




\section{Appendix B (continued)}

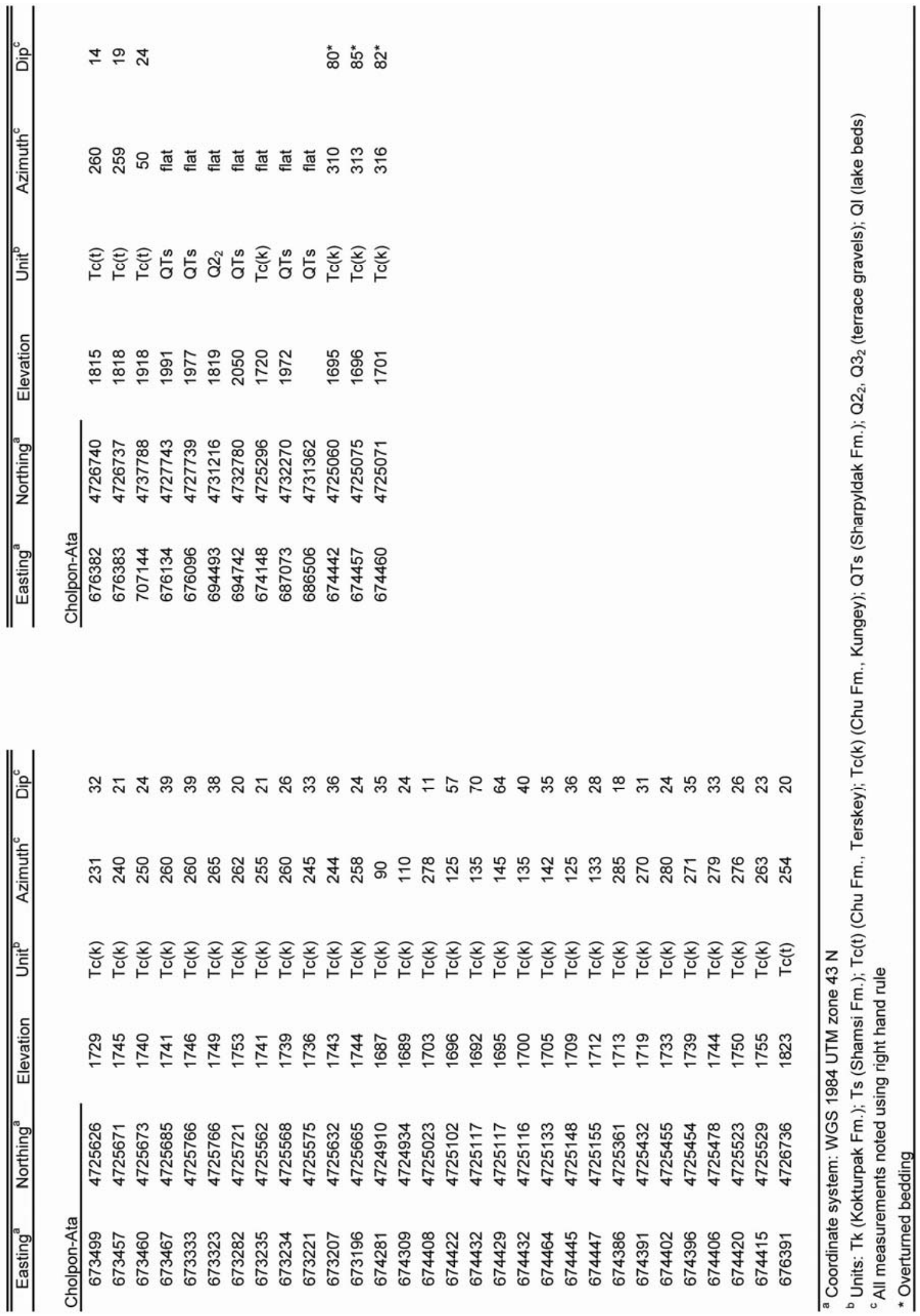




\section{References cited:}

Abdrakhmatov, K.Y., et al. (1996), Relatively recent construction of the Tien Shan inferred from GPS measurements of present-day crustal deformation rates, Nature, 384, 450-453.

Abdrakhmatov, K.Y., Weldon, R.J., Thompson, S., Burbank, D.W., Rubin, C., Miller, M., and Molnar, P. (2001), Onset, style and current rate of shortening in the central Tien Shan, Kyrgyz Republic, Russian Geology and Geophysics, 42 (10), 1585-1609.

Allen, M.B., Blanc, E.J-P., Walker, R., Jackson, J., Talebian, M., and Ghassemi, M.R. (2006) Contrasting styles of convergence in the Arabia-Eurasia collision: Why escape tectonics does not occur in Iran, GSA Special Paper, 409, 579-589.

Allen, M.B., and Vincent, S.J. (1997), Fault reactivation in the Junggar region, Northwest China; the role of basement structures during Mesozoic-Cenozoic compression, Journal of the Geological Society of London, 154, 151-155.

Allmendinger, R.W. (1998), Inverse and forward numerical modeling of trishear faultpropagation folds, Tectonics, 17 (4), 640-656.

Anderson, E.M. (1951), The dynamics of faulting and dyke formation with applications to Britain: Oliver \& Boyd, Edinburgh, 206 p.

Anderson, R.S., Repka, J.L., and Dick, G.S. (1997), Explicit treatment of inheritance in dating depositional surfaces using in situ ${ }^{10} \mathrm{Be}$ and ${ }^{26} \mathrm{Al}$, Geology, 24 (1), 47-51.

Arrowsmith, J.R., Crosby, C.J., Korjenkov, A.M., Mamyrov, E. and Povolotskaya, I.E. (2004), Surface rupture along the Chon Aksu and Aksu (eastern) segments of the 1911 Kebin (ChonKemin) earthquake, Tien Shan, Kyrgyzstan, Eos Trans. AGU, 85 (52), Abstract T14C-02.

Avouac, J.P., Tapponnier, P., Bai, M., You, H., and Wang, G. (1993), Active thrusting and folding along the northern Tien Shan and late Cenozoic rotation of the Tarim relative to Dzungaria and Kazakhstan, Journal of Geophysical Research, 98 (B4), 6755-6804.

Bazhenov, M.L., Burtman, V.S., Cobbold, P.R., Perroud, E., Sadybakasov, I., Thomas, J.C., and Chauvin, A. (1994), Paleomagnetism of Tertiary deposits and alpine kinematics of Tien Shan, Geotectonics, 27 (6), 492-504.

Bowman, D., King, G., and Tapponnier, P. (2003), Slip partitioning by elastoplastic propagation of oblique slip at depth, Science, 300, 1121-1123.

Bowman, D., Korjenkov, A., Porat, N., and Czassny, B. (2004), Morphological response to Quaternary deformation at an intermontane basin piedmont, the northern Tien Shan, Kyrgyzstan, Geomorphology, 63, 1-24. 
Brown, E.T., Brook, E.J., Raisbeck, G.M., Yiou, F., and Kurz, M.D. (1992), Effective attenuation lengths of cosmic rays producing 10Be and 26Al in quartz: Implications for exposure age dating, Geophysical Research Letters, 19 (4), 369-372.

Bullen, M.E., Burbank, D.W., Garver, J.I., and Abdrakhmatov, K.Y. (2001), Late Cenozoic tectonic evolution of the northwestern Tien Shan: New age estimates for the initiation of mountain building, GSA Bulletin, 113 (12), 1544-1559.

Bullen, M.E., Burbank, D.W., Garver, J.I. (2003), Building the northern Tien Shan: integrated thermal, structural, and topographic constraints, Journal of Geology, 111, 149-165.

Bump, A. (2003), Reactivation, trishear modeling, and folded basement in Laramide uplifts: Implications for the origins of intracontinental faults, GSA Today, 13 (3), 4-10.

Burbank, D.W., McLean, J.K., Bullen, M., Abdrakhmatov, K.Y., and Miller, M.M. (1999), Partitioning of intermontane basins by thrust-related folding, Tien Shan, Kyrgyzstan, Basin Research, 11 (1), 75-92.

Burchfiel, B.C. et al. (1999), Crustal shortening on the margins of the Tien Shan, Xinjiang, China, International Geology Review, 41, 665-700.

Buslov, M.M. et al. (2003), Recent strike-slip deformation of the northern Tien Shan, in Intraplate Strike-Slip Deformation Belts, edited by F. Storti, R.E. Holdsworth, and F. Salvini, Geological Society of London special publications, 210, 53-64.

Burtman, V.S. (1975), Structural geology of the Variscan Tien Shan, USSR, American Journal of Science, 275, 157-186.

Burtman, V.S., Skobolev, S.F., and Molar, P. (1996), Late Cenozoic slip on the Talas-Ferghana fault, the Tien Shan, central Asia, GSA Bulletin, 108, 1004-1021.

Butler, R.W., Tavarnelli, E., and Grasso, M. (2006), Structural inheritance in mountain belts; an Alpine-Apennine perspective, Journal of Structural Geology, 28 (11), 1893-1908.

Carroll, A.R., Graham, S.A., Chang, E.Z., and McKnight, C. (2001), Sinian through Permian tectonostratigraphic evolution of the northwestern Tarim Basin, China, GSA Memoir, 194, 4769.

Cerling, T.E. and Craig, H. (1994), Geomorphology and in-situ cosmogenic isotopes, Annual Reviews of Earth Planetary Science, 22, 273-317.

Chapple, W.M. (1978), Mechanics of thin-skinned fold-and-thrust belts, GSA Bulletin, 89, 1189-1198.

Chediya, O.K. (1986), Morphology and neotectonics of the Tien Shan (in Russian), Ilim, Bishkek, Kyrgyzstan, 313 p. 
Chevalier, M.L., Ryerson, F.J., Tapponnier, P., Finkel, R.C., Van Der Woerd, J., Haibing, L. and Qing, L. (2005), Slip rate measurements on the Karakorum fault may imply secular variations in fault motion, Science, 307, 411-414.

Cobbold, P.R., Sadybakasov, E., and Thomas, J.C. (1994), Cenozoic transpression and basin development, Kyrgyz Tien Shan, central Asia, Geodynamic evolution of sedimentary basins, International Symposium, 181-202.

Cowgill, E., Yin, A. and Arrowsmith, J.R. (2003), Feedbacks between topographic growth and structural style within restraining double bends deduced from the Akato Tagh bend, Altyn Tagh fault, NW China, GSA Abstracts with Programs, 35 (6) p 304.

Cowgill, E. (2007), Impact of riser reconstructions on estimation of secular variation in rates of strike-slip faulting: Revisiting the Cherchen River site along the Altyn Tagh fault, NW China, Earth and Planetary Science Letters, 254, 239-255.

Cowie, P.A. and Scholz, C.H. (1992), Physical explanation for the displacement-length relationship of faults using a post-yield fracture mechanics model, Journal of Structural Geology, 14 (10), 1133-1148.

Crosby, C.J., Arrowsmith, J.R., Korjenkov, A.M., Mamyrov, E. and Povolotskaya, I. (2005), Surface rupture of the 1911 Kebin (Chon-Kemin) earthquake, northern Tien Shan, Kyrgyzstan, Eos Trans. AGU, 86 (52), Abstrace T51F-05.

Crosby, C.J., Arrowsmith, J.R., Korjenkov, A.M., Guralnik, B., Mamyrov, E. and Povolotskaya, I.E. (2007), The hunt for surface rupture from the 1889 Ms 8.3 Chilik earthquake, northern Tien Shan, Kyrgyzstan and Kazakhstan, Eos Trans. AGU, 88(52), Abstract T23D-1635.

Cunningham, W.D., Windley, B.F., Dorjnamjaa. D., Badamgarov, J. and Saandar, M. (1996), Late Cenozoic transpression in southwestern Mongolia and the Gobi Altai-Tien Shan connection, Earth and Planetary Science Letters, 140, 67-81.

D’Lemos, R.S., Schofield, D., Holdsworth, R.E. and King, T.R. (1997), Deep crustal and local rheological controls on the siting and reactivation of fault and shear zones, northeastern Newfoundland, in The role of basement reactivation in continental deformation, edited by $\mathrm{R}$. Butler, R. Holdsworth, and G. Lloyd, Journal of the Geological Society of London, 154, 117121. 
De Grave, J., Buslov, M.M., and Van den haute, P. (2007), Distant effects of India-Eurasia convergence and Mesozoic intracontinental deformation in Central Asia: Constraints from apatite fission-track thermochronology, Journal of Asian Earth Sciences, 29, 188-204.

Darby, B.J. and Ritts, B.D. (2002), Mesozoic contractional deformation in the middle of the Asian tectonic collage; the intraplate western Ordos fold-thrust belt, China, Earth and Planetary Science Letters, 205 (1-2), 13-24.

Davis, D., Suppe, J. and Dahlen, F.A. (1983), Mechanics of fold-and-thrust belts and accretionary wedges, Journal of Geophysical Research, 88 (B2), 1153-1172.

Delvaux, D.F., Abdrakhmatov, K.Y., Strom, A.L., and Havenith, H.B. (1999), Surface break and landslides related to the M 8.2, 1911 Kemin earthquake along the Chon-Kemin-Chilik active sinistral transpression zone in the northern Tian Shan, Eos Trans. AGU, 80 (52), Abstract T41E-04.

Delvaux, D., Abdrakhmatov, K.Y., Lemzin, I.N. and Strom, A.L. (2001), Landslides and surface breaks of the 1911 M 8.2 Kemin earthquake, Russian Geology and Geophysics, 42 (10), 1583-1592.

Ding, G., Chen, J., Qinjian, T., Xuhui, S., Chenggi, X., and Kaibo, W. (2004), Active faults and magnitudes of left-lateral displacement along the northern margin of the Tibetan Plateau, Tectonophysics, 380 (3-4), 243-260.

Dumitru, T.A., Zhou, D., Chang, E.Z., Graham, S.A., Hendrix, M.S., Sobel, E.R., and Carroll, A.R. (2001), Uplift, exhumation, and deformation in the Chinese Tian Shan, GSA Memoir, 194, 71-99.

England, P. and Molnar, P. (1997a), Active deformation of Asia: From kinematics to dynamics, Science, 278, 647-650.

England, P. and Molnar, P. (1997b), The field of crustal velocity in Asia calculated from Quaternary rates of slip on faults, Geophysical Journal International, 130, 551-582.

Erslev, E.A. (1986), Basement balancing of Rocky Mountain foreland uplifts, Geology, 14, 259-262.

Erslev, E.A. (1991), Trishear fault-propagation folding, Geology, 19, 617-620.

Grigorienko, P.G. (1970), The main features of geological development of Kyrgyz Tien Shan during the Quaternary Period (in Russian), in Materials about Cenozoic Geology and the Newest Tectonics of the Tien Shan, Ilimk, Bishkek, Kyrgyzstan, 3-11.

Heermance, R.V., Chen, J., Burbank, D.W., and Wang, C. (2007), Chronology and tectonic controls of late Tertiary deposition in the southwestern Tian Shan foreland, NW China, Basin Research, 19 (4), 599-632. 
Hendrix, M.S., Dumitru, T.A., and Graham, S.A. (1994), Late Oligocene-early Miocene unroofing in the Chinese Tian Shan; and early effect of the India-Asia collision, Geology, 22 (6), 487-490.

Hilley, G.E., Blisniuk, P.M., and Strecker, M.R. (2005), Mechanics and erosion of basementcored uplift provinces, Journal of Geophysical Research, 110, B12409.

Holdsworth, R.E., Butler, C.A., and Roberts, A.M. (1997), The recognition of reactivation during continental deformation, Journal of the Geological Society of London, 154 (1), 73-78.

Holm, R.F. and Cloud, R.A. (1990), Regional significance of recurrent faulting and intracanyon volcanism at Oak Creek canyon, southern Colorado Plateau, Arizona, Geology, 18 (10), 1014-1017.

Holt, W.E., Chomot-Rooke, N., Pichon, X.L., Haines, A.J., Shen-Tu, B., and Ren, J. (2000), Velocity field in Asia inferred from late Quaternary fault slip rates and Global Positioning System observations, Journal of Geophysical Research, 105 (B8), 19185-19209.

Hubbert, M.K. and Rubey, W.W. (1959), Roles of fluid pressure in mechanics of overthrust faulting, Bulletin of the Geological Society of America, 70, 115-166.

Johnston, R.E. and Yin, A. (2001), Kinematics of the Uinta fault system (Southern Wyoming and Northern Utah) during the Laramide Orogeny, International Geology Review, 43, 52-68.

Jordan, T.E. and Allmendinger, R.W. (1986), The Sierras Pampeanas of Argentina, a modern analogue of Rocky Mountain foreland deformation, American Journal of Science, 286 (10), 737-764.

Kirby, E., Harkins, N., Erqi, W., Xuhua, S., Chun, F., and Burbank, D. (2007), Slip rate gradients along the eastern Kunlun fault, Tectonics, 26 (2), 414-428.

Korjenkov, A.M. (2000), Cenozoic tectonics and seismicity of the northwest Issyk-Kul basin, Tien Shan, Russian Geology and Geophysics, 41 (7), 940-950.

Korjenkov, A.M., Povolotskaya, I.E., and Mamurov, E. (2007), Morphologic expression of Quaternary deformation in the northwestern foothills of the Issyk-Kul basin, Tien Shan, Geotectonics, 41 (2), 130-148.

Lacassin, R. et al. (2004), Large scale geometry, offset and kinematic evolution of the Karakorum fault, Tibet, Earth and Planetary Science Letters, 219, 255-269.

Larson, K.M., Buergmann, R., Bilham, R. and Freymueller, J.T. (1999), Kinematics of the India-Eurasia collision zone from GPS measurements, Journal of Geophysical Research, 104 (B1), 1077-1093. 
Lal, D. (1988), In situ-produced cosmogenic isotopes in terrestrial rocks, Annual Reviews of Earth Planetary Science, 16, 355-388.

Lal, D. (1991), Cosmic ray labeling of erosion surfaces: in-situ nuclide production rates and erosion models, Earth and Planetary Science Letters, 104, 424-439.

Lave, J. and Avouac, J.P. (2000), Active folding of fluvial terraces across the Siwaliks Hills, Himalayas of central Nepal, Journal of Geophysical Research, 105 (B3), 5735-5770.

Makarov, V.I. (1977), New tectonic structures of the central Tien Shan (in Russian), Order of the Red Banner Geology Institute, Academy of Science, Moscow, 171 p.

Meade, B.J. and Hager, B.H. (2001), The current distribution of deformation in the western Tien Shan from block models constrained by geodetic data, Russian Geology and Geophysics, 42 (10), 1622-1633.

Michael, A.J. (1990), Energy constraints on kinematic models of oblique faulting; Loma Prieta versus Parkfield-Coalinga, Geophysical Research Letters, 17 (9), 1453-1456.

Mikolaichuk, A.V. (2000), The structural position of thrusts in the recent orogen of the central Tien Shan, Russian Geology and Geophysics, 41 (7), 929-939.

Mikolaichuk, A.V., Gubrenko, M.V., and Bogomolov, L.M. (2003), Fold deformations of a preorogenic peneplain in the recent structure of the central Tien Shan, Geotectonics, 37 (1), 3642.

Molnar, P. (1992), Brace-Goetze strength profiles, the partitioning of strike-slip faulting and thrust faulting at zones of oblique convergence, and the stress-heat fow paradox of the San Andreas fault, in Fault Mechanics and Transport Properties of Rocks, edited by B. Evans and T. Wong, 435-460.

Molnar, P. et al. (1994), Quaternary climate change and the formation of river terraces across growing anticlines on the north flank of the Tien Shan, China, Journal of Geology, 102, 583602.

Molnar, P. and Ghose, S. (2000), Seismic moments of major earthquakes and the rate of shortening across the Tien Shan, Geophysical Research Letters, 27 (16), 2377-2380.

Molnar, P. and Tapponnier, P. (1975), Cenozoic tectonics of Asia: Effects of a continental collision, Science, 189, 419-426.

Mossakovsky, A.A., Ruzhentsev, S.V., Samygi,, S.G., and Kheraskova, T.N. (1994), Central Asian fold belt; geodynamic evolution and formation history, Geotectonics, 27 (6), 445-474. 
Mouthereau, F. and Lacombe, O. (2006), Inversion of the Paleogene Chinese continental margin and thick-skinned deformation in the western foreland of Taiwan, Journal of Structural Geology, 28, 1977-1993.

Narr, W. and Suppe, J. (1994), Kinematics of basement-involved compressive structures, American Journal of Science, 294, 802-860.

Okada, Y. (1985), Surface deformation due to shear and tensile faults in a half-space, Bulletin of the Seismological Society of America, 75 (4), 1135-1154.

Oskin, M.E. and Burbank, D.W. (2005), Alpine landscape evolution dominated by cirque retreat, Geology, 33 (12), 933-936.

Oskin, M.E. and Burbank, D.W. (2007), Transient landscape evolution of basement-cored uplifts: Example of the Kyrgyz Range, Tian Shan, Journal of Geophysical Research, 112 (F3).

Perg, L.A., Anderson, R.S. and Finkel, R.C. (2001), Use of a new ${ }^{10} \mathrm{Be}$ and ${ }^{26} \mathrm{Al}$ inventory method to date marine terraces, Santa Cruz, California, USA, Geology, 29 (10), 879-882.

Pigati, J.S. and Lifton, N.A. (2004), Geomagnetic effects on time-integrated cosmogenic nuclide production with emphasis on in situ 14C and 10Be, Earth and Planetary Science Letters, 226 (1-2), 193-205.

Povolotskaya, I.E., Korjenkov, A.M. and Mamurov, E.M. (2007), Signature of large earthquakes in lacustrine deposits of the Kok-Moynok basin, Russian Geology and Geophysics, 47 (9), 1024-1035.

Reigber, C. et al. (2001), New space geodetic constraints on the distribution of deformation in central Asia, Earth and Planetary Science Letters, 191 (1-2), 157-165.

Repka, J.L., Anderson, R.S. and Finkel, R.C. (1997), Cosmogenic dating of fluvial terraces, Fremont River, Utah, Earth and Planetary Science Letters, 152 (1-4), 59-73.

Rogers, J.W. (1987), Chains of basement uplifts within cratons marginal to orogenic belts, American Journal of Science, 287 (7), 661-692.

Sadybakasov, I. (1990), Neotectonics of High Asia (in Russian), Nauka, Moscow, 176 p.

Scharer, K.M., Burbank, D.W., Chen, J., Weldon, R.J., Rubin, C., Zhao, R. and Shen, J. (2004), Detachment folding in the southwestern Tian Shan-Tarim foreland, China: Shortening estimates and rates, Journal of Structural Geology, 26, 2119-2137.

Scholz, C.H. (2002), The Mechanics of Earthquakes and Faulting, Caimbridge, 471 p.

Sengor, A.M., Natal'in, B.A. and Burtman, V.S. (1993), Evolution of the Altaid tectonic collage and Paleozoic crustal growth in Eurasia, Nature, 364, 299-307. 
Sibson, R.H. (1985), A note on fault reactivation, Journal of Structural Geology, 7 (6), 751 754.

Small, E.E., Anderson, R.S., Repka, J.L. and Finkel, R. (1997), Erosion rates of alpine bedrock summit surfaces deduced from in situ ${ }^{10} \mathrm{Be}$ and ${ }^{26} \mathrm{Al}$, Earth and Planetary Science Letters, 150, 413-425.

Sobel, E.R. and Dumitru, T.A. (1997), Thrusting and exhumation around the margins of the western Tarim Basin during the India-Eurasia collision, Journal of Geophysical Research, 102 (B3), 5043-5063.

Sobel, E.R. and Arnaud, N. (2000), Cretaceous-Paleogene basaltic rocks of the Tuyon basin, NW China and the Kyrgyz Tian Shan: the trace of a small plume, Lithos, 50, 191-205.

Sobel, E.R., Oskin, M.E., Burbank, D.W. and Mikolaichuk, A. (2006) Exhumation of basement-cored uplifts: Example of the Kyrgyz Range quantified with apatite fission-track thermochronology, Tectonics, 25 (2).

Suppe, J. (1983), Geometry and kinematics of fault-bend folding, American Journal of Science, 283, 684-721.

Suppe, J. and Medwedeff, D.A. (1990), Geometry and kinematics of fault-propagation folding, Eclogae Geologicae Helvetiae, 83 (3), 409-454.

Tapponnier, P. and Molnar, P. (1979), Active faulting and Cenozoic tectonics of the Tien Shan, Mongolia, and Baykal regions, Journal of Geophysical Research, 84 (B7), 3425-3459.

Thomas, J.C., Perroud, H., Cobbold, P.R., Bazhenov, M.L., Burtman, V.S., Chauvin, A. and Sadybakasov, E. (1993), A paleomagnetic study of Tertiary formations from the Kyrgyz Tien Shan and its tectonic implications, Journal of Geophysical Research, 98 (B6), 9571-9589.

Thompson, S.C., Weldon, R.J., Rubin, C.M., Abdrakhmatov, K.Y., Molnar, P. and Berger, G. (2002), Late Quaternary slip rates across the central Tien Shan, Kyrgyzstan, central Asia. Journal of Geophysical Research, 107 (B9).

Tibaldi, A., Graziotto, E., Forcella, F. and Gapich, V.H. (1997), Morphotectonic indicators of Holocene faulting in central Tien Shan, Kazakhstan, and geodynamic implications, Journal of Geodynamics, 23 (1), 23-45.

Vassallo, R. et al. (2007), Transpressional tectonics and stream terraces of the Gobi-Altay, Mongolia, Tectonics, 26, TC5013.

Webb, L.E. and Johnson, C.L. (2006), Tertiary strike-slip faulting in southeastern Mongolia and implications for Asian tectonics, Earth and Planetary Science Letters, 241 (1-2), 323-335. 
Weldon, R.J. and Sieh, K.E. (1985), Holocene rate of slip and tentative recurrence interval for large earthquakes on the San Andreas fault, Cajon pass, southern California, GSA Bulletin, 96, 793-812.

Windley, B.F., Alexeiev, D., Wenjiao, X., Kroener, A., and Badarch, G. (2007), Tectonic models for accretion of the Central Asian orogenic belt, Journal of the Geological Society of London, 164 (1), 31-47.

Yin, A., Nie, S., Craig, P., Harrison, T.M., Ryerson, F.J., Xianglin, Q. and Geng, Y. (1998), Late Cenozoic tectonic evolution of the southern Chinese Tien Shan, Tectonics, 17 (1), 1-27.

Zubovich, A.V., Trapeznikov, Y.A., Bragin, B.D., Mosienko, O.I., Shchelochkov, G.G., Rybin, A.K., and Batalev, V.Y. (2001), Deformation field, deep crustal structure, and spatial seismicity distribution in the Tien Shan, Russian Geology and Geophysics, 42 (10), 1550-1557. 

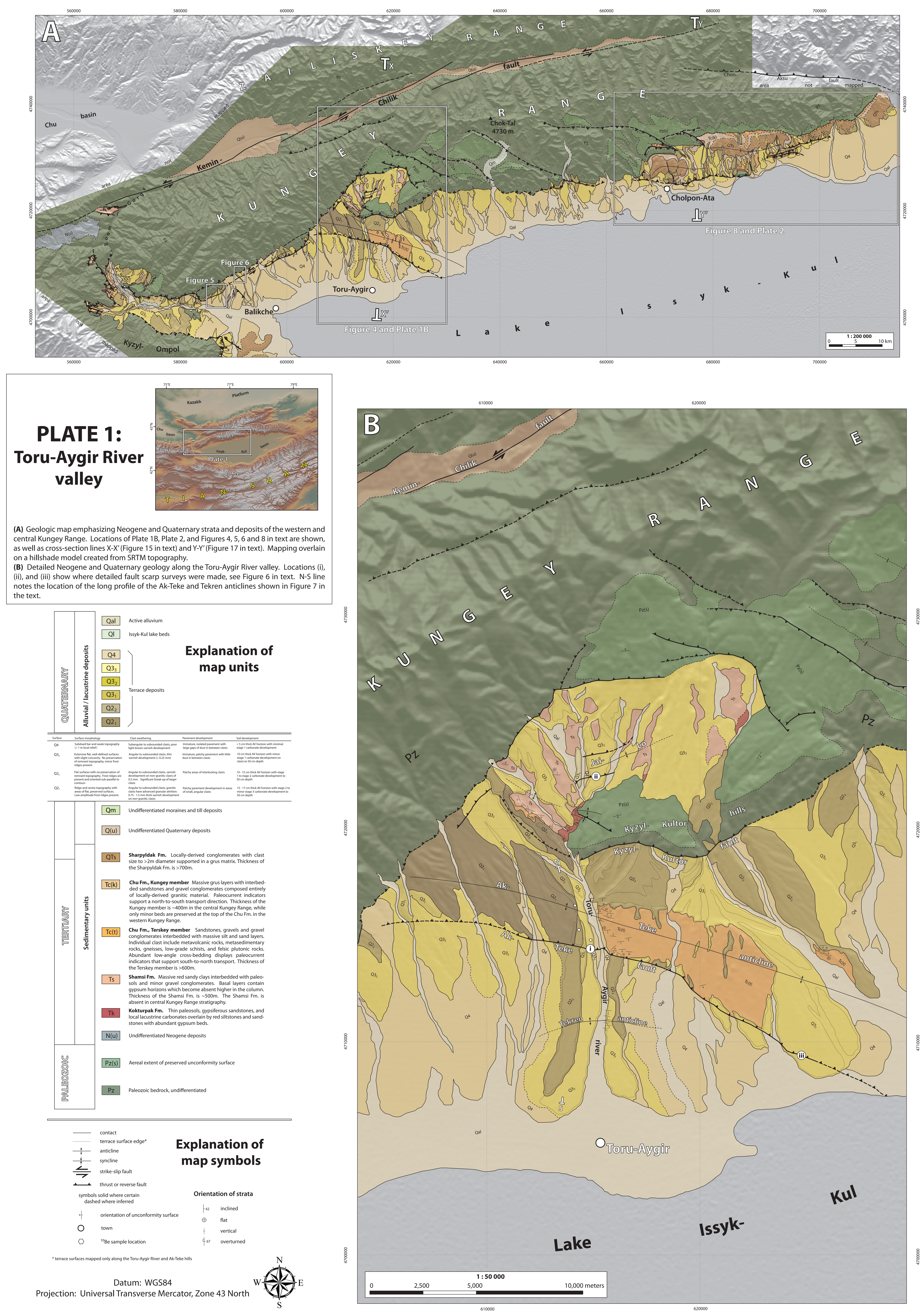

Datum: WGS84
Projection: Universal Transverse Mercator, Zone 43 North 

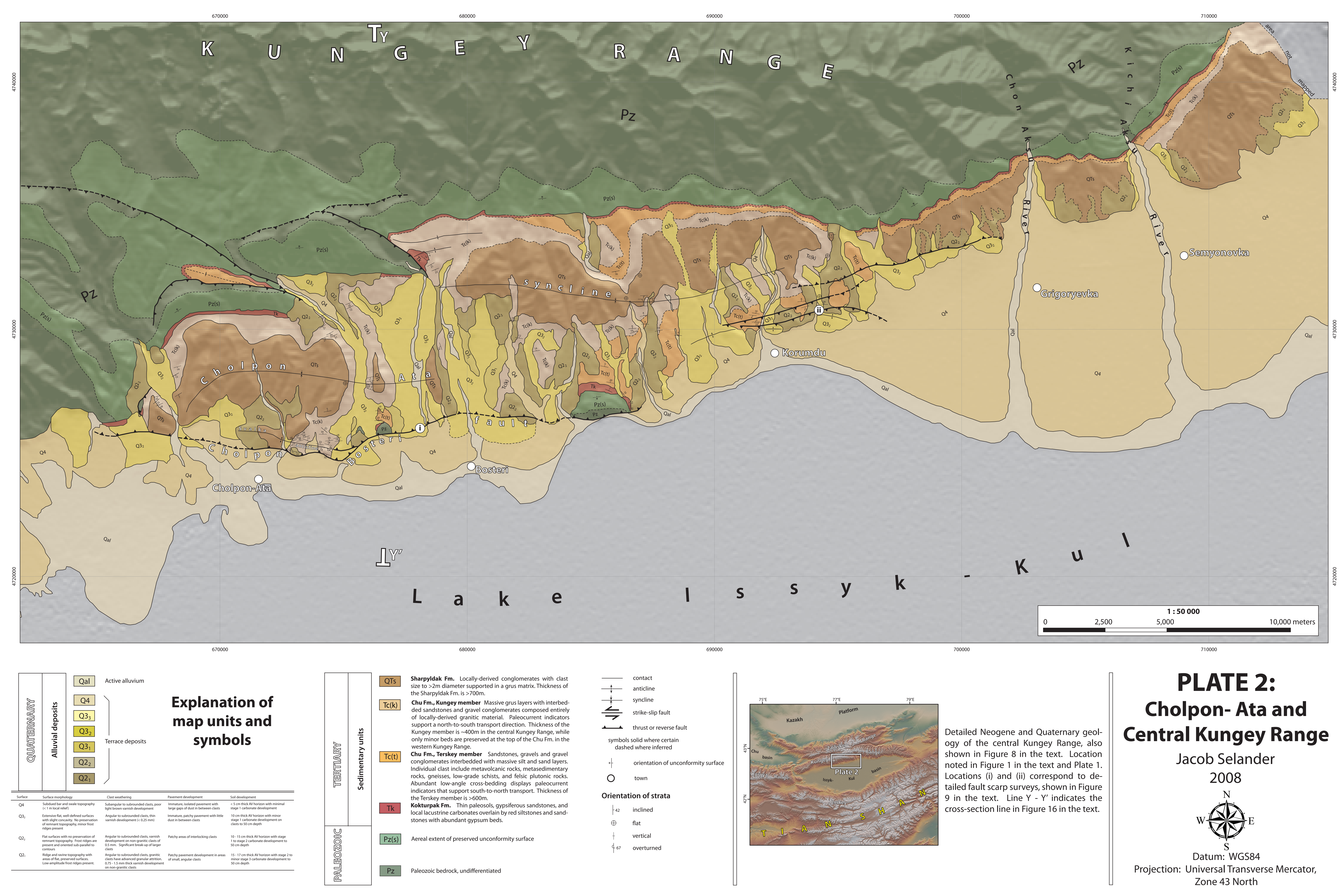

PLATE 2:

Cholpon- Ata and Central Kungey Range Jacob Selander 2008 shown in Figurtral Kungey Range, alto noted in Figure 1 in the text and Plate 1 . Locations (i) and (ii) correspond to de-
tailed fault scarp surveys, shown in Figure in the text. Line Y Y - Y' indicates the
coss-section line in Figure 16 in the text. 